\title{
CISG THROUGH THE WILLEM C VIS MOOT CASEBOOK - SEVENTEEN YEARS OF THE CISG EVOLUTION EXPLORED THROUGH ANNUAL GLOBAL DISCUSSION
}

\author{
By \\ Ana Barbara Baide
}

\begin{abstract}
A dissertation
submitted to the Victoria University of Wellington in partial fulfilment of the requirements for the degree of Master of Laws
\end{abstract}

Victoria University of Wellington 2009 


\section{ABSTRACT}

This paper explores the evolution of the United Nations Convention on the International Sale of Goods (referred to throughout the text as the "CISG" or the "Convention") jurisprudence through the Willem C Vis Moot ("Vis Moot") casebook. It analyses the CISG issues raised and explored in the seventeen years of the Willem C Vis Moot and draws out notable trends and key themes. Upon the analysis of the trends and themes which have arisen over the past seventeen years, the dissertation discusses how the Vis Moot problems, as well as the winning memoranda, reflect and encapsulate the evolution and developments in the worldwide application and interpretation of the CISG in those areas. The analysis of the Vis Moot problems is thus used as a tool to consider the worldwide jurisprudential developments on the CISG over the past two decades, and identify both those aspects of the Convention that have benefited from considerable analysis, and where comprehensive jurisprudence has already developed, as well as the "gap" areas where further work is required in order to ensure the CISG evolves alongside technological, social, political and legal developments affecting international sale of goods contracts. The dissertation concludes by drawing out the notable trends illustrated by, and set against the backdrop of, the Vis Moot casebook, and the consequent implications of such trends on the current state of CISG jurisprudence. In particular, these trends and outcomes are assessed as against the overall spirit of the Convention and its goal of achieving, or seeking to achieve, uniform application of rules on international sale of goods contracts. This assessment seeks to capture how this goal of uniformity has been achieved to-date, and where the upcoming challenges may lie in the coming years. Finally, the paper considers the overall importance and impact of the Vis Moot, as an annual global event with manifold benefits, on the interpretation, promotion and development of the CISG. 


\section{ACKNOWLEDGMENTS}

First and foremost I would like to express my gratitude to my supervisor, Dr. Petra Butler. Dr. Petra Butler has been a key influence in my legal career and a pillar of support and guidance. She has been an inspiring mentor, both during the preparation and writing of this dissertation, and also during the years since my initial involvement with the Willem C Vis Moot as a participant in the eleventh year of the competition. Her enthusiasm for the CISG, international commercial arbitration and the Willem C Vis Moot, and her vast knowledge in these areas, has captured the attention of many students over the years, including myself. Consequently, my interest in these topics has never faded. Without Petra's ongoing support, guidance and passion this dissertation may not have come to fruition.

I would like to thank Professor Eric E. Bergsten of Pace Law School, as well as Akad. Rat Dr. Ulrich G. Schroeter and Moritz Schmitt of Albert-Ludwigs-Universität Freiburg for their kind assistance with my attempts to source the student memoranda from the first four years of the Willem C Vis Moot.

I extend special thanks to past and present participants at the Willem C Vis Moot. In particular, I would like to acknowledge the teams of Victoria University of Wellington and University of Osnabrück with whom I have been directly involved. I would also like to extend my appreciation to many other teams that I have come across over the years whose diligence, mooting skills and friendships have maintained my interest in, and enthusiasm for, this topic.

I would like to acknowledge the support of Russell McVeagh during my time with them and the writing of this dissertation.

Many thanks go to my family, who have supported me unconditionally over the years, as well as my friends for their ongoing encouragement and patience with proof reading.

Finally, I would like to acknowledge the assistance of Jonathan Dempsey and the Victoria University Law Faculty. 


\section{CONTENTS}

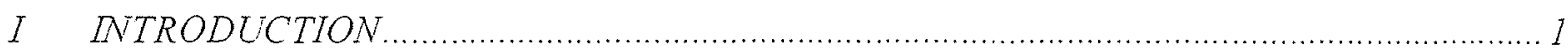

Relevance of the Vis Moot fact scenarios ...................................................................... 1

II CISG - BACKGROUND .AND STRUCTURE OF THE TEXT .......................................

A Background - Touards a uniform law of international sales...................................t

B Text and Structure of the CISG - An Outline ........................................................... 6

III IIS MOOT AS THE MIRROR TO THE EVOLUTION OF THE CISG …............................

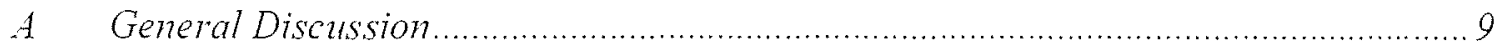

1 Evolution of the Vis Moot Problems ................................................................ 9

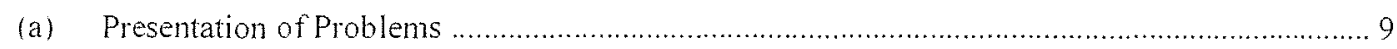

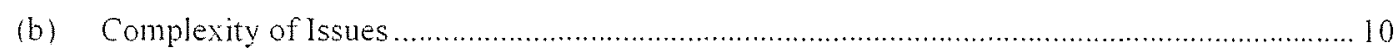

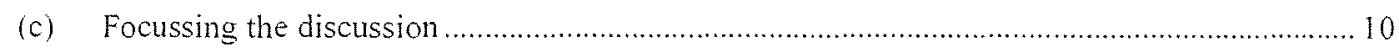

2 Growth in CISG resources vis-à-1is the evolution of the Vis Moot................ I1

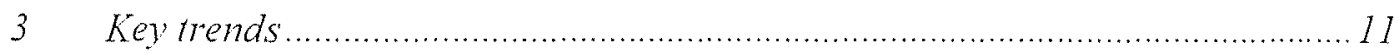

B Analysis of Key Trends and Issues.................................................................. It

$1 \quad$ Interpreting parties' intentions - Article 8 ................................................. It

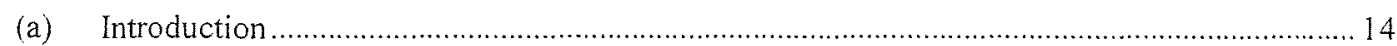

(b) Subjective approach - Intent - Article 8(1) ………............................................................ 15

(c) Objective approach - reasonable person in the same type of business - Article 8(2),.............. 17

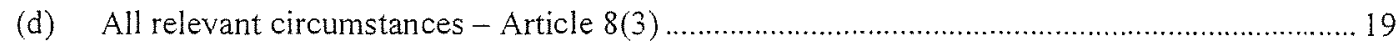

(e) Article 8(3) and the Parol Evidence Rule ………...................................................................23

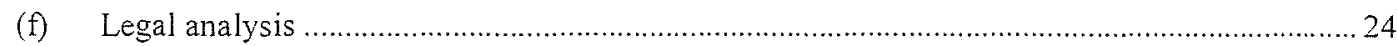

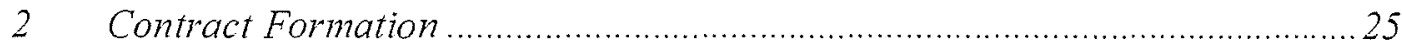

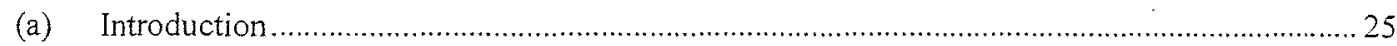


(b) Sufficiently Definite Offer \& Agreement on Price - Article 14 .........................................26

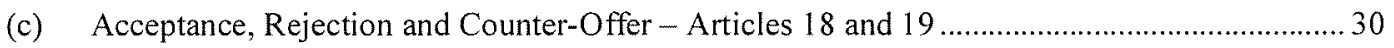

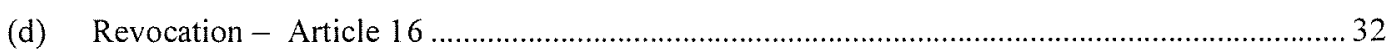

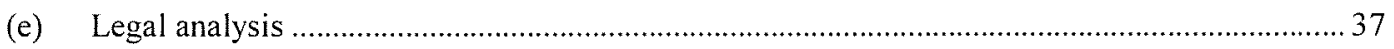

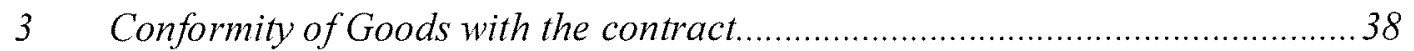

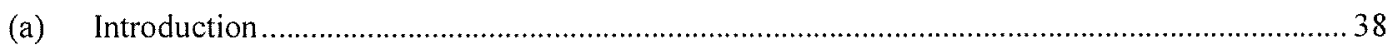

(b) Immaterial discrepancies as a type of non-conformity ..................................................... 40

(c) General exploration of the interoperability of paragraphs 1 and 2 of Article $35 \ldots \ldots \ldots \ldots \ldots \ldots . . . .44$

(d) Specific issues arising under paragraphs (a) and (b) of Article 35(2).................................45

(e) Quality standards in the buyer's jurisdiction \& requirements of Article 35(2) .....................46

(f) Public allegations impacting merchantability of the goods - from the Mussels case to the

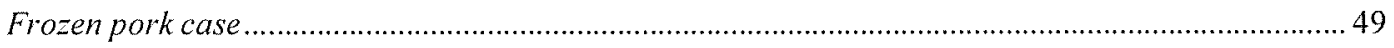

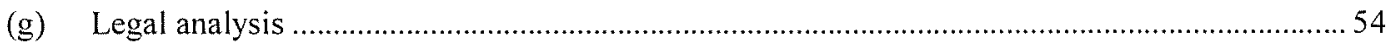

$4 \quad$ Fundamental Breach as a precondition of Avoidance .....................................55

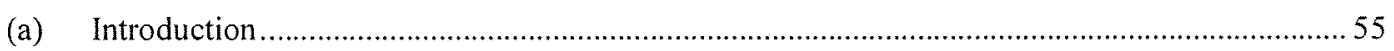

(b) Fundamental breach due to non-conformity of goods - general issues .................................58

(c) Fundamental breach due to defective goods \& seller's right to cure - interplay between Articles

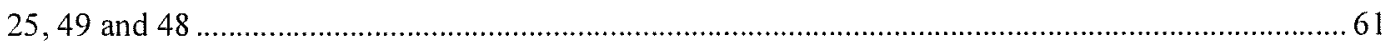

(d) Fundamental beach as a result of non-delivery, delays in, or partial delivery of goods ............65

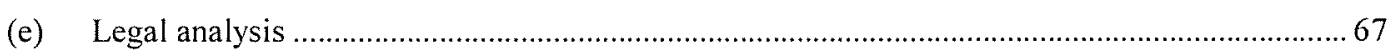

5 Exemptions - Article 79 "Force Majeure" ...........................................6 68

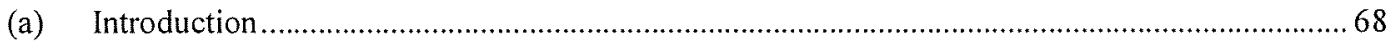

(b) Elements of Article 79 - Foreseeability and Ability to overcome the impediement..................70

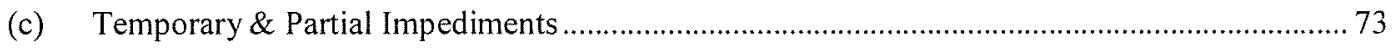

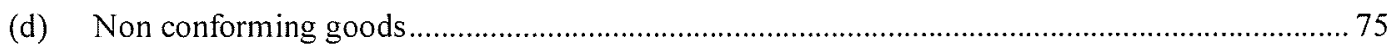

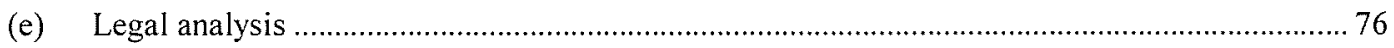

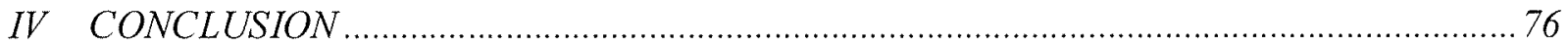




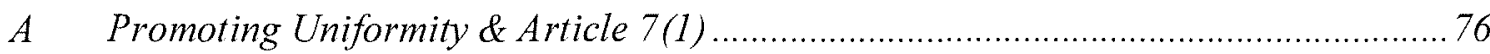

B Mapping Major Trends \& Jurisprudential Outcomes ............................................ 79

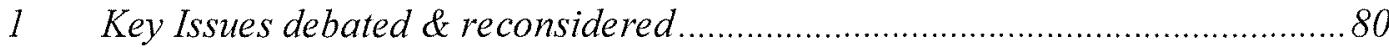

$2 \quad$ Summary of Key Themes

3 "Hot topics" and the seventeenth Vis Moot ...................................................84

C Educational Outcomes \& Overall Impact of the Vis Moot........................................85

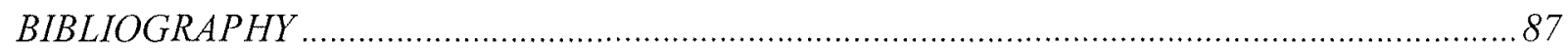

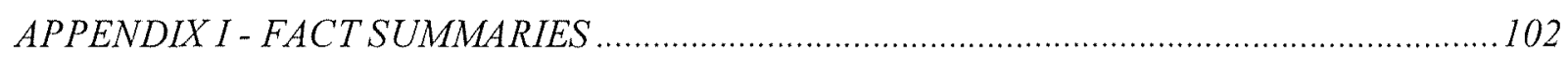

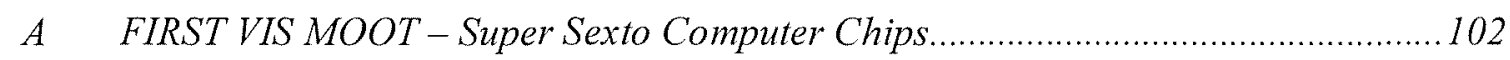

B SECOND VIS MOOT $-X-23$ mobile telecommunications base stations .................. 103

C THIRD VIS MOOT - 14C Air Conditioning Units .................................................. 104

D FOURTH VIS MOOT - Men's Suits ................................................................ 106

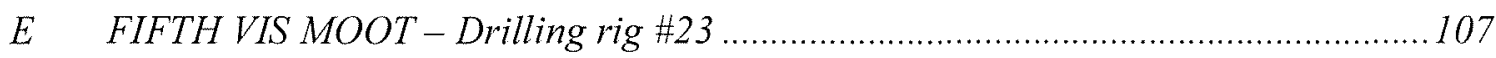

F SIXTH VIS MOOT - Paper making control system ........................................... 108

G SEVENTH VIS MOOT - Standard feed wheat .................................................... 110

H EIGHTH VIS MOOT - Vis water sports equipment .........................................111

I NINTH VIS MOOT - Polyester yarn manufacturing line …................................113

J TENTH VIS MOOT-Oriented Polypropylene film .............................................. 114

K ELEVENTH VIS MOOT - Auger-feeder packaging machines ...............................115

L TWELFTH VIS MOOT - Cocoa beans.............................................................. 116

M THIRTEENTH VIS MOOT - Flexoprint machine ….............................................. 118

N FOURTEENTH VIS MOOT - Distribution fuse boards ....................................119

O FIFTEENTH VIS MOOT - Blue Hills 2005 wine ................................................ 120 


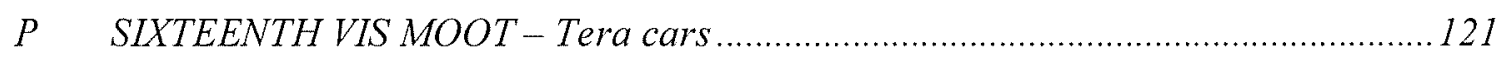

Q SEVENTEENTH VIS MOOT - Water Pumps ............................................... 123

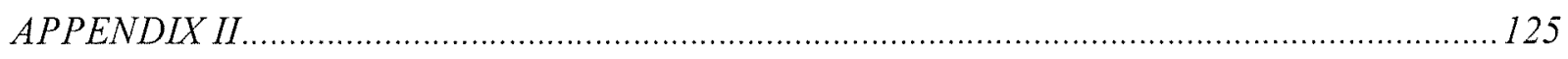

UNITED NATIONS CONVENTION ON THE INTERNATIONAL SALE OF GOODS 1980_....125 
Ever since the first Vis Moot in 1993 an international community of legal academics, practitioners, arbitrators and researchers has worked together to annually explore current trends and topics on the application of the CISG through the Vis Moot. In each of the seventeen problems different aspects of the application of the CISG were featured. This dissertation will seek to trace recurring themes and discuss issues and arguments that arose from the competition. The result will produce a guide on the evolution of CISG-related jurisprudence over the past seventeen years and demonstrate the impact of the annual moot on CISG-related legal developments.

\section{Relevance of the Vis Moot fact scenarios}

The Vis Moot is a forum where the international legal community dealing with the application and interpretation of the CISG can regularly test its ideas. The problems and the memoranda provide a good testing ground for arguments and insights on interpretation of the CISG. The Vis Moot is an opportunity for an exploration of the practical workability of the CISG in commercial scenarios both in terms of the text of the CISG, as well as the case law and commentary available on its application. The Vis Moot problems are filled with practical everyday issues relating to contractual relationships in the fast pace of the business reality. The Vis Moot is also a forum for further harmonisation of ideas, as it brings together different legal traditions and the common and civil law perspective. The Vis Moot problems provide a range of "hot topic" case studies which give a good overview of the application of the CISG over the past seventeen years. As an illustration, the eighth Vis Moot problem featured a jurisdictional issue which was concurrently being considered by UNCITRAL ${ }^{\text {. }}$.

\footnotetext{
'Eric E. Bergsten, "Teaching about International Commercial Law and Arbitration: the Eighth Annual Willem C. Vis International Commercial Arbitration Moot” (2001) $18 \mathrm{~J}$ Int Arbit No 4, 481-486, 484.
} 
Bergsten, ${ }^{2}$ one of the initiators of the Vis Moot and its administrator, stated that the Vis Moot was first proposed at "the UNCITRAL Congress on International Commercial Law in 1992, as a means of interesting law students in the work of UNCITRAL, more specifically in the [CISG] and in international commercial arbitration"3. The original purpose of the Vis Moot was to publicise the CISG. Nottage points out that the Vis Moot promotes CISG education and fosters CISG trained lawyers worldwide ${ }^{4}$ :

\begin{abstract}
A major development with few parallels in other areas where harmonisation of commercial law has been initiated, is the Vis Arbitral Moot Competition... The experience is so educational, in so many ways, that the large group of Vis Moot alumni is probably already growing into a major force for consistent yet creative engagement with CISG in cross-border commercial practice.
\end{abstract}

Since there is no international court which oversees the application of the CISG, and while a large number of international disputes involving the CISG are resolved by arbitrations whose proceedings and decisions remain confidential to the parties, the Vis Moot is the key event where the worldwide discussions on the application of the CISG can freely occur. The memoranda of the Vis Moot address particular questions of fact and law by reference to academic writing and commentary, case law and any available arbitration decisions. In some instances they interpret the existing position, while in others they may offer alternative views on the interpretation of the CISG. Therefore, while the Vis Moot problems provide interesting case studies, the memoranda provide good analysis of these case studies, summarising and considering vast amounts of available and up-to-date material on the CISG. The fact that this worldwide debate takes place regularly each year further enhances its usefulness in the sense that it tracks the developments in this area at a steady and constant pace.

\footnotetext{
${ }^{2}$ Professor Bergsten is a Professor Emeritus at Pace University Law School, has had a distinguished sixteen-year career with the United Nations where he served the United Nations Commission on International Trade Law (UNCITRAL), first as Senior Legal Officer and then as Secretary of the Commission. From 1985-1991 he was Chief of the International Trade Law Branch of the Office of Legal Affairs. Professor Bergsten developed and administers Pace's Willem C. Vis International Commercial Arbitration Moot held annually in Vienna, Austria. Professor Bergsten has been awarded a "Special Award" by the International Law and Practice Section of the New York State Bar Association, a "Special Commendation" for his achievements as Director of the Willem C. Vis International Commercial Arbitration Moot by the Section on Dispute Resolution of the American Bar Association, and the Silver Medal of Honor (Silberne Ehrenzeichen) by the City of Vienna, Austria.

${ }^{3}$ Eric E. Bergsten, above n 1, 481 .

${ }^{4}$ Luke Nottage, "Who's Afraid of the Vienna Sales Convention (CISG)? A New Zealander's view from Australia and Japan" [2005] VUWLRev 39, 128-129.
} 
Legal rules strive to anticipate and encompass a wide scope of general issues, embracing and regulating most common and predictable conduct. Human conduct will undoubtedly swerve in unanticipated directions, and events will combine in such a way to form grey areas which do not appear to fit neatly into the rules. Enter academics, practitioners, judges and students - all coming together to discuss those grey areas and consider their place within the overall legal framework. While the articles and the commentary generally take the CISG as their starting point and consider its application to the factual scenarios, the Vis Moot allows a reverse exploration how to fit and analyse factual scenarios in relation to the CISG. With many arbitration decisions unreported, with no international court as the pinnacle and centre of CISG jurisprudence, and with all the liberty of jurisprudential exploration an academic forum allows - the Vis Moot is the hub of CISG discussion, an open plain where factual scenarios filled with previously unexplored grey areas are explored from all angles by the worldwide CISG community. The result is a mirror of the evolution of CISG related jurisprudence over the past sixteen years.

This dissertation considers the various fact scenarios and issues raised in the sixteen Vis Moot questions. Both the fact scenarios and the issues gained in complexity as the competition progressed - from three to four page problems to fifty page problems. The scenarios are concerned with interpretation of contracts in relation to key CISG issues, for example conformity of goods with the contract, avoidance of the contract, notice periods and damages. Part I of this paper provides the background on the Vis Moot and its general relevance in the field of the CISG; Part II discusses the CISG, its background, purpose and general outline; Part III analyses the evolution of the Vis Moot problems against the backdrop of the jurisprudential developments on the CISG, and in particular provides an analysis of the key issues raised and developed over the past couple of decades; and Part IV sets out the conclusions reached based on the research carried out and the analysis provided in Part III. Appendix I to this dissertation sets out brief factual summaries of each Vis Moot for ease of reference; and Appendix II sets out the full text of the CISG. 
The movement to unify the law relating to the international sale of goods which started in the 1920s gave birth to the CISG. The CISG entered into force on 1 January 1988, and has been widely accepted; according to $\mathrm{UNCITRAL}^{5}$ seventy-four states have adopted the CISG. The Convention was adopted by a diplomatic conference on 11 April 1980. It is a comprehensive legal code which sets out rules, inter alia, and primarily regarding formation of contract, obligations of buyers and sellers and remedies for breach of contracts. The purpose of the CISG is set out in the preamble ${ }^{6}$ :

\begin{abstract}
... uniform rules which govern CISG and take into account the different social, economic and legal systems would contribute to the removal of legal barriers in international trade and promote the development of international trade.
\end{abstract}

The goal of commercial law is to promote predictability, certainty, balance and efficiency. These are viewed as being in line with the parties positions when entering every new transaction, namely without knowledge of potential outcomes should things go wrong. ${ }^{7}$ As discussed by Caruba: ${ }^{8}$

\begin{abstract}
Across the modern world, efficiency is the dominant theoretical paradigm of commercial law jurisprudence, and the goal of domestic contract law in market economies is to provide efficient rules that supplement the normative frameworks which support exchange transactions. Parties engaged in international commerce, however, face potentially significant additional transaction costs due to the nonuniformity of domestic laws. Moreover, the dynamic inconsistency problem arises when local courts are perceived as partisan and biased, creating another potentially significant barrier to global economic efficiency.
\end{abstract}

The proposed solution for this problem of global economic efficiency is the worldwide adoption of uniform commercial law governing transnational sales, together with recognition and

\footnotetext{
${ }^{5}$ http://www.uncitral.org/uncitral/en/uncitral_texts/sale_goods/1980CISG.html

${ }^{6}$ United Nations Convention on Contracts for International Sale of Goods (April 111980 ) 1489 UNTS 3 (CISG).

${ }^{7}$ Sandra L Caruba, "Globalisation as a nexus between the historical narratives of international law and commercial law" Issue 3 (NZPGLeJ) 26.

${ }^{8}$ lbid, 34.
} 
enforcement of judicial decisions from neutral dispute resolution bodies. These steps have been taken already to a large extent, through the application of the CISG and international arbitration mechanisms. Mistelis ${ }^{9}$ has commented that the CISG is "one of the most successful international instruments which produce uniform substantive rules for international trade"10. Mistelis also noted that two thirds of international sales transactions are conducted between parties based in CISG countries ${ }^{11}$ :

In addition more than 1,000 judicial and arbitral decisions have been identified and are now featured in the relevant databases, such as www.cisg.law.pace.edu. In this sense, CISG is a successful and mature text of protean nature, which has been supported and enhanced by legal practice over the last 15 years. Most recently, UNCITRAL, the CISG formulating agency, has completed a digest which provides a comprehensive presentation of case law on the CISG and aims at assisting courts in the application of the Convention.

The CISG is therefore a widely adopted, accessible and comprehensive document, offering business people and lawyers a logical and consistent framework within which to conduct efficient cross-border transactions. ${ }^{12}$ However, having uniform rules does not instantly ensure uniform application ${ }^{13}$, and the Vis Moot has been a particularly effective forum for, both the exploration of the extent to which the CISG is being applied uniformly across different jurisdictions, as well as in promoting uniform application. The question whether the uniform text is indeed effectively achieving its purpose through presence, or lack of its uniform application worldwide is crucial in the analysis of the overall success of the Convention. The Vis Moot sheds light on the degree to which such success has been achieved to date, and lights the way in

\footnotetext{
${ }^{9}$ Dr. Loukas A Mistelis, LLB, MLE, Dr.iuris, MCIArb, Advocate, is the Clive M Schmitthoff Senior Lecturer in Commercial Law at the Centre for Commercial Studies, Queen Mary, University of London. He acts as Secretary of the CISG Advisory Council.

${ }^{10}$ Loukas Mistelis, "CISG-AC Publishes First Opinion", available at: http://www.cisg.law.pace.edu/cisg/CISGAC.html (last accessed on 12 November 2009).

"Ibid.

${ }^{12}$ Luke Nottage, above n4, 69-70, discusses the aspects of accessibility and consistency of the CISG: "The CISG offers a logical, coherent and comprehensive framework for working through quite complex legal issues that can develop in negotiating and implementing cross-border sales. One key advantage is therefore the accessibility of the Convention... The layout of the CISG is also logical, generally tracking the issues as they arise in actual commercial transactions." And at 81: "If the dispute does come before a court, and especially if it comes before an arbitral tribunal, CISG offers much more chance of consistency in interpretation...Finally, these general advantages of accessibility, intelligibility and consistency extend beyond dispute resolution processes. CISG also can benefit business people and their legal advisers when they are negotiating and drafting sales (and, indeed, other commercial agreements). Familiarity with its rules can provide more meaningful and generalisable checklists and guidance on matters to be addressed and negotiated when planning cross-border deals."

${ }^{13}$ Franco Ferrari discusses this in his article "Uniform Application and Interest Rates under the 1980 Vienna Sales Convention" 24 GA J Int'1 \& Comp. Law, 467; as well as in his article "Homeward Trend and Lex Forism Despite Uniform Sales Law" (2009) 13 VJ 15-42.
} 
the direction where further work is required so as to further approach the goal of uniformity. This paper explores the degree to which uniform application has been achieved to date, as reflected in the Vis Moot problems, in the following chapters.

\section{B Text and Structure of the CISG-An Outline}

In order to better understand the operation and application of the CISG, it is worthwhile to briefly canvass its structure and provide an overview of its provisions. The full text of the Convention is enclosed in Appendix II of this paper. The CISG is comprised of four parts, namely application and general provisions (Part I), formation of contract provisions (Part II), substantive rules (obligations, rights and remedies of the parties - Part III), and final provisions (Part IV). Article 92(1) allows a state to implement the CISG without Parts II and III. The CISG has a "horizontal" structure, namely the rights and obligations of the parties are set out separately from the parties' remedies. The Vis Moot problems primarily address issues arising in the provisions of Parts II and III of the CISG, being those parts of the CISG dealing with the substantive issues in international contracts.

Part I contains the general provisions and those relating to the application of the CISG. The CISG applies to contracts for the sale of goods between parties whose places of business are in different states. ${ }^{14}$ The CISG does not apply to goods bought for personal, family or household use, auctions, sale by execution of law (e.g. bankruptcy), stocks, shares, investment securities, negotiable instruments, ships, vessels, hovercraft or aircraft and electricity ${ }^{15}$. The CISG applies to goods to be manufactured, unless the buyer supplies a substantial part of the materials, and does not apply to contracts in which "the preponderant part of the obligations of the seller consists in the supply of labour or other services". ${ }^{16}$ The CISG does not cover the validity of the contract or of any provisions or of any usage or the effect the contract may have on the property in the goods sold. ${ }^{17}$ Article 5 provides that the CISG does not apply to liability of the seller for death or personal injury caused by the goods sold. Articles 7 and 8 are of key importance when interpreting the CISG. Article 7 requires that regard must be had to the international character of

\footnotetext{
${ }^{14}$ Article 1(1)(a) CISG.

${ }^{15}$ Article 2 CISG.

${ }^{16}$ Article 3, CISG.

${ }^{17}$ Article 4, CISG.
} 
the CISG, the need to promote uniformity in its application and good faith in international trade and provides that where an issue is inadequately covered or cannot be solved applying the general principles the CISG is based on, the rules of international private law will apply. Article 8 provides a framework for interpreting the intention of the parties in relation to the other provisions of the CISG. Conduct by a party, as well as statements made by that party, are to be interpreted in accordance with either that party's intention or the reasonable person standard, taking into account established practices and usages between the parties. Article 8 has been vastly applied and commented on, and as will be seen from the discussion to follow, has been a key feature of most Vis Moot problems.

Part II sets out the provisions dealing with offer and acceptance. An offer under the CISG will be effective once it reaches the offeree. The offer must indicate what the relevant goods for sale are and make provision for determining their quantity and price. An offer cannot be revoked if it indicates it is irrevocable, an offeree relied on it, and it was reasonable for that offeree to rely on it being irrevocable. Acceptance becomes effective once it reaches the offeror, vis-à-vis the postal rule. The period of time for acceptance begins on the date of the letter or at the time the instantaneous communications reaches the offeree.

Part III contains all the substantive provisions relating to the regulation of the sale of goods under the CISG. It is divided into five chapters, namely general provisions (I), obligations of the seller (II), obligations of the buyer (III), passing of the risk (IV) and provisions common to the obligations of the seller and the buyer (V). The first chapter deals with communication between the parties, amendments of the contract, form of avoidance of contract and requirement for ordering specific performance. The key provision in this chapter is article 25 which defines "fundamental breach" for the purposes of the CISG. A party may avoid the contract on the basis of the other party having committed a fundamental breach under articles 49 or 64 . Whether a breach is fundamental is a question of fact, and this provision has merited numerous discussions in Vis Moot problems. The second chapter sets out all obligations relating to the seller of the goods, including: delivering the goods on time, handing over the relevant documents, providing a warranty that goods are free from third party claims and that the goods are in conformity with the contract. Article 35 covers the requirements for conformity with the contract, namely that the goods are of the quality, quantity and description under the contract, or that they are fit for either 
the "purposes for which goods of the same description would ordinarily be used"18 or fit for a particular purpose "expressly or impliedly made known to the seller". ${ }^{9}$ Other requirements for conformity include possessing the qualities as held out by a sample and adequate packaging of the goods. ${ }^{20}$ Where the buyer knew or could not have been unaware of a lack of conformity at the time of the conclusion of the contract, the seller will not be held liable. ${ }^{21}$ Conformity of the goods issues have featured heavily in the Vis Moot case studies. The third chapter sets out the buyer's obligations, which include paying the price and taking delivery of the goods as required by the contract and subject to other provisions of the CISG. The seller may declare the contract avoided where the buyer fundamentally breaches the contract under article 25 , or where the buyer does not perform, or declares it will not perform, its obligations, and declaration is made within a reasonable time and before the performance is rendered. Parts IV - VI contain provisions dealing with the passing of the risk ${ }^{22}$, provisions applicable to both parties (including anticipatory breach, damages, interest, exemptions, effects of avoidance, and the requirements to preserve the goods for the other party) and final provisions ${ }^{23}$ respectively.

As seen above, the CISG presents a very clear and accessible structure. Part VI is not the subject of the present analysis as it does not concern substantive provisions. Part $I$ is relevant in that it contains certain key provisions on interpretation. In particular Article 7 is of major relevance as the overriding clause on uniformity and uniform application of the CISG embodying the doctrine which lies at the heart of all CISG jurisprudence and analysis as well as the Vis Moot. Article 8 is another key interpretation provision which affords a detailed analysis in the present work. Parts II- V will also be considered in the context of those key trends and issues which have emerged over the past seventeen years.

\footnotetext{
${ }^{18}$ Article 35(2)(a), CISG.

${ }^{19}$ Article 35(2)(b), CISG.

${ }^{20}$ Article $35(2)(\mathrm{c})$ and (d), CISG.

${ }^{21}$ Article 35(3), CISG.

${ }^{22}$ In general, the risk passes when the goods are provided to the first carrier, and where the seller is required to deliver the goods to a specific place, the risk will pass once the goods reach that place.

${ }^{23}$ Part VI contains the final provisions, allowing the contracting states to opt out of Part II and Part III or article 1(1)(b). Apart from these three options, no other reservations are permitted. The CISG does not prevail over other international agreements to which the contracting states are a party to.
} 


\section{A General Discussion}

\section{$1 \quad$ Evolution of the Vis Moot Problems}

The Vis Moot problems have evolved considerably since the inception of the inaugural competition held in Vienna in 1993. The problems have changed mainly in terms of the following broad categories: the manner and form in which the problem is presented, the complexity of issues involved and the increase in focussed and narrowed discussion. Each of these is explored in tum below.

\section{(a) Presentation of Problems}

The first two years of the Vis Moot saw the problem presented as a narrative of facts, confined to the length of four (in the inaugural year) and eight (in the second year) pages. This formulation of the problem is familiar to any common law student that has participated in local mooting competitions. The narrative supplies the student with all the relevant (and some irrelevant) facts, and it is entirely up to the student to elucidate the issues, the applicable law and the grounds to be pleaded. This format quickly evolved in the third and fourth Vis Moot to present the problem as a series of documents, as would be the case in an actual arbitration, including the notice of arbitration and statement of claim, claimant's exhibits such as all relevant documentation and correspondence between the parties, statement of defense and applicable notices and orders from the arbitral tribunal. This form still retained the narrative of the facts in its statements of claim and defense, but provided further details on the formulation of issues, grounds pleaded and relief sought. In the following years the emphasis on the arbitration issues was also substantially increased, to ensure the problems allowed an equal share of CISG and procedural arbitration issues to be raised and discussed. As such, the problems continually increased in size to reach some forty-eight pages in the sixteenth year. The practical approach 
adopted, namely the presentation of the problem in a manner closest resembling an actual arbitration, has also been perfected over the years, and the problems now contain detailed sets of documents for participants to analyse, including clarifications and procedural orders from the tribunal issued subsequent to the problem being released and a period of time for participants to send queries on the facts to the drafters.

\section{(b) Complexity of Issues}

The evolution of the form in which the problems are presented, as discussed above, has enabled an increase in highly sophisticated formulation of factual scenarios, issues to be disputed, and consequently participants' memoranda. The problems present a web of complex facts which ideally contain ambiguities akin to those found in real life arbitrations and recent cases, yet carefully geared to balance the arguments on both sides, thus providing fertile ground for an in depth exploration of the issues.

\section{(c) Focussing the discussion}

The growth in complexity of the facts and the problems has also been accompanied by a tendency to increasingly pin-point the issues in the problem thus narrowing the scope of discussion and focussing it on a particular aspect of the dispute. This trend is in contrast to the earlier problems which were formulated quite broadly and thus allowed for more exploration of potential issues at the outset. The narrowing down of the issues and focussing of the discussion on particular aspects of the dispute has the tendency to approach the discussion as an in-depth analysis of current problems in CISG jurisprudence (as well as arbitration, although that is not the subject of analysis here), rather than open up the possibilities for a broader exploration of its application. 
The amount of academic writing, opinions and reported decisions has increased considerably in the past seventeen years. The increased focus on specific issues within CISG topics in Vienna is a mirror image of the parallel increase in CISG jurisprudence, allowing the move from a broader discussion to a more sophisticated exploration of complex issues and fact scenarios. The memoranda reflect this increase in development, availability and richness of materials on the CISG through their discussions of relevant academic writing and decisions and reliance on such sources in their arguments. It is particularly evident through certain problems that the jurisprudence in particular areas has evolved considerably. For example, Articles 8, 35 and 79 have all been subject of vigorous debate and voluminous opinions both in academic commentaries and reported decisions, and have consequently been a feature of various Vis Moot problems throughout the years.

\section{$3 \quad$ Key trends}

Over the years the Vis Moot problems have involved issues over a range of industries. ${ }^{24}$ The problems have thoroughly surveyed CISG jurisprudence on almost all possible aspects of the Convention's application. Considered in toto, the problems comprise a comprehensive casebook on the application of most aspects of the CISG. Some problems addressed very specific issues, for example infringement of third party IP (application of Article 42, which arose only once in the eight year); while others explored general principles in the application of interrelated areas of the Convention, such as the eleventh Vis Moot which involved consideration of issues of non-conformity of goods, fundamental breach and avoidance. A survey of the seventeen problems sheds light on very clear trends which have emerged over the years. Article 8 has featured in arguments each year ${ }^{25}$, such consistent reference and application of it providing a wealth of information on its application. Conformity of goods issues (Article 35) have been

\footnotetext{
${ }^{24}$ Industries used in mooting problems included computer chips, telecommunications equipment, central heating and air conditioning, clothing, speculative oil drilling and exploration, paper production, commodities such as grain and cocoa, sporting equipment, textiles, investment banking, packaging equipment, electrical equipment, wine, and cars. ${ }^{25}$ Although, according to the winning memoranda, the sixth and the sixteenth problems don't appear to raise an Article 8 argument. The winning memoranda of the sixteenth problem only contains a passing reference to Article 8 . Although memoranda from the first four years of the competition are no longer available, there is little doubt that Article 8 did not form a part of arguments in those problems.
} 
among the most common problems raised throughout the years. Other common themes include problems concerning provisions dealing with formation of contract questions (Articles 14-24), fundamental breach (Article 25), avoidance of contract (Article 49), force majeure as embodied in Article 79 and problems concerning awards of damages (chiefly Articles 74 and 77). Interestingly, the CISG Advisory Council has released nine opinions on various aspects of the interpretation of the CISG which rather starkly parallel the common themes recurring throughout the seventeen years of the Vis Moot. The first opinion examined the issue of electronic communications under the $\mathrm{CISG}^{26}$ (such questions touching on formation of contract concerns); the second considered the application of Articles 38 and $39^{27}$ (being the reasonable time for examination of goods delivered and reasonable time for providing the notice of non-conformity, both relevant in the application of the non-conformity provision, ie Article 35); the third considered, inter alia, the questions of application of the parol evidence rule and plain meaning rule to the $\mathrm{CISG}^{28}$ (arising in the context of the interpretation provisions, primarily Article 8 ); the fifth discussed the issues of avoidance in cases of non-conforming goods ${ }^{29}$ (in particular touching on problems of fundamental breach issues as required by Article 25); the $\operatorname{sixth}^{30}$ and eight $^{31}$ opinions considered problems relating to calculation of damages; the seventh ${ }^{32}$ opinion

\footnotetext{
${ }^{26}$ CISG-AC Opinion No.1 "Electronic Communications under CISG", 15 August 2003. Rapporteur: Professor Christina Ramberg, Gothenburg, Sweden, available at: http://www.cisgac.com/default.php?ipkCat $=128 \&$ ifkCat $=143 \&$ sid $=143$

${ }^{27}$ CISG-AC Opinion No.2 "Examination of the Goods and Notice of Non-Conformity: Articles 38 and 39,7 June 2004". Rapporteur: Professor Eric E. Bergsten, Emeritus, Pace University School of Law, New York., available at: http://www.cisgac.com/default.php?ipkCat=128\&ifkCat=144\&sid=144

${ }^{28}$ CISG-AC Opinion No.3 "Parol Evidence Rule, Plain Meaning Rule, Contractual Merger Clause and the CISG, 23 October 2004. Rapporteur: Professor Richard Hyland, Rutgers Law School, Camden, NJ, USA, available at: http://www.cisgac.com/default.php?ipkCat $=128 \&$ ifkCat $=145 \&$ sid $=145$

${ }_{29}$ CISG-AC Opinion No. 5 "The buyer's right to avoid the contract in case of non-conforming goods or documents", 7 May 2005, Badenweiler (Germany). Rapporteur: Professor Dr. Ingeborg Schwenzer, LL.M., Professor of Private Law, University of Basel, available at: http:/www.cisgac.com/default.php?ipkCat=128\&ifkCat=147\&sid=147

${ }^{30}$ CISG-AC Opinion No. 6 "Calculation of Damages under CISG Article 74",

Rapporteur: Professor John Y. Gotanda, Villanova University School of Law, Villanova, Pennsylvania, USA, available at: http://www.cisgac.com/default.php?ipkCat $=128 \&$ ifkCat $=148 \&$ sid $=148$

${ }^{31}$ CISG-AC Opinion No. 8 "Calculation of Damages under CISG Articles 75 and 76", Rapporteur: Professor John Y. Gotanda, Villanova University School of Law, Villanova, Pennsylvania, USA. Adopted by the CISG-AC following its 12 th meeting in Tokyo, Japan, on 15 November 2008, available at:

http://www.cisgac.com/default.php?ipkCat $=128 \&$ ifkCat $=148 \&$ sid $=184$

${ }^{32}$ CISG-AC Opinion No. 7 "Exemption of Liability for Damages under Article 79 of the CISG", Rapporteur: Professor Alejandro M. Garro, Columbia University School of Law, New York, N.Y., USA, available at: http://www.cisg.law.pace.edu/cisg/CISG-AC-op7.html
} 
considered the force majeure exemption set out in Article 79; and the ninth ${ }^{33}$ revisited the consequences of avoidance of the contract under either of Articles 49 or $64^{34}$.

A quick consideration of these trends leads to questioning of the reasons behind the emergence of these central themes. Is this emergence due to ambiguities in the drafting and application of those provisions? Do these themes recur since they constitute the key issues that will arise from contractual disputes, no matter what the applicable law? Are they reintroduced for educational reasons, to ensure that participants gain a good understanding of such key issues and operation of the Convention? Answering any of these questions in the positive is not in any way to the exclusion of the others. The overall answer lies somewhere along the continuum of all of these propositions. As will be demonstrated below, over the past seventeen years the Vis Moot has combined, with great success, its educational aspects (in providing the participants with an excellent understanding of the CISG through its complex problems and combination of CISG issues), and its jurisprudential aspects - by revisiting key problems which arise from international sales contracts, by considering potential gap-areas in the application of the CISG in its fact scenarios, and by providing a testing ground for new ideas in an attempt to address such gap areas. These key trends will be analysed in Part B of this dissertation, and will illustrate both the educational and jurisprudential outcomes of this global annual event.

\footnotetext{
${ }^{33}$ CISG-AC Opinion No. 9 "Consequences of Avoidance of the Contract", Rapporteur: Professor Michael Bridge, London School of Economics, London, United Kingdom. Adopted by the CISG-AC following its 12 th meeting in Tokyo, Japan on 15 November 2008, available at: http://www. cisgac.com/default.php?ipkCat $=128 \&$ ifkCat $=148 \&$ sid $=185$

${ }^{34}$ The full list of the CISG Advisory Council opinions, and the opinions themselves, are available at: http://www. cisgac.com/default.php?sid $=128$
} 


\section{B Analysis of Key Trends and Issues}

(a) Introduction

Article 8 is a key provision of the CISG. It encapsulates the principle that the parties' intention takes priority over the freedom of contract concept embedded in Article 6 as well as the other provisions of the $\mathrm{CISG}^{35}$. It also sets out the rules on interpretation of the parties' intentions. Interpreting the interpretation provision has occupied scholars and practitioners alike since the adoption of the CISG. The first ${ }^{36}$ and second ${ }^{37}$ English editions of the Schlechtriem Commentary provide a good demonstration of the significant developments in the jurisprudence on Article 8 over the years. For example, the first English edition contains a four and a half page discussion of Article 8, while the second English edition provides some thirty pages. Beyond this superficial level exists the substantive difference between the two editions, the second far broader in scope and content than the first. Similarly, Honnold's early discussion (in his 1999 commentary) of Article $8^{38}$ is reasonably brief, while the UNCITRAL cites 42 cases in its 2008 case law digest on Article $8^{39}$, with the full list of reported cases on the Pace Law database revealing approximately 300 decisions ${ }^{40}$.

Article 8 is significant for both agreements that have not resulted from detailed negotiations, as well as detailed agreements that may have been modified by informal communications ${ }^{41}$. Article 8 concerns interpretation of "statements made" and "other conduct",

\footnotetext{
${ }^{35}$ Junge in Schlechtriem, Peter (ed) Commentary on the UN Convention on the International Sale of Goods (CISG) (2nd ed (in translation)) (Clarendon Press, Oxford, 1998), 69.

${ }^{36}$ Schlechtriem, Peter (ed) Commentary on the UN Convention on the International Sale of Goods (CISG) ( $2 \mathrm{nd}$ ed (in translation)) (Clarendon Press, Oxford, 1998).

${ }^{37}$ Schlechtriem, Peter and Schwenzer, Ingeborg (eds) Commentary on the UN Convention on the International Sale of Goods (CISG) (2nd (English) ed) (Oxford University Press, Oxford/New York, 2005).

${ }^{38}$ Honnold, Uniform Law of International Sales, 3 ed, 1999, 115- 123.

${ }^{39}$ UNCITRAL Digest of case law on the United Nations Convention on the International Sale of Goods, Digest of Article 8 case law, available at: http://www.cisg.law.pace.edu/cisg/text/digest-art-08.html

${ }^{40}$ The decisions are listed and available at: http://www.cisg.law.pace.edu/cisg/text/digest-cases-08.html (last updated on November 4, 2009).

${ }^{41}$ Honnold, above n39, 115.
} 
including legally relevant conduct, of the parties to the sales contract under the $\mathrm{CISG}^{42}$. Article 8 , therefore, has a very broad reach across the Convention, encompassing statements made both as part of contract formation, as well as the operative, post contract formation, sale of goods provisions. In particular it is applied for interpreting communications such as, inter alia, the making of an offer (Articles 14), revocation (Article 16), communication of acceptance (Article 18), rejection of offer through counter-offer (Article 19), notification of avoidance (Article 26), modification or termination of agreement (Article 29), notifications as to the non conformity of goods (Article 39) and interruption or failure to perform (Article 48, 68, 71, 72, 79 and 88) ${ }^{43}$.

A brief overview of the winning Vis Moot memoranda over the years of the competition ${ }^{44}$ demonstrates that Article 8 has been raised in arguments in each problem ${ }^{45}$. Although the memoranda for the first four years of the Vis Moot are no longer available, there is little doubt that Article 8 featured in the arguments. It is not surprising to see Article 8 applied so consistently and across the board given its umbrella effect over the other provisions of the CISG.

In the second English edition of the Schlechtriem Commentary, Schmidt-Kessel observed that paragraphs 1 and 2 of Article 8 are often not distinguished from each other ${ }^{46}$, and that this inability to distinguish them derives from a "double application" of Article 8(3), namely the need to apply Article 8(3) criteria "in determining the actual intent of the party making the statement and in determining the hypothetical understanding of the other party" ${ }^{47}$. The examples of application of Article 8 discussed below illustrate this point with great clarity.

(b) Subjective approach - Intent - Article 8(1)

Article $8(1)$ is an aid to interpretation of CISG contracts through the subjective test, namely, where the one party knew or could not have been unaware of the other party's subjective

\footnotetext{
${ }^{42}$ Schmidt-Kessel in Schechtriem, above n38, 112: "Article 8 governs the interpretation of statements made by and other conduct of the parties of a sales contract subject to the CISG as well as the interpretation of all legally relevant conduct of the parties to the contract."

${ }^{43}$ Honnold, above n39, 115 .

${ }^{44}$ The memoranda for the years 1-4 are not available, therefore only the memoranda from years $5-16$ have been reviewed.

${ }^{45}$ The exceptions are the sixth and the sixteenth problems which don't appear to raise an Article 8 argument. The winning memoranda of the sixteenth problem only contain a passing reference to Article 8 .

${ }^{46}$ Schmidt-Kessel in Schechtriem and Schwenzer, above n38, Article 8, para 20, 120.

${ }^{47}$ Schmidt-Kessel in Schechtriem and Schwenzer, above n38, Article 8, para 20, 120.
} 
intention, that subjective intention takes priority ${ }^{48}$. For example, in the twelfth Vis Moot an argument was made for the Claimant that based on various telephone discussions, the actual terms of the contract and subsequent communications between the parties, the buyer's intention that the goods be delivered within a specific timeframe was clearly articulated to the seller and that the seller was aware of that intention ${ }^{49}$. Another key question in this problem was whether the goods contracted for had to be of a particular origin, namely whether the contract required that the cocoa ordered had to be from the country of Equatoriana. Both sides relied on Article $8(1)$ in interpreting their intentions. The actual written contract concluded between the parties, as well as the initial letter confirming the order did not explicitly refer to the origin of the cocoa beans. Claimant put forward the argument that, according to its conduct following the conclusion of the contract, it was evident that the cocoa beans did not have to be from Equatoriana. It based this on its communications to Respondent where it stated that "contract did not provide specifically for Equatoriana cocoa" and "our contract was for cocoa, not for Equatoriana cocoa", 50 . Thus, arguably, Claimant's intention was clear in that it understood that any cocoa in the relevant category of quality, no matter what its origin, was the subject matter of the parties' contract. Claimant further argued that lack of any objection from Respondent to such statements supports the argument that Respondent was aware of this intention and was of the same understanding ${ }^{51}$. Respondent contained its counter-argument to the objective test under Article 8 (2) which will be explored below. Whether the above facts truly demonstrate Claimant's intentions is in fact a matter of debate. Claimant only expressed the above views once it was aware that the delivery of cocoa from Equatoriana may be delayed, and the change in circumstances concerning the price of the particular grade of goods contracted for. Therefore, the intention in isolation of all circumstances, namely application of Article 8(3) and a consideration of the objective test under $8(2)$ is insufficient to conclude whether the goods contracted for had to be of a specific origin. Honnold also commented that "because of practical barriers to proving identity between the intent of the two parties (particularly when they are involved in a controversy) most problems of interpretation will be governed by paragraph 2 which follows the

\footnotetext{
${ }^{48}$ See Junge in the Schlechtriem, above $n 37,70$.

${ }^{49}$ See University of Copenhagen Memorandum for Claimant, Twelfth Vis Moot, para 8.

${ }^{50}$ Ibid., paragraph $82,19$.

sl Ibid.
} 
"objective" approach" 52 . This is clearly illustrated by an argument presented in the fifth Vis Moot where Claimant submitted that Article 8(1) was inapplicable since Respondent's intent "regarding revocability was neither clear nor ascertainable" and that consequently it had to turn to the reasonable person test in paragraph $2^{53}$. Article $8(1)$ is therefore unlikely to feature as the key argument, but rather a supplementary consideration reinforcing the objective approach arguments under paragraph 2 and the consideration of "all relevant circumstances" under paragraph 3.

(c) Objective approach - reasonable person in the same type of business - Article 8(2)

Article 8(2) contains the objective test for interpretation of the parties' intentions, namely the test of the understanding of a "reasonable person" of the same kind as the other party and in the same circumstances. It is important to take into account the limitations of this objective test. The test is limited by the following requirements: the need to take into account "all relevant circumstances" pursuant to Article 8(3); the considerations of "a reasonable business person in the same type of business" 54 ; and due weight to be given to the wording of the relevant statements made by the parties ${ }^{55}$. This test is therefore more constrained than may be initially perceived.

In the example of the twelfth Vis Moot considered above, Respondent based its argument on the requirement for the cocoa beans to be of Equatiranean origin on the test in paragraph 2. It argued that, objectively, several elements indicate that the beans contracted for had to be from Equatoriana. The first of these elements was the price, which was for the lowest quality of cocoa beans available on the market ${ }^{56}$, and only produced in a small number of countries. The price contracted for, it was argued, strongly limited the countries from which the

\footnotetext{
${ }^{52}$ Honnold, above n39, 118.

${ }^{53}$ Ruprecht-Karls-University, Heidelberg, Memorandum for Claimant, Fitth Vis Moot, para A,A, 1, 2.

${ }^{54}$ Schmidt-Kessel in Schlechtriem and Schwenzer, above n38, 121; also see Schiedsgericht der Börse für landwirtschaftliche Produkte in Vienna, 10 December 1997.

${ }^{55}$ Schmidt-Kessel in Schlechtriem and Schwenzer, above n38, 120. Schmidt-Kessel observes: "Along with the circumstances named in Article $8(3)$ is also the implication for paragraph 2 that the applicable paradigm is that of a professional in the relevant branch".

${ }^{56}$ See Humboldt-Universität zu Berlin, Memorandum for Respondent, Twelfth Vis Moot, para 1, 5.
} 
beans could have been procured ${ }^{57}$. Moreover, it argued that, since Claimant expressly required "low grade and inexpensive cocoa", and since it produces a substantial amount of cocoa annually, it understood, and could not have been unaware, of the correlation between quality and price and the link between quality and origin ${ }^{58}$. It further argued that the name of the company, namely "Equatoriana Commodity Exporters" indicated that the cocoa beans were sourced in Equatoriana, and that had this not been the case the name would more likely be "Equatoriana Commodity Traders" ${ }^{39}$. Finally it was argued, that given Claimant contracted to bear all costs of transportation from the delivery point, it could not have intended to contract for cocoa beans from any potential country of origin. It concluded that Claimant's statements as to the irrelevance of the country of origin were made at the time when the price had risen unexpectedly and rather significantly, and that such proclamations were motivated by the knowledge of those special circumstances. This example demonstrates the battle of interpretation of intent that may be carried out through application of paragraphs 1 and 2 of Article 8 by either party, and the incompleteness of application of either one or the other in isolation. Any application of paragraphs 1 and 2 of Article 8 should be subject to the test in Article 8(3) which provides an umbrella for the first two paragraphs - namely, any attempt at elucidating parties' intent must be carried out with regard to "all relevant circumstances". This is a deliberate choice of words and not limited to "some circumstances" or as wide as "all circumstances", but requiring a certain determination of what constitutes relevant circumstances within the contested factual scenario.

Article 8 may not always be applied in a meticulously organised way; nonetheless arguments may achieve the interrelated application of paragraphs 1,2 and 3 on a conceptual level as discussed above whether or not they are construed in a strictly technical manner. For example, in the fifth Vis Moot both parties relied on Article 8 in interpreting Claimant's statement and ascertaining whether it constituted a rejection pursuant to Article 17 or a counteroffer pursuant to Article 19. The parties framed their interpretation chiefly in reference to Article $8(2)$ by considering how Claimant's statement would be interpreted by a reasonable person in the same position as Respondent. This analysis was conducted by both sides by investigation of all

\footnotetext{
${ }^{57}$ Ibid.

${ }^{58} \mathrm{Ibid}$.

${ }^{59}$ Ibid. This argument was further supported by references to other companies with similar names which were only concerned with exporting goods from the country of origin which was contained in their name.
} 
relevant circumstances, hence application of paragraph 3, to elucidate Claimant's intention (paragraph 1). Respondent presented the argument that Claimant's statement in its reply to Respondent's offer that "...[t]he price of $\$ 30,000,000$ is the same price that we rejected in our meeting with you on 9 May 1997. It is just too much..." presented a clear intention of Claimant to reject Respondent's offer. Due to the contentious nature of the subjective intention, it had to be established through the test in paragraph 2 of how a reasonable person in Respondent's position would have understood this statement having in mind all the relevant circumstances (paragraph 3). Thus, Respondent argued that given Claimant has on previous occasion, and during informal negotiations, rejected the same offer in respect of the price, any reasonable seller would construe its written statement as a restatement of that rejection ${ }^{60}$. Following the similar pattern of analysis in reference to paragraph 2, Claimant argued that a reasonable person in Respondent's position would have arrived at the conclusion that Claimant did not intend its statement as a rejection of the offer, based on the context and duration of the parties' negotiations, Claimant's commercial interests related to the contract and the marginal value of the price difference in issue ${ }^{61}$. This application presents a well framed application of the Article $8(2)$ test in reference to paragraphs 1 and 3.

(d) All relevant circumstances - Article 8(3)

According to Article 8(3) all relevant circumstances, including any pre-contractual negotiations ${ }^{62}$ as well as subsequent conduct after the conclusion of the contract ${ }^{63}$, must be taken into consideration when interpreting the parties' intensions.

The tenth Vis Moot demonstrates the holistic application of Article 8, by presenting arguments based both on paragraphs 1 and 2 within the overall guise of paragraph 3 . In the tenth Vis Moot, an issue arose, inter alia, as to whether the contract between the parties (had it been concluded, as its conclusion was also contested) included a discount amounting to $4 \%$ or $8 \%$ of

\footnotetext{
${ }^{60}$ University of Münster, Memorandum for Respondent, Fifth Vis Moot, Issue 1, AI1.

${ }^{61}$ University of Münster, Memorandum for Claimant, Fifth Vis Moot, Issue 1, AI1.

${ }^{62}$ Bundesgerichtshof, 3 April 1996 [VIII ZR 51/95] (Cobalt sulphate case), Germany; Oberster Gerichtshof $2 \mathrm{Ob}$ 163/97b, 1999, Austria; MCC-Marble Ceramic Center v. Ceramica Nuova Dágostino 144 F.3d 1384 (11th Cir. 1998), United States; Filanto S.p.A. v. Chilewich Int'l Corp. 91 Civ. 3253 (CLB) 1992, United States.

${ }^{63}$ See also Bezirgericht St. Gallen, 3 July 1997, (Fabrics case), Switzerland.
} 
the purchase price. Both sides submitted their respective arguments as to which of the discount percentages ought to apply with reference to an Article 8 analysis. The parties have concluded an agreement on a previous occasion which included an $8 \%$ discount. Claimant set out its argument chiefly in reference to Article $8(1)$, by submitting that Respondent could not have been unaware of its intent to grant a $4 \%$ discount in the disputed contract, which was the second contract (arguably), concluded between the parties ${ }^{64}$. It supported this proposition by an Article 8 (3) analysis of "all relevant circumstances", which consisted of the following: the $8 \%$ discount granted in the initial contract was an "incentive one time offer applying to that contract only" 65 which was evident since that initial contract "points out that the discount of $8 \%$ is the highest discount ever given by Claimant to any customer for any purchase" aware of this, it could not have been unaware of the one off nature of this discount. Claimant then imported the paragraph 2 test of a reasonable person in the same type of business by arguing that "as a sales manager of a large international company, [Respondent's representative] could not have been unaware that special discounts are given in the polypropylene market for special reasons such as first time orders" ${ }^{\prime 67}$. Moreover, a promise by Claimant that Respondent will always receive its "best price" did not amount to an explicit guarantee of an $8 \%$ discount in all future dealings. Claimant then reverted to the paragraph 1 test by concluding that, based on all relevant circumstances, Claimant could not have been aware of Respondent's intent to conclude a contract including an $8 \%$ discount, while Respondent could not have been unaware that the contract included a $4 \%$ discount ${ }^{68}$. The final sentence of this argument, however, concludes that the contract included the $4 \%$ discount based on the paragraph 2 test - namely based on the understanding of a reasonable person in the same circumstances as Respondent.

The eleventh Vis Moot also presents an excellent example of Article 8(3) analysis. The key issue in the eleventh Vis Moot was whether the machines purchased by Claimant from Respondent were in conformity with the contract concluded between the parties (in accordance with Article 35). The requirements of a contract pursuant to Article 35 can be derived both

\footnotetext{
${ }^{64}$ Rheinische Friedrich-Wilhelms-Universität Bonn, Memorandum for Claimant, Tenth Vis Moot, para 65, 24.

${ }^{65}$ Ibid.

${ }^{66} \mathrm{Ibid}$.

${ }^{67}$ Ibid, para 69, 24.

${ }^{68} \mathrm{Ibid}$, para 73, 24.
} 
expressly and impliedly ${ }^{69}$. This problem demonstrated the kind of ambiguities that may arise when attempting to elucidate implied requirements of a contract. Claimant purchased packaging machines from Respondent which, as it stated in its communication to Respondent, it required in order to package "a wide range of dry bulk commodities...both fine... and coarser goods"70. Claimant used some of the machines to package salt, and consequently, the machines corroded and were rendered useless. A dispute arose between the parties and Claimant argued the contract required the machines to be able to package corrosive goods such as salt, and Respondent that it was not aware of any such requirement. Both parties relied on Article 8 to elucidate whether the ability to package salt, or other corrosive goods, was implied in the requirements that were contracted for. Claimant submitted a combination of paragraph 1 and 3 arguments. It relied on both pre-contractual negotiations and subsequent conduct. In terms of Article 8(1), Claimant referred to the clarity of its intentions as must have been evident to Respondent, in view of all relevant circumstances (ie applying the paragraph 3 test). The relevant circumstances included pre-contractual negotiations and subsequent communications from which it was communicated to Respondent that Claimant anticipated entering into a contract with a large retail food store, and that Respondent was aware that the machines would be required to package foodstuffs in satisfaction of that contract ${ }^{71}$. Claimant argued that its broadly framed pre-contractual inquiry implied that machines must be capable of packaging all dry bulk commodities without limitations $^{72}$, and moreover, that Respondent was the party with the special skill and knowledge ${ }^{73}$ as to the different capabilities of different models. As such, Claimant relied on Respondent's skill and knowledge to advise it adequately in respect of its goods ${ }^{74}$. Respondent held itself out to be a "premier manufacturer for the food packaging industry and its recommendation of a particular model was therefore understood in the context of its specialist knowledge. Claimant's enumeration of potential items it needed to package, in Claimant's view,

\footnotetext{
${ }^{69}$ Schlechtriem and Schwenzer, above n38, 413; Fritz Enderlein and Dietrich Maskow International Sales Law: United Nations Convention on Contracts for the International Sale of Goods, Convention on the Limitation Period in the International Sale of Goods (Oceana, New York, 1992), Art 35, para 1.

${ }^{70}$ Eleventh Vis Moot Problem, Claimant Exhibit 1.

${ }^{71}$ University of Heidelberg, Memorandum for Claimant, Eleventh Vis Moot, para 51, 15-16.

${ }^{72}$ Ibid.

${ }^{73}$ Bundesgerichtshof 31 October 2001 [VIII ZR 60/01] (Machinery case), Germany; Roland Schmidt GmbH v. Textil-Werke Blumenegg AG Bundesgericht 22 December 2000, Switzerland; Junge in Schlechtriem, above n37, 71.

${ }^{74}$ University of Heidelberg, Memorandum for Claimant, above $\mathrm{n} 72$, para 52, 16, in reliance on Cesare Massimo Bianca and Michael Joachim Bonell (eds) Commentary on the International Sales Law: The 1980 Vienna Sales Convention (Giuffré, Milan 1987), Art. 35 para. 2-3; Enderlein and Maskow, above n70, Art. 35 para. 13.
} 
should have been sufficient to give Respondent enough information to "perceive the purpose of its goods out of the circumstances" 75 and that "specific requirements can be deduced from the purpose and the circumstances of the contract, even if there is no agreement" ${ }^{76}$. Claimant therefore concluded that the contract required the machines delivered to be capable of packaging a wide range of dry bulk commodities, including salt. This analysis of the contract, taking into consideration Claimant's intention considered in light of paragraph 1 and all relevant circumstance under paragraph 3 , presents a very persuasive argument for Claimant. Turning very briefly to Respondent's argument it is evident that Article 8 affords Respondent's interpretation of the contractual requirements equally persuasive. Respondent submitted that Article 8(1) only presents the test that it "knew or could not have been unaware". As such, since salt was not explicitly mentioned by Claimant, and since it is a corrosive good, in a different category from the ones explicitly mentioned by Claimant, Respondent would have had to inquire further as to intended uses in order to find out if corrosive goods would be packaged. No such duty to inquire, however, exists within the Article 8 requirements ${ }^{77}$. Parties also disputed whether a telephone conversation between them some time after the contract was concluded, during which Claimant allegedly mentioned salt in passing as one of the goods to be packaged, was to be interpreted as creating a new contractual requirement. It constitutes "subsequent conduct", and arguably, where explicit mention of a particular purpose is subsequently made, Respondent could not have been unaware of it. This problem demonstrates the intricacies of applying Article 8 tests to complex factual scenarios, and the effect of its interpretation rules on construction of contracts, in particular determination of implied terms. It demonstrates the scope of application of Article 8 and its overall importance in construction of contracts according to principles specific to the CISG.

\footnotetext{
${ }_{75}^{75} \mathrm{Ibid}$, in reliance on Schlechtriem and Schwenzer, above $\mathrm{n} 38,421$.

${ }^{76}$ Landgericht München [5HK O 3936/00], 27 February 2002 (Globes case), Germany; ICC Court of Arbitration, Award No. 8213, March 1995 (Steel billets case).

${ }^{77}$ National University of Singapore, Memorandum for Respondent, Eleventh Vis Moot, 9. The premise that no duty to inquire exists under Article 8(1) is supported by Enderlein and Maskow, above n70, 170; Honnold, above n39, 350 .
} 
(e) Article 8(3) and the Parol Evidence Rule

The parol evidence rule, long established in common law, bars consideration of any agreement prior or contemporary with the written agreement concluded between the parties ${ }^{78}$. The rule has been interpreted in a way which precludes any extrinsic evidence of terms agreed, yet excluded from the final written contract concluded between the parties, could not be given, and the parties would be limited to the written word of the contract whether or not it was incomplete or inaccurate ${ }^{79}$. However, this rule has been expressly excluded from the CISG, in fact Article 8 may be seen as being quite explicit in overriding any such rule. Honnold welcomed this aspect of the Convention ${ }^{80}$ :

But Article $8(3)$ relieves tribunals from domestic rules that might bar them from
"considering" any evidence between the parties that is relevant. This added
flexibility for interpretation is consistent with a growing body of opinion that the
"parol evidence rule" has been an embarrassment for the administration of modern
transactions.

The application of the test of Article 8(3), namely "due consideration is to be given to all relevant circumstances of the case" has been embraced as an interpretive aid to the CISG. Illustrating the opposite effect of the use of this test are the arguments presented by the parties in the fifteenth Vis Moot. One of the issues considered in this problem was whether the wine sold by Claimant to Respondent was in conformity with the contract concluded between the parties. The contract was concluded via a purchase order signed by the representatives of both Claimant and Respondent. The purchase order only contained the basic information as to the transaction, namely the names of the parties, the quantity of the goods ordered, the name of the goods ordered, the price per unit, the total price payable, and the delivery details, including dates and quantities for delivery of various instalments and relevant conditions. No details were included in the purchase order as to the quality of the wine, or as to its ingredients. Respondent argued that the wine purchased was not in conformity with the contract due to it having diethylene glycol in

\footnotetext{
${ }^{78}$ Honnold, above n39, 121. The rule is formulated in Bank of Australasia v Palmer [1987] AC 540, at 545 by Lord Morris as: "Parol testimony cannot be received to contradict, vary, add to or subtract from the terms of a written contract, or the terms in which the parties have deliberately agreed to record any part of their contract."

${ }^{79}$ Petra Butler "The Doctrines of Parol Evidence Rule and Consideration - A Deterence to the common Law Lawyer?" presented in "Celebrating Success: 25 Years United Nations Convention on Contracts for the International Sale of Goods" (Collation of Papers at UNCITRAL - SIAC Conference 22-23 September 2005, Singapore), Singapore International Arbitration Centre, 54-66, 59.

${ }^{80}$ Honnold, above n39, 121.
} 
its content. In support of this argument, Respondent relied on Article 8(3) as confirming that "the pre-contractual declarations of the parties may be used to determine the intent of a party or the understanding of the parties" $"$. Respondent then proceeded to rely on various statements made by both parties in relation to the wine, namely Claimant's statement that it was an "outstanding choice for a promotion of quality wines" featuring it in its promotion as the leading product, that Claimant reaffirmed its previous statement by claiming that Respondent was "making a wise choice in choosing Blue Hills 2005 as the lead wine in your promotion" $" 83$ and "that this is an exceptionally fine wine that will certainly satisfy all your customers" ${ }^{84}$. Thus, Respondent argued that the pre-contractual communications exchanged between the parties can be relied on to demonstrate that the parties agreed upon "a high quality standard of wine in the purported contract itself" argued importing the pre-contractual discussions into the terms of the written contract, namely the purchase order.

\section{Legal analysis}

The above examples demonstrate the difficulty in distinguishing which limb of Article 8 to apply. The examples show that one side will refer only to paragraphs (1) and/or (2) of Article 8 in its arguments in an attempt to limit the argument to either the subjective test, or to the "reasonable person in the same type of business" ${ }^{\text {" }}$ test. The side wishing to keep its argument as broad as possible and take into account a wider variety of facts will rely on Article $8(3)$ as the overriding umbrella for any consideration of Articles (1) and (2), which is the appropriate application $^{87}$. In relying on either test of Article 8, paragraph 3 must be taken into account. As such, the reliance on paragraphs 1,2 , and 3 interchangeably, or even relying on one paragraph while actually satisfying a more holistic test, appears to be the norm. This overlapping

\footnotetext{
${ }^{81}$ University of Heidelberg, Memorandum for Respondent, Fifteenth Vis Moot, para 93.

${ }^{82}$ Fifteenth Vis Moot, Claimant Exhibit no.1.

${ }^{83}$ Ibid, Claimant Exhibit no.3.

${ }^{84}$ Ibid, Claimant Exhibit no.3.

${ }^{85}$ University of Heidelberg, Memorandum for Respondent, above n82, para 94.

${ }^{86}$ Schmidt-Kessel discusses this test at length: Schmidt-Kessel in Schlechtriem and Schwenzer, above n38, Article 8, para $24,121$.

${ }^{87}$ Julius von Staudinger Kommentar zum BGB mit Einführungsgesetz und Nebengesetzen - Wiener UN-Kaufrecht (CISG), Sellier-de Gruyter, Berlin 2005, Art 8, para 17.
} 
application of the three limbs and the resulting confusion in their individual application is consistent with the academic views expressed on this point ${ }^{88}$.

Given the all-encompassing reach of Article 8, it is no surprise to find it emerging in arguments in Vienna each year. Its consistent and constant use demonstrates that it is of key importance in the application of the CISG. The ongoing application of its various tests throughout the years of the competition demonstrates that up-coming practitioners are ready to use it in arguments in its own right, free from their domestic doctrines on contract interpretation. This freedom from domestic doctrines is at the essence of Article $8^{89}$ :

\footnotetext{
The purpose of this provision is to reject formal restrictions on the material to be interpreted by the court. The Convention does not contain any formal obstacle regarding interpretation and overrides any conflicting domestic rules.
}

Application of Article 8 requires a real shift in thinking for both civil and commercial lawyers since it introduces a very distinct contract interpretation framework. The Vis Moot memoranda display a sustained effort to move away from domestic doctrines and apply Article 8 tests in their own right. In this respect they are a valuable source on current issues arising out of its application, as well as on the way this provision is currently being applied in interpreting CISG contracts.

(a) Introduction

Part II of the CISG contains the rules on contract formation (Articles 14 to 24). These are broadly divided into two categories, namely rules as to formality (including writing requirements, certainty of terms and admissibility of evidence) and offer-acceptance rules (including offer, acceptance and revocation rules). One distinct difference between the contract formation rules contained in the CISG and the common law jurisdictions is the lack of the parol

\footnotetext{
${ }^{88}$ Schmidt-Kessel in Schlechtriem and Schwenzer, above n38, 120: analysis of Article 8(2) must include consideration of all relevant circumstances under Article 8(3).

${ }^{89}$ Schmidt-Kessel in Schlechtriem and Schwenzer, above n38, 117.
} 
evidence rule and consideration doctrines in the $\mathrm{CISG}^{90}$. As considered in the context of Article 8 above, pre-contractual negotiations, subsequent conduct, namely "all relevant" circumstances should be taken into account when constructing contracts and "filling gaps". Likewise, the common law doctrine of consideration has no place within the CISG, as stated in the Secretariat Commentary on Article $29^{91}$, and as clearly demonstrated by that very rule which provides that "a contract may be modified or terminated by the mere agreement of the parties" 92 .

Issues of contract formation have arisen in various Vis Moot problems, although without any visible pattern. For example, the fifth and the tenth Vis Moot problems concerned the existence of a valid offer and acceptance, while the fifteenth addressed issues of revocation. The scattered and reasonably scarce problems on contract formation issues, in comparison with other key provisions of the CISG, parallels the reasonably scarcity of a tremendous body of commentary and decisions which has emerged in relation to some of the other provisions, such as Articles 8,35 and 79 for example. These parallels, and the key issues related to these rules, are further explored in the following paragraphs.

(b) Sufficiently Definite Offer \& Agreement on Price - Article 14

Article 14 regulates the conditions under which a proposal to enter into a contract constitutes an offer ${ }^{93}$. The article sets out the basic principles that the party making the "offer" must have the intention of being bound and that the "offer" must be sufficiently definite ${ }^{94}$. A relevant question was identified by UNCITRAL, namely whether price has to be agreed for the contract to be concluded under CISG. In particular, whether the price has to be "expressly or implicitly" included in the contract and whether a there must be provision made for

\footnotetext{
${ }^{90}$ Petra Butler, above $\mathrm{n} 80$; Butler explores whether the absence of the parol evidence rule and consideration doctrines from the CISG is an obstacle to the uptake of the CISG in the common law jurisdictions. The article concludes that the absence of these doctrines is not, or at least should not be deterrence to a common law lawyer.

${ }^{91}$ Secretariat Commentary on Article 29, paras 2- 3; available at: http://www.cisg.law.pace.edu/cisg/text/secomm/secomm-29.html

${ }_{92}$ Petra Butler, above n80; Butler discusses this issue in some detail.

${ }^{93}$ UNCITRAL Digest of case law on the United Nations Convention on the International Sale of Goods, Digest of Article 14 case law, paragraph 1, available at: http://www.cisg.law.pace.edu/cisg/text/digest-art-14.html

${ }^{94}$ UNCITRAL Digest of case law on the United Nations Convention on the International Sale of Goods, Digest of Article 14 case law, paragraph 1, available at: http:/www.cisg.law.pace.edu/cisg/text/digest-art-14.html
} 
determination of the price ${ }^{95}$. A question of price in relation to contract conclusion was explored in the tenth Vis Moot.

The tenth Vis Moot concerned a dispute as to whether a contract was concluded between the parties. Respondent argued that no contract of sale was concluded between the parties as no real intention, in the interpretation envisaged by applying Article 8(1), existed between the parties to agree on the purchase price (since Respondent expected an $8 \%$ discount, and Claimant offered a $4 \%$ discount). Respondent submitted that the "agreement over the purchase price is essential for the conclusion of a contract of sale" and further that it is an "essentialium negotii" Respondent therefore concluded that the fact that agreement was reached on other terms, such as type of goods and quantity for example, and that both parties treated their exchange of faxes as a concluded contract is irrelevant as the essential term, the price, was not agreed ${ }^{97}$. Claimant, on the other hand, had a more of an uphill battle in presenting it views. It argued that the parties did conclude a contract for sale through their exchange of faxes which confirmed their oral agreement during a previous telephone conversation, and as such confirmed both parties intent to be bound ${ }^{98}$. Moreover, Claimant submitted that the agreement did exist on the price, since Claimant confirmed that Respondent will receive "its best price" which will include a discount", despite no express reference to the amount of such discount having been confirmed. It was argued in the alternative that, with or without an agreement being reached on the discount, the contract was concluded. This is based on several premises, the gist of which is that the agreement did not arise out of an exchange of declarations, but out of a document which is signed by both parties ${ }^{100}$ and that the agreement on the discount was not necessary in order to conclude a valid contract ${ }^{101}$. The argument is further developed by arguing that, because the proposal needs to be sufficiently definite to constitute an offer under Article 14, and that an offer is sufficiently definite if it determines the price, it cannot be that the contrary will apply - namely that not fixing or making provision for determination of the price is not sufficiently definite and

\footnotetext{
${ }^{95}$ Honnold, above n39, 150.

${ }^{96}$ University of Cologne, Memorandum for Respondent, Tenth Vis Moot, para 50, 18.

${ }^{97}$ Ibid, para 52, 19.

${ }^{98}$ Rheinische Friedrich-Wilhelms-Universität Bonn, Memorandum for Claimant, Tenth Vis Moot, para 53, 19.

${ }^{99}$ Ibid, para 54, 20.

${ }^{100}$ Ibid, para 56, 21.

${ }^{101}$ Ibid, para 57,21 .
} 
thus not binding ${ }^{102}$. A body of opinion is cited to support the proposition that the conclusion of the contract cannot be hindered by a missing provision for the determination of price, as this would run contrary to the general principles of the CISG, and that a contract with the intention by both parties to be bound must be respected ${ }^{103}$. It further finds authority for the proposition that the "necessity for contracts without a predetermined price must not be ignored", since such contracts "facilitate international commercial relationships", and a requirement for a predetermined price would render them useless ${ }^{104}$. Finally Claimant concluded that Article 55 should be used should it be determined that the price as not agreed.

This example illustrates the difficulties which may arise in applying the Article 14 test when an ambiguity as to price exists. While the general opinion is that, for an offer to be sufficiently definite under the second sentence of Article 14(1) it must both indicate the goods and expressly or implicitly fix or make provision for determination of the price. Nonetheless, in one decision it was held that, if the intent to be bound by an acceptance is established, a proposal is sufficiently definite notwithstanding the failure to specify the price ${ }^{105}$. Moreover, other decisions have confirmed this view in broad terms by holding that the Convention may fill the gaps where certain terms of the proposed contract are missing in the offer, such as place of delivery or mode of transportation ${ }^{106}$. Therefore, determining whether the offer is sufficiently definite will be a matter of weighing out all the relevant circumstances and establishing the degree to which the above tests are satisfied. For example, in the case of the tenth Vis Moot the intricacy of applying these test lay somewhere along the middle of the threshold test. The price itself was explicitly included; however the discount applying to it was not. A promise to get the seller's "best price" appears to lean further towards the insufficiently definite end of the scale, although the fact that the list price was explicitly provided for in the contract, and that the only missing aspect was the amount of the discount would pull the consideration in the opposite direction, namely toward the sufficiently definite end of the scale ${ }^{107}$. An ancillary question is

\footnotetext{
${ }^{102}$ Ibid, para 59, 22 .

${ }^{103} \mathrm{Ibid}$; this proposition is supported by Honnold, above $\mathrm{n} 39,155$.

104 Ibid.

${ }^{105}$ Handelsgericht des Kantons St. Gallen 5 December 1995 (Computer hardware devices case), Switzerland.

${ }^{106}$ Landgericht München 8 February 1995 (Standard software case), Germany; Amtsgericht Duisburg 13 April 2000 (Pizza cartons case), Germany.

${ }^{107}$ UNCITRAL Case Law Digest on Article 14 provides a helpful overview of the decisions which have held both views. The following scenarios were held to be sufficiently definite: pelts of varying quality to be sold "at a price
} 
whether the test in Article 55 would apply in these circumstances. Article 55 applies where the "contract has been validly concluded but does not expressly or implicitly fix or make provision for determining the price" ${ }^{\$ 108}$. The existence of this article in itself would favour the view that the contract can be validly concluded under Articles 14 and 18 , whether or not the offer included a price. Article 55 is intended as gap filler in these situations, and provides a formula for calculating it as being "the price generally charged at the time of the conclusion of the contract for such goods sold under comparable circumstances in the trade concerned"109. However, a survey of the decisions on the application of this Article reveals that it is only seldom that it is applied. Potentially the reason behind this difficulty with its application is precisely the dilemma which arises from this type of problematic - absence of a fixed price may tend towards the view that the contract was not validly concluded since the offer was not sufficiently definite, hence Article 55 will not apply; or, presence of a price, whether implicit or incomplete, may push in the direction of the understanding that Article 55 cannot apply due to some aspect of the agreement on price existing, in which case application of Article 55 test would be contrary to the parties' intentions and agreement ${ }^{110}$. Thus, the tenth Vis Moot provides an excellent example of the difficulties the issue of the setting of the price in the offer, and its relation to Article 55 poses. Honnold observed that the Article 14/55 interplay was conceived as a compromise during the drafting process to address the differences between those that were opposed to and those that supported open-price contracts ${ }^{111}$. As the above example and opinion illustrates, much like any compromise, its effectiveness is questionable.

\footnotetext{
between 35 and 65 German Marks for furs of medium and superior quality" because the price could be calculated by multiplying the quantity of each type by the relevant price; no specific agreement on price where a course of dealing between the parties established the price; a proposal that prices were to be adjusted to reflect market prices; agreement on a provisional price to be followed by establishment of a definitive price after the buyer resold the goods to its customer, because such an arrangement was regularly observed in the trade. The following scenarios were held to be insufficiently definite: a proposal that provided for several alternative configurations of goods but did not indicate a proposed price for some elements of the alternative proposals; an agreement that the parties would agree on the price of additional goods ten days before the new year. The full text with links to the relevant decisions is available at: http://www.cisg.law.pace.edu/cisg/text/digest-art-14.html

${ }^{108}$ Article 55 CISG, the full text of the CISG is set out in Appendix II.

${ }^{109}$ Article 55 CISG.

${ }^{110}$ UNCITRAL Digest of case law on the United Nations Convention on the International Sale of Goods, Digest of Article 14 case law, paragraphs 15 and 16, available at: http://www.cisg.law.pace.edu/cisg/text/digest-art-14.html

${ }^{11}$ Honnold, above $39,154$.
} 
(c) Acceptance, Rejection and Counter-Offer - Articles 18 and 19

Article 18 regulates the validity of the acceptance of the offer. The acceptance has to carry the offeree's intention of being bound by the offer ${ }^{112}$. According to Schlechtriem, and contrary to Honnold's view, "a contract is formed under Article 18(3) by conduct amounting to acceptance even where it is not communicated to the offeror" $" 13$. Therefore, this view holds that no notice of acceptance is required to be given by the party accepting the offer for the contract to be concluded. The contract is perfected once the acceptance reaches the offeror, or when assent is indicated in exceptional circumstances where this is permitted in accordance with Article $18(3)^{114}$. A rejection made by the offeree terminates the offer upon reaching the offeror, in accordance with Article 17. However, as noted by Honnold ${ }^{115}$ :

An offeree can create difficult problems by a response that is not a clearcut acceptance or rejection; the ambiguity may be a bargaining tool in the attempt to secure better terms while trying to hold the offer open.

Where this kind of ambiguity is present it will no longer be dealt with under Article 17, but under Article 19: "Acceptance" with Modifications. This Article deals with interpretation of a reply to an offer which "purports to be an acceptance but contains additions, limitations or other modifications" "16. Acceptance with modifications is an issue that came up for debate in the fifth Vis Moot. The fifth Vis Moot considered whether the contract was concluded between the parties, or whether the offer was rejected by a counter-offer within the meaning of Article 19. It involved an interesting set of facts surrounding a sale of a drilling rig ${ }^{117}$. Respondent made an offer to Claimant to sell a drilling rig ("rig \#23"), and the validity of the offer under Article 14 was not disputed. Claimant's reply to the offer was in dispute, with Respondent arguing it constituted a rejection and a counter-offer as envisaged by Article 19, and Claimant arguing it was "merely an informal inquiry as to the state of negotiations and hence of no legal significance" $" 118$. Prior to considering what these arguments are based it is important to set out

\footnotetext{
${ }^{112}$ Schlechtriem and Schwenzer, above $\mathrm{n} 38,219$.

${ }^{113}$ Schlechtriem and Schwenzer, above n38, 231.

${ }^{114}$ Schlechtriem and Schwenzer, above $\mathrm{n} 38,224$.

${ }^{115}$ Honnold, above, $\mathrm{n} 39,170$.

${ }^{116}$ Article 19(1) CISG.

${ }^{117}$ See Appendix I for fact summaries of Vis Moot problems.

${ }^{118}$ University of Münster, Memorandum for Claimant, Fifth Vis Moot, Issue 1, para AI(1).
} 
the relevant correspondence which formed the basis of the dispute ${ }^{119}$. Respondent sent a letter to Claimant offering to sell its rig\#23 at a price of $\$ 30,000,000$. Claimant then wrote to Respondent in reply where it stated "The price of $E \$ 30,000,000$ is the same price that we rejected in our meeting with you on 9 May 1997. It is just too much. A fairer price for the rig would be the $E \$ 28,000,000$ that we have already offered you, and we would ask you again to consider it."120 Shortly after this correspondence, a large oil field was discovered and the price of rigs shot up considerably (about 15\% and continued to rise). Claimant confirmed that in light of Respondent's rejection the rig\#23 was no longer offered for sale under the terms initially proposed, however Respondent swiftly confirmed that it did accept the offer previously made. The essence of the issue therefore lies in considering whether Claimant's initial response to the offer was a rejection and counter-offer in terms of Article 19. It may be the case that these facts afforded Claimant with a somewhat of a difficult battle to wage, given in particular its words "we would ask you again to consider [the price]". UNCITRAL lists price, payment, quality and quantity of the goods, place and time of delivery and statement of disputes as key terms whose modification is material ${ }^{121}$. Price is generally viewed as one of the terms, if subject to a modification renders it material ${ }^{122}$, subject only to the general exception of usages established by the parties or where both parties do not consider it a material modification ${ }^{123}$. Naturally, therefore, Respondent argued that the price was of material importance to the conclusion of the contract, and that without agreement as to price the contract could not have been concluded ${ }^{124}$. Claimant ran several arguments, primarily that no legal significance was attached to its reply as the reply did not conform to formal requirements of rejection and acceptance but was rather an informal inquiry ${ }^{125}$. It also argued that its letter did not constitute a rejection by a counter-offer since, in order to be seen a rejection by a counter-offer under Article 19 it had to purport to be an acceptance. Claimant therefore submitted that the words used, namely that Respondent's letter

\footnotetext{
${ }^{119}$ See Appendix I for the fact summary.

${ }^{120}$ Fifth Vis Moot Problem, Claimant Exhibit 3.

${ }^{121}$ See UNCITRAL Case Law Digest on Article 19, available at: http://www.cisg.law.pace.edu/cisg/text/digest-art19.html

${ }_{122}$ Oberster Gerichtshof, 10 Ob 344/99g, 21 March 2000 (Wood case), Austria; Magellan International v. Salzgitter Handel GmbH, No. 99 C 5153 United States District Court for the Northern District of Illinois, Eastern Division December 7, 1999, United States; Handelsgericht des Kantons Zürich 10 July 1996 (Plastic chips case), Swtizerland. See UNCITRAL Case Law Digest on Article 19, available at: http://www.cisg.law.pace.edu/cisg/text/digest-art19.html

$\frac{193}{123}$ Oberster Gerichtshof 20 March 1997 (Mono ammonium phosphate case), Austria.

${ }^{124}$ University of Münster, Memorandum for Respondent, Fifth Vis Moot, Issue 1, paragraph AIl.

${ }^{125} \mathrm{Ibid}$, paragraph AIl (a).
} 
comprising its offer was "a major disappointment" and that the price was "just too much" could not be construed as being a purported acceptance ${ }^{126}$. It's conclusion, with some logic, followed that given its response could not be construed as a rejection in terms of Article 17, nor could it be seen as a purported acceptance for the purposes of Article 19, it was of no legal significance. This conclusion demonstrates a very interesting point in the interoperability of the contract formation mechanisms in the CISG. On the one hand, keeping in mind the general principles of the CISG and applying its formation provisions conceptually, the above conclusion cannot be seen as the intended outcome of their application to that fact scenario. However, lawyers and judges deal with legal tests which are set out within defined parameters. As such, the above analysis is sound. Although the prevalent and conclusive opinion on the matter appears to be that the party's response to an offer has to be viewed as either a purported acceptance which includes modifications (under Article 19) or an implicit rejection (for example in the above case if the Claimant's response is interpreted as a demand for an offer on different terms) ${ }^{127}$. The interoperability of these provisions and their application may not always be as clear-cut as may appear at first glance, although their interpretation appears reasonably consistent and established in the main academic commentaries ${ }^{128}$. Interestingly, the UNCITRAL Case Law Digest concludes that there are no reported cases interpreting Article 17, and the Schlechtriem Commentary is relatively brief in its discussion. Whether this is a sign of a provision whose interpretation does not raise any interpretative questions, or a sign of a potential area for further consideration is not as evident.

\section{(d) Revocation - Article 16}

Whether an offer is binding and whether it may be revoked is the question to which answers vary greatly among different legal systems ${ }^{129}$ and as such was identified as one of the

\footnotetext{
${ }^{126}$ Ibid, paragraph AIl(b).

${ }^{127}$ Schlechtriem and Schwenzer, above n38, 215; for the discussion on implicit rejection by demand for an offer on different terms.

${ }^{128}$ See UNCITRAL Case Law Digest on Articles 17 and 19, available at: http://www.cisg.law.pace.edu/cisg/text/digest-art-17.html and http://www.cisg.law.pace.edu/cisg/text/digest-art$19 . \mathrm{html}$ respectively.

$\frac{199}{129}$ Schlechtriem and Schwenzer, above n38, 207; discusses these differences: "While the notion that an offeror is bound by his offer is established in Germanic legal systems and also in Scandinavia, the Romanic and common law
} 
most difficult issues dealt with during the drafting of the CISG ${ }^{130}$. Article 16 presents the compromised outcome of the attempt to accommodate various different views ${ }^{131}$. It rests on the general principle that an offer is revocable. However, this is restricted in a number of ways; primarily under Article 16(1) the revocation will be ruled out through the dispatch of acceptance or upon the conclusion of the contract ${ }^{132}$. The further restrictions are set out in Article 16(2)(a) and (b). Article 16(2)(a) provides that where the offeror sets a fixed time for acceptance he will be understood as having the intention of being bound by the offer during that time period. The offer will therefore not longer be revocable until the fixed time period has expired. Article $16(2)(b)$ provides that where the offerree has "acted in reliance on the offer" and where it was "reasonable for the offeree to rely on the offer being irrevocable" then the offer cannot be revoked.

The second English edition of the Schlechtriem Commentary does not expand greatly from the first, and a survey of CISG literature and decisions, and in particular the extremely brief UNCITRAL case law digest, ${ }^{133}$ reveals that the Article 16 issues have not been the most controversial, or the most debated, over the past couple of decades. This is also illustrated by the presence, or lack of, of this issue in the Vis Moot problems. Article 16 only featured as a key issue in the fifteenth year of the competition, and was one of the formation issues in the fifth. The CISG Advisory Council opinion on electronic communications under the CISG ${ }^{134}$ considered the impact on electronic communications on Article 16(1), in particular it was concluded that "the term "reaches" corresponds to the point in time when an electronic communication has entered the offeree's sever" while "dispatch" refers to the time when "the acceptance has left the offeree's server" 135 . This is qualified with the requirement that the relevant party has consented to receiving electronic communications "of that type, in that format,

legal systems have taken the opposite approach; moreover, differences exist as regards the possibility for an offeror to bind himself for a specific period and as regards the obligation to pay damages where an offer is revoked."

${ }^{130}$ See in particular Schlechtriem and Schwenzer, above n38, 207; and Honnold, above n39, 162.

${ }^{131}$ Schlechtriem and Schwenzer, above n38, 208.

${ }^{132}$ Schlechtriem and Schwenzer, above n38, 208.

${ }^{133}$ UNCITRAL Digest of case law on the United Nations Convention on the International Sale of Goods, Digest on Article 16, available at: http://www.cisg.law.pace.edu/cisg/text/digest-cases-16.html. There are only 3 cases mentioned in the UNCITRAL Digest and 11 listed on the Pace Law website above. (last updated June 30, 2009).

${ }^{134}$ CISG-AC Opinion No.1 "Electronic Communications under CISG", 15 August 2003. Rapporteur: Professor

Christina Ramberg, Gothenburg, Sweden available at: http:/ www.cisgac.com/default.php?ipkCat $=128 \&$ ifkCat $=143 \&$ sid $=143$

${ }^{135}$ Ibid. 
and to that address"136. These very issues were explored in the fifteenth Vis Moot where it was alleged that the e-mail revoking the offer only "reached" the offeree a day after the acceptance was dispatched due to a server failure, and that, either way e-mail was not appropriate for the communication of the revocation in the circumstances. The developmental trend of the competition is evident from the leap between the arguments presented in these to Moots. The arguments presented in the fifth Vis Moot were far more concise, while the Memoranda from the fifteenth present a very thorough, comprehensive analysis of the application of all various limbs of Article 16, they survey and consider a vast amount of scholarly writing and provide a range of alternative arguments and propositions ${ }^{137}$. These two problems and the manner in which they were tackled by the participants present a good insight in the practical application of Article 16, whose value is even greater given the scarce amount of reported decisions in this area.

In the fifth Vis Moot Respondent allegedly revoked its offer subsequent to Claimant's purported rejection or counter-offer (that rejection or counter-offer also being in dispute, please see the previous chapter). Claimant argued that the offer was irrevocable and applied the relevant tests in Article 16 in support of this position. It started with Article 16(2)(a) by arguing that Respondent fixed a time period for acceptance when it made the statement "...we expect to hear from you by June 10" which in itself is sufficient to render the offer irrevocable and binding within that time. Claimant referred to the legislative history of Article 16(2)(a) to support this view: "during the CISG draft negotiations, the United Kingdom proposed an amendment, which provided that the mere existence of a fixed time period for acceptance was insufficient to render the offer irrevocable. This proposal was explicitly rejected by the conference" ${ }^{\prime 38}$. Claimant further went on to construe Article 16(2)(a) "in the context of the CISG as a whole" 139 which is an approach to interpretation consistent with Article 7(1) and the overall spirit of the Convention. Claimant further argued that the fixed time period does not mean the offer will lapse once the it has expired, but that the fixing of the time period renders the offer binding for its duration ${ }^{140}$. Claimant also briefly argued Article 16(2)(b), namely that it relied on the offer and that such reliance was reasonable, demonstrated by the fact that Claimant did not enter into negotiations

\footnotetext{
136 Ibid.

${ }^{137}$ See for example University of California Berkley School of Law, Memorandum for Claimant, Fifteenth Vis Moot.

${ }_{138}$ Ruprecht-Karls-University, Heidelberg, Memorandum for Claimant, Fifth Vis Moot, para A, A, 1, 2.

139 Ibid.

${ }^{140}$ Ibid.
} 
with third parties and was making arrangements in respect of the eventual purchase of rig\#23 $3^{141}$. Respondent presented an interesting argument in terms of Article 16(2)(b), by stating that "it is universally recognised that Art. 16(2)(b) CISG requires acts such as: onerous price calculations, preparatory obtaining measures, extensive investigative acts or simply financial measures in general" ${ }^{\prime 142}$. Without undertaking any such measures, the other side's inactivity only amounts to a delayed acceptance, and as such cannot be seen to satisfy requirements of paragraph 2 (b) ${ }^{143}$.

The fifteenth Vis Moot is another excellent case study and guide on the practicalities of applying Article 16. Respondent and Claimant negotiated a contract for purchase by Respondent of 20,000 cases of a particular wine. Respondent sent Claimant a purchase order for Claimant to sign and return. Respondent declared the offer revoked by e-mail one day prior to Claimant dispatching its acceptance. Claimant allegedly only received the e-mail after it dispatched its acceptance due to a server failure. Both the revocation and the acceptance occurred a couple of days prior to the expiry of the fixed time period for acceptance, the fixing of the time period also being in dispute. These facts were ripe with Article 16 issues, calling for arguments by both parties by applying all of the Article 16 tests. Was the offer revoked prior the dispatch of the acceptance thus preventing the conclusion of the contract (Article 16(1))? Did Respondent state a fixed time for the acceptance of its offer, thus making it irrevocable prior to the expiry of that time (Article 16(2)(a))? Did Claimant reasonably rely on the offer being irrevocable within that timeframe (Article 16(2)(b))? Both sides presented particularly detailed and comprehensive arguments on all of these points. The winning memorandum for Claimant was particularly sophisticated, with its arguments spanning from reliance on the "plain meaning of Article 16(2)(b), an analysis of the parties' conduct with a view to Article 8, a restatement of scholarly opinion, to practical policy considerations. It also argued Claimants reliance and the reasonableness of such reliance, that the e-mail was an inappropriate form of communication for revoking the offer and that the e-mail did not reach Claimant prior to the dispatch of acceptance ${ }^{144}$. One interesting angle taken by these submissions was the reliance on certain domestic doctrines in an attempt to interpret the application of Article 16. For example, in

\footnotetext{
141 Ibid.

${ }^{142}$ University of Münster, Memorandum for Respondent, Fifth Vis Moot, Issue 1, para AI2(b).

${ }^{143}$ Ibid.

${ }^{144}$ University of California, Berkley School of Law, Memorandum for Claimant, above n137, 14-23.
} 
relation to the validity of the communication of revocation Claimant relied on common law authorities on the premise that "the English common law authority on this issue is especially appropriate given the common law origin of the revocability rule in Article 16(1), ${ }^{, 145}$. Further, Claimant noted the lack of reported decisions on Article 16(2)(a) and the nature of the clause being the compromise between different legal doctrines. It reached the same conclusion as Claimant in the fifth Vis Moot, namely that the fixed time period does not mean the offer will lapse once the it has expired (which is the general common law approach), but that the fixing of the time period renders the offer binding for its duration (being the general approach in the civil law countries). While Respondent would prefer to follow the common law approach, Claimant argued that "the provision should be interpreted "in the spirit of civil law whose rule it embodies" $" 146$.

These examples illustrate that Article 16 issues tend to arise where commercial circumstances change unexpectedly prior to the conclusion of the contract between the parties, for example the discovery of the new oil field suddenly driving the prices of drilling rigs up in the fifth Vis Moot, or sudden press coverage of the alleged quality issues with the wine purchased for promotion and resale in the fifteenth. Where such intervening factors change the negotiating landscape prior to the conclusion of the contract one party is generally in the position in which it may benefit, commercially and materially, from pulling out of the transaction and concluding it anew; while the other party is likely to suffer some form of loss as a result of such revocation. The consequence of these conditions is that, where the seller is (as in the above examples) the party who stands to benefit from the contract being concluded on new terms, he will seek to revoke his offer, while the buyer who stands to lose if the contract is not concluded will do his best to show that the offer is irrevocable and that the contract was concluded. One interesting commonality emerging from the above two examples is the manner in which the parties' have sought to interpret tests in Article 16 given the lack of reported decisions and the volume of scholarly writing existing in respect of other parts of the Convention. Schlechtriem commented on the issue of compromise and lack of reported decisions in 2004:

... and the form of Article 16 eventually adopted, also reflect the attempt to accommodate different views. However, ultimately, the price of compromise was a

\footnotetext{
${ }^{145}$ Ibid, para $113,22$.

${ }^{146}$ Ibid, para $84,22$.
} 
lack of clarity. Experience gained in connection with Article 5 ULF, on which there are no published decisions regarding revocability, and the lack of (published) decisions on Article 16 up-to-date (spring 2004), gives grounds for hoping that farreaching differences between the legal systems on fundamental points and the copious learned debate on the subject do not reflect practical needs. Article 16(2)(b) should, instead, be used as a source of principles for gap-filling under Article $7(2)$, in order to show, where necessary, that the prohibition of contradictory conduct is such a principle.

However, given the parties will resort to relying on a battle between the application of a common law understanding versus the civil law understanding in an attempt to support their view of the manner in which Article 16 should be interpreted, it may be that further guidance on its application would only benefit the wider CISG community and aid in the uniform application of these rules in the spirit of the Convention.

\section{(e) Legal analysis}

Part II issues do not appear to have caused as much of a stir as some other aspects of the Convention, with only a comparatively limited amount of opinion and a very small number of reported decisions to guide practitioners in the application of the formation of contract rules. Although not the most controversial area, several issues continue to exist in respect of contract formation, and they have been raised and discussed in several Vis Moot problems, one such issue being the interaction between and application of Articles 14 and 55. The common theme that appears to emerge from the analysis of Part II is the manner in which compromised solutions were designed to meet vastly diverging legal doctrines. The provisions seek to strike a balance between these diverging doctrines and introduce a comprehensive set of rules on contract formation which satisfy the unique context of contracts for the international sale of goods and the spirit of the CISG and strive towards a unified approach. The relatively scarce amount of scholarly analysis paired with the small amount of reported decisions may be either a sign of a successful outcome of this approach, or perhaps a demonstration of the need for further analysis and guidance on the uniform application of these provisions which will limit their interpretation in reference to domestic rules. 
(a) Introduction

At the heart of many sale of goods disputes is the question whether the goods delivered conform to the contract. Article 35 is at the very core of the CISG and presents a unified approach on the obligations of the seller in respect of the goods delivered to the buyer ${ }^{147}$. It is not surprising that this provision has been the subject of extensive analysis over the years, both through scholarly commentary and reported decisions. Paralleling this trend, Article 35 issues have been one of the most regular and constant features of the Vis Moot problems in the past seventeen years. Article 35 seeks to codify and fill the gaps on those aspects of sale of goods contracts which appear obvious to the parties (or one of the parties), but are likely to be the very cause of a dispute. As Honnold noted in his commentary ${ }^{148}$ :

Even a carefully prepared contract will often fail to express the most basic expectations - that a machine will operate or that a steel girder will be structurally sound - because the parties assume that these points are so obvious that they "go without saying" Consequently, courts and codifiers have had to try to describe, in general terms, those understandings that would have been written into the contract if the parties had drafted a contract provision to deal specifically with the question that led to dispute.

Article 35 is comprised of various elements. The first paragraph provides that the goods must conform to the requirements of the contract, and in particular, to be of the "quantity, quality, and description" and that they are contained or packaged in the manner required by the contract $^{149}$. The interesting aspect of paragraph 1 is that what constitutes requirements of the contract may be either express or implied ${ }^{150}$ and are to be determined by reference to Article $8^{151}$. In determining the implied requirements of the contract, various factors may be taken into account such as the standard business terms on which the contract is concluded, industry standards which may be relevant and applicable and the seller's advertising referring to

\footnotetext{
${ }^{147}$ Honnold, above $\mathrm{n} 39,253$.

148 Ibid, 252.

${ }^{149}$ Article 35(1). The full text of the CISG is set out in Appendix II.

${ }^{150}$ Schwenzer in Schlechtriem and Schwenzer, above n38, 413; Also see Enderlein and Maskow, above n70, Art 35, note 1 .

${ }^{151}$ Bundesgericht 22-Dec-2000, 4C.296/2000, Switzerland.
} 
particular qualities of the goods being sold ${ }^{152}$. Any discrepancy in quantity, whether more or less than what was agreed, quality (generally defined to be "as well as the goods' physical condition, all factual and legal circumstances concerning the relationship of the goods to their surroundings" 153 ), nature or agreed packaging requirements constitutes a lack of conformity in terms of Article 35(1). The buyer must give notice to the seller in accordance with Article 39 that any such lack of conformity exists. In cases where the application of Article 35(1) analysis does not render an evident answer as to whether the goods conform to the contract due to the contract not containing sufficient details, Article 35(2) provides objective criteria to be used in determining the goods' conformity, or lack thereof ${ }^{154}$. These criteria are: fitness for the purpose for which the goods would ordinarily be used (sub-paragraph (a)), fitness for a particular purpose (sub-paragraph (b)), possessing the qualities of a sample or model (sub-paragraph (c)), and that goods be contained and packaged in a manner usual for such goods (sub-paragraph (d)). Subparagraphs (a) and (d) will always apply to contracts subject to the CISG unless the parties have agreed otherwise, while sub-paragraphs (b) and (c) will only apply in particular factual situations relevant to the rules contained therein. Under Article 35(3) the seller is excluded from liability where the buyer "knew or could not have been unaware" of the lack of conformity at the time of the conclusion of the contract. The rule in sub-paragraph (b) includes a particular purpose which was either explicitly or impliedly made known to the seller. It also contains an important exclusion, namely where the "circumstances show that the buyer did not rely, or that it was unreasonable for him to rely, on the seller's skill and judgment".

As may be ascertained by considering the structure and the wording of the Article 35 rule, it is a very comprehensive mechanism for ascertaining lack of conformity. There are numerous reported decisions applying Article 35 which provide good guidance in its application. In its case law digest on Article 35 UNCITRAL considers some 83 decisions ${ }^{155}$, while the Pace Law database contains around 380 decisions. This is comparatively a very large amount of sources on Article 35 application. The Vis Moot has witnessed many Article 35 discussions in

\footnotetext{
${ }^{152}$ Schwenzer in Schlechtriem and Schwenzer, above n38, 413.

${ }^{153}$ Ibid, 414.

154 Ibid, 416.

${ }^{155}$ UNCITRAL Digest of case law on the United Nations Convention on the International Sale of Goods Digest of Article 35 case law; available at: http://www.cisg.law.pace.edu/cisg/text/digest-art-35.html (last updated June 30, 2009).
} 
keeping with this trend. Whether the goods were in conformity with the contract was an issue in the second, eleventh, thirteenth, fourteenth, fifteenth, and the seventeenth Vis Moot (which is to be discussed in Vienna next year). Non-conformity of the goods as a platform for other issues has also been in the backdrop of the fact scenarios in the third, fourth and sixteenth Vis Moot problems. The earlier Vis Moot problems, in particular the second, eleventh and thirteenth Vis Moots raised Article 35 issues in a general manner - by providing facts which allowed the parties to argue various tests of Article 35 in the alternative and explore their application in a wide context, while the latest problems, namely fourteenth, fifteenth and seventeenth Vis Moots, have presented a very specific aspect of Article 35 that has come to the fore in the recent years, namely issues concerning compliance with domestic regulations. It is evident that these issues, despite having arisen twice in the Vis Moot (in the fourteenth and fifteenth years) and having been discussed by scholars, are nonetheless still a "hot topic", as they are featured again, from a different angle, in the current (seventeenth) Vis Moot. This may be a result of a recent decision and the subsequent opinions in this area, which will be discussed further below, that have reconsidered issues of domestic regulations in terms of conformity requirements. This topical evolution of the Vis Moot scenarios parallels the evolution of jurisprudence on Article 35. This chapter will consider how various Article 35 issues have been explored throughout the years of the Vis Moot.

(b) Immaterial discrepancies as a type of non-conformity

Article 33(2) of the UNCITRAL Uniform Law on the International Sale of Goods (1964) ("ULIS") provided that "no difference in quantity, lack of part of the goods, or absence of any quality or characteristic shall be taken into consideration where it is not material". This was deliberately omitted from Article 35 CISG by its drafters as it was considered that such a rule would not be justified where the avoidance of the contract is only possible in the event of fundamental breach ${ }^{156}$. A discrepancy in the goods, although immaterial, will still amount to

156 See the comments on the match-up of Article 35 CISG with Article 33 ULIS at http://www.cisg.law.pace.edu/cisg/text/matchup/matchup-u-35.html. Also see Schlechtriem and Schwenzer, above n37, 284. 
non-conformity for the purposes of Article $35^{157}$, however it will not trigger the buyer's ability to avoid the contract or claim substitute goods but will be limited to damages (where the discrepancy reduces the value of the goods and the buyer consequently suffers loss). The CISG does not define what constitutes an "immaterial" discrepancy. The Concise Oxford Dictionary ( $9^{\text {th }}$ edition) defines "immaterial" as "of no essential consequence, unimportant". It is questionable whether the dictionary definition of the word "immaterial" is in fact the intended definition for the purposes of the application of the CISG. If it were, it appears the threshold would be very low. It is likely that an "immaterial" discrepancy, which still leads to a breach of contract under article 35 , will be something more than "of no essential consequence" but something less than a breach that would be fundamental under article 25 . According to Neumayer and Ming "a discrepancy is immaterial if it does by no means affect the utility or the value of the goods" "158. However, a recent decision of Appellationsgericht Basel-Stadt of 22 August 2003 held that where the non-conformity is of crucial significance to the buyer, although objectively immaterial, it may amount to a fundamental breach and the buyer will be able to avoid the contract under Article 49(1) or claim delivery of substitute goods under Article $46(2)^{159}$. The second Vis Moot explored this precise point nine years prior to this decision.

In the second Vis Moot Claimant and Respondent concluded a contract for the sale of one hundred and twenty A-14 resonators. Claimant had ordered A-14 resonators from respondent regularly in the past, although it had not ordered any in the six months prior to the conclusion of the contract in dispute. Upon receiving the A-14 resonators, Claimant carried out routine testing. The problem is not explicit on whether any issues were found to exist with the A-14 resonators during the routine testing, but it may be deduced that there were none. Upon completing the routine testing Claimant proceeded to assemble its mobile base stations, of which A-14 resonators were one component. The assembled mobile base stations were sold to a Claimant's customer. Upon purchasing the mobile base stations, the customer tested them and determined

\footnotetext{
${ }^{157}$ Schwenzer in Schlechtriem and Schwenzer, above n38, 425. Also see: Handelsgericht des Kantons Zürich 30 November 1998 (Lambskin coat case), Switzerland.

${ }^{158}$ Karl Neumayer and Catherine Ming Convention de Vienne sur les Contracts de Vente Internationale de Merchandise CEDIDAC, Lausanne 1993, Article 35, para 2.

${ }^{159}$ See Appellationsgericht Basel-Stadt, 22 August 2003 (Soyprotein products case), Switzerland, where the food which was held to be free of genetically modified soybeans was found to have $0.1 \%$ to $1 \%$ of it genetically modified, the Court held that this amounted to a fundamental breach in the circumstances.
} 
that they did not work properly in "certain rare, but important situations"160. Investigations were carried out to determine where the issue lay, and it was concluded that the problems were caused by the A-14 resonators. Claimant subsequently discovered that Respondent had made modifications to the A-14 resonators without having informed Claimant. These modifications did not alter the resonators published technical specifications but it did render them incompatible with components of Claimants mobile base stations in certain situations.

Unfortunately the memoranda for the parties are no longer available from this year of the competition, but it can be deduced from these facts what arguments would have been presented. This scenario appears to fit perfectly within the principle embodied in the recent decision of Appellationsgericht Basel-Stadt of 22 August 2003 discussed above. However, at the time this problem was presented, the rules only reached as far as to hold that "immaterial discrepancies will never amount to a fundamental breach of a contract" ${ }^{\prime 161}$. In this example, therefore, the parties could, and probably did, still run arguments on whether the modification made to A-14 resonators amounted to an immaterial discrepancy, or whether it would come under any of other tests of Article 35. It would be difficult for Claimant to argue non-conformity under Article 35(1), as the quality and quantity do not appear to have been affected. Likewise, it would be difficult to argue Article 35(2)(a) in terms of ordinary uses of the goods of the same description. Some argument may be advanced in terms of Article 35(2)(b) in that the seller knew that the A14 resonators would be used in the mobile base stations and, as such, was aware of their particular purpose. Whichever angle may have been taken, the fact that a minor modification which did not affect technical specifications amounted to an immaterial discrepancy stands as the most persuasive take on these facts. This problem identified the gap in the approach to immaterial discrepancies, namely that a defect, although objectively minor, may be of a particular consequence to the buyer, and where this is the case, fundamental breach (leading to either avoidance or a claim for substitute goods) may be the result. The decision of Appellationsgericht Basel-Stadt may be a step in the right direction, although the decision may benefit from a scholarly opinion that will develop this concept further. For example, is a test required to ascertain whether the seller was aware, or whether a reasonable person in the seller's

\footnotetext{
${ }^{160}$ Second Vis Moot Problem, 5.

${ }^{161}$ Schwenzer in Schlechtriem and Schwenzer, above n38, 284.
} 
position should have been aware of an immaterial discrepancy that would be of crucial significance to the buyer.

Two of winning memoranda from the fourteenth Vis Moot had a brief exchange of arguments on this point ${ }^{162}$. Claimant and Respondent concluded a contract for the sale of five distribution fuse boards. Attached to the contract were engineering drawings containing two descriptive notes requiring "Chat Electronics JP type" fuses. Eventually Respondent delivered "JS type" fuses and Claimant's contractors refused to connect them to the electrical power grid $^{163}$. Among multiple other submissions as to the conformity of JS type fuses to the contract, Respondent ran the argument that the difference between JP and JS type fuses was immaterial. It argued that "in general, the discrepancy between actual and contractual condition of the delivered goods constitutes a lack of conformity" but that an exception is made in the case of immaterial discrepancies; and that "strict formalism in regard to immaterial discrepancies would ignore the reality of business life" 164 . Its argument was focused around showing that the discrepancy was immaterial, and that as such, the delivery of JS type fuses was in conformity with the contract. This conclusion does not appear entirely consistent with the general view that, even an immaterial discrepancy constitutes non-conformity, and therefore a breach of contract ${ }^{165}$. The argument, possibly, should have been focussed on availability, or lack of, remedies for a breach involving an immaterial discrepancy. Claimant only made a fleeting reference to the arguments concerning whether the discrepancy was immaterial. It merely concluded that the difference was not immaterial based on the facts ${ }^{166}$, and dismissed this point accordingly. Therefore, regrettably, the Vis Moot has not explored this issue further, nor have the parties delved into the potential arguments concerning situations where an immaterial discrepancy is of crucial importance to the buyer and should therefore amount to fundamental breach. This topic, perhaps, is one that will be re-visited in the future years of the competition.

\footnotetext{
${ }^{162}$ Interestingly, it was only the winning memoranda submitted by the University of Freiburg that touched on this issue.

${ }^{163}$ For a full summary of the facts please refer to Appendix 1.

${ }^{164}$ Albert Ludwigs Universität Freiburg, Memorandum for Respondent, Fourteenth Vis Moot, 11.

${ }^{165}$ Schwenzer in Schlechtriem and Schwenzer, above n38, 425.

${ }^{166}$ Albert Ludwigs Universität Freiburg, Memorandum for Claimant, above n164, 14.
} 
(c) General exploration of the interoperability of paragraphs 1 and 2 of Article 35

The UNCITRAL case law digest on Article 35 observes $^{167}$ :

A seller's breach of its obligations under article 35, furthermore, can in proper circumstances rise to the level of a fundamental breach of contract as defined in article 25 of the Convention, thus justifying the buyer in avoiding the contract under article 49 (1) of the Convention.

This classic example of an Article 35 scenario was explored in the eleventh Vis Moot. The eleventh Vis Moot is an excellent demonstration of a general application and interpretation of various tests in Article 35. Claimant and Respondent concluded a contract for the purchase by Claimant of six Model 14 auger-feeder machines (from here on referred to as "machines") used for packaging "dry bulk commodities". Claimant encountered two issues with these machines; the first that they were unable to package salt - those of the machines Claimant used for packaging salt quickly corroded and were rendered useless; and they were allegedly packaging at slower speeds than was expected. Claimant therefore pleaded that the machines were not in conformity with the contract on the following grounds: they were not of the quality required by the contract in that they could not package salt (Article 35(1)); they were not fit for a particular purpose of packaging salt (Article 35(2)(b)); they were not fit for their ordinary use (which included the ability to package salt - Article 35(2)(a)); the machines were not of an average quality due to the slow speeds at which they performed (Article 35(1)) and that the machines did not perform at speeds that could ordinarily be expected (Article $35(2)(a))^{168}$. The main argument concerned the ability to package salt, and the issue of speed was subsidiary. The factual controversy arose from the reasonably vague description of goods required by Claimant, as it requested machines "capable of packaging dry bulk commodities... over a wide range of products, both fine goods, such as ground coffee or flour, and coarser goods such as beans or rice" 169 . Salt was not explicitly mentioned by Claimant in its request. What is particularly interesting about this problem is that the arguments for each side were so perfectly balanced that both parties argued each element of Article 35 with equal strength and support of authorities. For example, Article 35(1): Respondent argued that the machines were indeed capable of "packaging

\footnotetext{
${ }^{167}$ UNCITRAL Digest of case law on the United Nations Convention on the International Sale of Goods Digest of Article 35 case law, available at: http://www.cisg.law.pace.edu/cisg/text/digest-art-35.html (last updated June 30 , 2009).

${ }^{168}$ See for example University of Heidelberg, Memorandum for Claimant, Eleventh Vis Moot.

169 Eleventh Vis Moot Problem, Claimant Exhibit 1
} 
a wide range of products", including all those mentioned by Claimant in its request, and as such conformed to the contract in respect of quantity, quality and nature. Claimant argued that its broad request meant all types of "dry bulk products" are captured, including corrosive ones such as salt, and that without limitation of such a broad range by either party the machines "could be assumed to package all dry bulk commodities without limitation",170. Respondent argued that machines were fit for their ordinary use in terms of Article 35(2)(a), and that packaging salt was not such an ordinary use given its corrosive qualities ${ }^{171}$. Claimant relied on the opinion that it is sufficient that the particular purpose is made to the seller implicitly under Article $35(2)(b){ }^{172}$ and that a "reasonable seller could have recognised the purpose in the circumstances and the buyer relied on seller's skill and judgment"1733. As such it argued that the requirement for packaging a "wide range of products", in the circumstances and given Respondent's specialist knowledge in respect of packaging machines, sufficiently implied the requirement for packaging salt into the agreement $^{174}$. This problem is a very useful guide on Article 35 in various ways. Initially, it provides an excellent overview of the manner in which Article 35 analysis is carried out in respect of each of its various tests. Secondly, it is a very interesting problem in the sense that it provides meticulously drafted facts which allow for perfectly balanced arguments on both sides. The equally persuasive arguments on both sides are a good demonstration of the imperfection of general rules which will need to be adapted to specific factual scenarios. Perhaps the "obvious" aspects of the contract that "go without saying" which have led to the dispute in the first place, as discussed above, will be difficult to ascertain in certain circumstances even with the aid of the rules set out in Article 35 .

(d) Specific issues arising under paragraphs (a) and (b) of Article 35(2)

The eleventh Vis Moot (as well as the thirteenth) explored the application of Article 35 in relatively general terms, with the facts designed in such a way as to allow for the discussion to consider the general principles embodied in this provision. The fourteenth and fifteenth Vis Moots raised more specific issues and focussed the debate on rather new areas of application of

\footnotetext{
${ }^{170}$ University of Heidelberg, Memorandum for Claimant, Eleventh Vis Moot, 16.

${ }^{171}$ National University of Singapore, Memorandum for Respondent, Eleventh Vis Moot, 6.

${ }^{172}$ Landgericht München, 27 Feb 2002 (Globes case), Germany.

${ }^{173}$ Schlechtriem and Schwenzer, above n38, 422.

${ }^{174}$ University of Heidelberg, Memorandum for Claimant, above n1 70, 15-16.
} 
Article 35(2). As will be discussed further below, the upcoming seventeenth Vis Moot takes this specific topic one step further. The fourteenth Vis Moot concerned whether the goods delivered had to be in conformity with the relevant regulations in the buyer's country. The fifteenth Vis Moot explored whether the goods sold were fit for ordinary, as well as particular, purposes given an intervening publication of newspaper articles containing various assertions as to the quality of the goods. The seventeenth Vis Moot includes issues as to changing regulations in the country of a third party where the goods will eventually be used by the buyer. These examples are discussed below in light of recent developments on each of these aspects of Article 35(2).

(e) Quality standards in the buyer's jurisdiction \& requirements of Article 35(2)

Article 35(2)(a) generally requires that goods be "fit for the purpose for which they would ordinarily be used". A particular aspect that has been the subject of much debate is the issue whether the quality standards or laws and regulations in the buyer's jurisdiction are relevant when determining whether the goods are in conformity with the contract under Article $35(2)(a)^{175}$. The scholarly and jurisprudential opinions seem to vary. The Court in the Mussels Case $^{176}$, where the buyer bought mussels which contained cadmium levels exceeding the recommendations of the health regulations in the buyer's country held that, although the mussels did not meet the quality standards in the buyer's country, they were in conformity with the contract in terms of Article $35(2)(a){ }^{177}$. The Court reasoned that ${ }^{178}$ :

\begin{abstract}
a foreign seller can simply not be required to know the not easily determinable public law provisions and/or administrative practices of the country to which he exports, and ... the purchaser, therefore, cannot rationally rely upon such knowledge of the seller, but rather, the buyer can be expected to have such expert knowledge of the conditions in his own country or in the place of destination, as determined by him, and, therefore, he can be expected to inform the seller accordingly.
\end{abstract}

This decision therefore imports the obligation on the seller to comply with the relevant standards in the buyer's country where the buyer informed the seller of those standards, and they

\footnotetext{
${ }^{175}$ See Schwenzer in Schlechtriem and Schwenzer, above n38, 418; also UNCITRAL Digest of case law on the United Nations Convention on the International Sale of Goods Digest of Article 35 case law, available at: http://www.cisg.law.pace.edu/cisg/text/digest-art-35.html

${ }^{176}$ Bundesgerichtshof 8 March 1995, Germany (Mussels Case).

${ }^{177}$ Ibid.

${ }^{178}$ Ibid, at para II.1.b),bbb).
} 
consequently became a requirement under the contract. Also, it may be understood that where the standards are the same in the seller's and buyer's country, the seller will be expected to comply with them. Certain subsequent decisions have held that sellers may be required to comply with standards in the buyer's country where buyer did not explicitly inform the seller of such standards under "special circumstances", for example where the parties had previous dealings which indicated that the seller must have been aware of such standards ${ }^{179}$. Essentially, however, Schwenzer pointed out that "the question of the relevant standard is a matter of the interpretation of the contract" ${ }^{180}$. This point is very well illustrated in the example of the fourteenth Vis Moot.

The fourteenth Vis Moot problem tackled this issue. The parties concluded a contract for the sale of five distribution fuse boards. Attached to the contract were drawings containing descriptive notes that read: "fuses to be Chat Electronics JP type" and "lockable to Equalec requirements" 181 . Respondent, after a brief consultation with one of Claimant's employees, agreed to deliver JS type fuses (from Chat Electronics) instead, as JP type from Chat Electronics were at that time unavailable. The electrical supply distribution company in Claimant's jurisdiction, "Equalec", refused to connect JS type fuses to the electrical grid due to them failing to meet its safety standards. Among multiple other issues in this problem, a dispute arose as to whether JS type fuses were in conformity with the contract in terms of their non-compliance with Equalec's requirements. Claimant generally argued that the explicit reference in the descriptive notes that the fuses must be "lockable to Equalec requirements" was sufficient to inform Respondent of the need for the fuses delivered to comply with the requirements and standards of Equalec, and be of the type and quality that Equalec would connect to the electric grid ${ }^{182}$. It referred to the decision in the Mussels Case as supporting this proposition, and in particular the rule set out in that decision that where the buyer explicitly pointed a particular requirement to the seller, the seller must ensure the goods delivered comply with it. The gist of its argument was that supplying the phrase "lockable to Equalec requirements" on the descriptive note was such an

\footnotetext{
${ }^{179}$ Magellan International v. Salzgitter Handel GmbH, No. 99 C 5153 United States District Court for the Northern District of Illinois, Eastern Division December 7, 1999, United States; and Cour d'appel, Grenoble 13 September 1995, France.

${ }^{180}$ Schwenzer in Schlechtriem and Schwenzer, above n38, 418.

${ }_{181}^{181}$ Fourteenth Vis Moot Problem, Notice of Arbitration, para 9.

${ }^{182}$ See Albert Ludwigs Universität Freiburg, Memorandum for Claimant, Fourteenth Vis Moot, in particular paragraphs 54-80.
} 
explicit reference to a particular standard. This explicit reference was further supported by the proposition that Respondent could not have been unaware of the standards in the buyer's jurisdiction in light of the relevant circumstances. As such, Claimant relied on the decision in Magellan International v. Salzgitter Handel ${ }^{183}$ where the standards required were only impliedly made known to the seller, and it was held that the seller could not have been unaware of them. Respondent suggested a rather semantic view of the phrase "lockable to Equalec requirements", by interpreting it as meaning that the fuses only needed to be locked by the padlock by Equalec $^{184}$. In a very conceptual manner, Claimant refuted this argument by submitting that ${ }^{185}$ :

\begin{abstract}
...even if one considered the word "lockable" merely as a reference to the padlock that Equalec is to put on the boards to ensure its exclusive access to them... the consequence would be the same: Equalec would lock fuse boards with a padlock only if it had previously connected them to the electric grid... Without its requirements being fulfilled, Equalec would neither connect nor padlock any fuse board.
\end{abstract}

Claimant also confronted Respondent's allegation in the problem that the restriction set by Equalec was contrary to the law. It argued that the principle of party autonomy enabled them to agree on restrictions between them, and that given the importance of the need for the fuses to comply with Equalec's requirements in terms of the satisfaction of Claimant's broader contractual obligations, "the legitimacy of the standard was of no importance". ${ }^{186}$

Respondent submitted that in terms of Article 35(2)(b), any particular purpose requires the seller to be informed of it in a "crystal clear and recognisable way"187. The gist of Respondent's argument, unsurprisingly, is that Claimant did not make known to Respondent, neither expressly or impliedly, that the fuse boards had to conform to a specific standard, ie Equalec's policy. This general premise was supported by various arguments and facts, for example that the mere mention of the firm Equalec on the descriptive note is insufficient to indicate in a "crystal clear and recognisable way" that compliance with their policy is required. As such, it was up to

\footnotetext{
${ }^{183}$ Magellan International v. Salzgitter Handel GmbH, No. 99 C 5153 United States District Court for the Northern District of Illinois, Eastern Division December 7, 1999, United States.

${ }_{184}$ Albert Ludwigs Universität Freiburg, Memorandum for Respondent, Fourteenth Vis Moot, para 47-50.

${ }^{185}$ Albert Ludwigs Universität Freiburg, Memorandum for Claimant, Fourteenth Vis Moot, para 66.

${ }^{186}$ Ibid, para 65.

${ }^{187}$ Albert Ludwigs Universität Freiburg, Memorandum for Respondent, above n1 84, para 55; relevant authorities in support of this point that were relied on include: Landgericht Darmstadt, 9 May 2000 (Video recorders case), Germany; Landgericht München, 27 February 2002 (Globes case), Germany; and the Secretariat Commentary on Article 35 , at para 8 .
} 
Claimant to ensure that Respondent was aware of the special provisions applying in its jurisdiction and incorporate them into the contract. Interestingly, Respondent also relied on the decision in the Mussels Case, except in support of its proposition that the seller cannot be expected to be aware of the public law standards in the buyer's country, and that, given the reference on the descriptive note was insufficient to draw Respondent's attention to particular requirements, there was no obligation on it to comply with Equalec's policy.

The above example illustrates yet another well drafted problem where both sides may rely on the exact same authorities and interpretation and put forward equally convincing opposing arguments. The essence of the above example goes to demonstrate that, indeed, determining what the relevant applicable standard is eventually a matter for the interpretation of the contract ${ }^{188}$. At the heart of the above arguments was a purely factual issue - did the reference in the descriptive note suffice so as to require Respondent to ensure the goods comply with Equalec's policy? Certainly, the vast amount of jurisprudence that has developed over the recent years is a necessary framework of reference for the parties and the judges determining such questions of fact in light of Article 35 requirements.

(f) Public allegations impacting merchantability of the goods - from the Mussels case to the Frozen pork case

This section explores a subset of the above issue concerning relevant applicable standards. It considers the issues of conformity in terms of situations where regulations may or may not exist at the time of the conclusion of the contract, yet the goods may nonetheless not be in conformity in terms of the objective standards set out in Article 35(2).

For the goods to be fit for their "ordinary purpose" under Article 35(2)(a) they must be, primarily, fit for commercial purposes, meaning it must be possible to resell them ${ }^{189}$. Whether the ability to resell them is in itself sufficient for them to be in conformity with the contract in terms of Article 35(2) is not entirely clear. Different courts have applied different standards, for

\footnotetext{
${ }^{188}$ Bundesgerichtshof 8 March 1995 (Mussels case), Germany.

${ }^{189}$ Schwenzer in Schlechtriem and Schwenzer, above n38, 416.
} 
example in the Mussels Case it was raised, although left unresolved, whether Article 35(2)(a) requires that goods be of "average quality" or merely of "marketable quality". ${ }^{190}$ Although in a different decision it was held that goods must be of "average" quality and not "merely marketable"191, while a decision of the Netherlands Arbitration Institute rejected both "average quality" and "merchantability" and applied a standard of "reasonable quality"192. The concept of "merchantability" comes from the English common law, and in its common law meaning has been rejected as the standard to be used under Article 35(2)(a) CISG $^{193}$. The applicable standard has shifted recently to the "reasonable, or justifiable, expectations of the buyer" 194 . The above section considered the rules surrounding applicability of laws and regulations in the buyer's country. The general rule established in the Mussels case embodies the overall principle that the seller does not have to comply with the buyer's local law requirements in order to meet the objective standards of conformity captured in Article 35(2). However, a new subset of issues emerges when questions of compliance with local laws and regulations is paired with the principle of goods being capable of being resold, namely of the standards of minimum quality required of the goods under Article 35(2), as discussed above. A grey area between the requirement of goods' merchantability and the applicability of standards in the buyer's country has emerged in a recent German decision known as the Frozen Pork case ${ }^{195}$. In this case, a German buyer entered into a contract with a Belgian seller for the purchase of pork, which was to be delivered in instalments directly to the buyer's customer for forwarding to the ultimate buyer in Bosnia-Herzegovina. The goods arrived in Bosnia-Herzegovina on 4 June 1999, and the seller's invoices were payable by 25 June 1999 at the latest. During June 1999, a suspicion that Belgian pork may be contaminated with dioxin started to arise in both Belgium and Germany. In Germany an ordinance was enacted on 11 June declaring Belgian pork as not marketable without a health clearance certificate stating the meat did not contain any dioxin was obtained. In Belgium a similar ordinance was passed on 28 July. Buyer sought a health certificate from the Belgian seller but did not obtain it. The buyer refused to pay the full purchase price since Bosnia-

\footnotetext{
${ }^{190}$ Bundesgerichtshof 8 March 1995 (Mussels Case), Germany.

${ }^{191}$ Landgericht Berlin 15 September 1994 (Shoes case), Germany.

${ }^{192}$ Netherlands Arbitration Institute, Award 2319, 15 October 2002.

${ }^{193}$ Schlechtriem and Schwenzer, above $38,418$.

${ }^{194}$ Ibid, the concept of "merchantable" has been replaced with that of "satisfactory condition" in the Sale of Goods Act 1994 (UK).

${ }^{195}$ Bundesgerichtshof, 2 March 2005, [VIII ZR 67/04] (Frozen pork case), Germany.
} 
Herzegovina also prohibited resale of Belgian pork, and since the buyer could not procure the health certificate customs have held, and subsequently disposed of the meat. The Court held, inter alia $^{196}$ :

\begin{abstract}
...that in international wholesale and intermediate trade the resaleability (tradability) of the goods is one aspect of being fit for the purpose of ordinary use in terms of article 35(2)(a) CISG and that in the case of foodstuff intended for human consumption, the resaleability includes that the goods are at least not harmful to health. Insofar as this is governed by provisions of public law, the law of the seller's state is applicable on principle. Furthermore, the Federal Court held that in the sector of international wholesale and intermediate trade, the mere suspicion that the goods may be harmful to health represents a lack of conformity of the goods and therefore a breach of contract at any rate, if the suspicion has resulted in measures of public-law precluding the tradability of the goods. (emphasis added)
\end{abstract}

This decision is of particular interest, as it seems to deal with a gap in application of the conformity provisions. On the one hand it holds that a mere suspicion that the goods may be harmful to health represents a lack of conformity, however it still goes on to require that publiclaw measures, whether in the seller's or the buyer's country, are enacted to deal with such a suspicion. It is unclear whether the existence of such public-law measures is a necessary component for the goods not to be in conformity in terms of Article 35(2). The Schlechtriem Commentary suggests that this is not the case, as it contains the following statement in reference to this decision 197: "Food must be fit to eat, even reasonable suspicion that the food may be contaminated constitutes a lack of conformity". This is confirmed by Schlechtriem's observations that ${ }^{198}$ :

\begin{abstract}
The decision elegantly avoids an open overruling of the holding in the Mussels case, but it cannot really conceal the change in direction: if non-merchantability of the Belgian meat in European countries was caused already by the suspicion of its dioxin-contamination (and, therefore, non-conformity existed before the passing of risk), then the Belgian regulation and the date of its issuance, i.e., the public law requirements of Belgian law, did not matter at all. (emphasis added)
\end{abstract}

Schlechtriem provided a very thorough opinion on this decision, and concluded that the rule which the decision in fact embodies is that the mere existence of a suspicion that the food

\footnotetext{
${ }^{196}$ From the English abstract prepared by Prof. Ulrich Magnus, National Correspondent, and Jan Lüsing for the Pace Law Database, available at: http://cisgw3.law.pace.edu/cases $/ 050302 \mathrm{gl}$.html

${ }^{197}$ Schlechtriem and Schwenzer, above n38, 417.

${ }^{198}$ Peter Schlechtriem "Commentary - Compliance with local law; seller's obligations and liability, Annotation to German Supreme Court decision of 2 March 2005 [VIII ZR 67/04]", available at: http://www.cisg.law.pace.edu/cisg/biblio/schlechtriem7.html
} 
contains ingredients harmful to human health which renders it unfit for any resale is in itself nonconformity. Schlechtriem considers that, whether the suspicion was founded or not is of no relevance in terms of determining the conformity of such goods ${ }^{199}$. In particular Schlechtriem concluded that ${ }^{200}$ :

\footnotetext{
Public law reactions to such a suspicion only facilitate the proof of the suspicion and of its consequences for the conformity or non-conformity of the goods. Since such suspicions occur frequently and - often - are widely spread by the media, the decision is of great importance for such situations. And one waits with great interest for a case, where the Supreme Court will have to decide on a suspicion, which has not led to public law regulations, but has, nevertheless, infringed the merchantability of the suspected goods. (emphasis added)
}

A couple of years after the decision in the Frozen Pork case and the above opinion on its application from Schlechtriem, the fifteenth Vis Moot, not entirely surprisingly, introduced an issue corresponding precisely to the scenario envisaged by Schlechtriem which involved a suspicion as to the safety of a particular product, but did not result in any public law regulations.

In the fifteenth Vis Moot Claimant and Respondent negotiated a contract for the sale of 20,000 cases of "Blue Hills 2005" wine (referred to from here on as "the wine") by Claimant to Respondent. The wine was to be used by Respondent as a leading feature in a wine promotion. However, shortly before the conclusion of the contract the newspapers in Respondent's jurisdiction had reported that anti-freeze had been used to sweeten the wine produced in the same region where Blue Hills 2005 had been produced. Respondent attempted to revoke its offer to purchase the wine, although such revocation was one of the issues in dispute. The secondary issue was, should it be held that the contract was indeed concluded, whether the wine was in conformity with the contract given the newspaper allegations. The allegations did not lead to any public law regulations, and according to subsequent expert opinions obtained as evidence in the arbitration, the adding of anti-freeze in small quantities as was the case with Blue Hills 2005, was not harmful to human health. Respondent argued that the wine did not conform with the standard of quality required under the contract which involved a fine wine promotion. It also argued that the wine did not conform to a particular purpose of a leading promotional wine due to the "contamination and of its bad reputation after the broad media coverage of the wine

\footnotetext{
${ }^{199}$ Ibid.

200 Ibid.
} 
scandal in the Blue Hills region"201. It based the argument on two key pillars, namely that the quality of the wine is not in conformity with the contract; and that its reputation in Respondent's country is not in conformity in terms of Article 35. It argued that a wine which contained additives, and in particular a toxic substance (diethylene glycol) cannot amount to a "quality wine suitable to lead a wine promotion", since the presence of such toxic additives indicates it is a low quality product ${ }^{202}$. Respondent cited the above conclusion from the Schlechtriem Commentary, namely that "food must be fit to eat; even a reasonable suspicion that the food may be contaminated constitutes a lack of conformity" ${ }^{203}$ and then continued to apply the decision in the Frozen Pork case. It relied on the decision consistently with Schlechtriem's interpretation and the rendering of the rule in the Schlechtriem Commentary, namely that the mere existence of a suspicion of contamination indicates there is a fault and it is up to the seller to prove this is not the case ${ }^{204}$. Based on this principle, Respondent concluded that the wine was not in conformity with the contract since Claimant failed to show it contained anti-freeze, and quite to the contrary, its expert witness confirmed the presence of a toxic anti-freeze substance and that a controversy indeed exists as to the amount which may be safely consumed ${ }^{205}$. Claimant also relied on these principles in providing its opposing arguments. It argued that, based on the evidence presented, the wine was safe to drink since only small amounts of anti-freeze substance were added, which did not contaminate $\mathrm{it}^{206}$. It also considered various different standards to which the goods must conform in terms of Article 35(2)(a), and submitted that the wine was "of reasonable quality", and noted that "in the absence of internationally-accepted fixed standards" an objective standard should be the starting point ${ }^{207}$. As such it concluded its argument on the premise that the wine was in conformity with most of the different tests under Article 35(2)(a), in that it was of a "higher standard than that required to be capable of resale", in that it is both an award wining wine, as well as it being safe for consumption ${ }^{208}$. Claimant's arguments appear only to take on half the test relevant in this case. Application of Article 35(2)(a) in terms of "reasonable" or "merchantable" quality is only one relevant aspect in terms of this product's conformity under

\footnotetext{
${ }^{201}$ Ruprecht Karls Universität Heidelberg, Memorandum for Respondent, Fifteenth Vis Moot, 2.

202 Ibid, 29.

${ }^{203}$ University of Geneva, Memorandum for Respondent, Fifteenth Vis Moot, 33

${ }^{204}$ Ibid.

205 Ibid.

${ }^{206}$ University of California, Berkley School of Law, Fifteenth Vis Moot, 24.

207 Ibid.

${ }^{208}$ Ibid, 25.
} 
the circumstances. Respondent applied the second limb, namely the principle in the Frozen Pork case, and in a manner that is consistent with Schlechtriem's interpretation of that decision. This may be a positive sign that this interpretation has been accepted as the leading principle, and that it will be applied as such in future disputes of a similar nature. As Schlechtriem noted, "one waits with great interest" ${ }^{209}$ for a decision which will tackle these issues and confirm this approach.

\section{(g) Legal analysis}

Article 35 has been subject to a voluminous amount of jurisprudential analysis over the years and the growth in its application and interpretation is a great testament to the jurisprudential development of the CISG. It is evident from the above analysis that, while the rules on non-conformity lie at the heart of sale of goods disputes and are thus likely to commonly arise, the jurisprudence on the core principles of Article 35 and its application is reasonably robust. The current concerns arising out of the application of this provision chiefly concern very sophisticated and specific issues which have arisen, for example in respect of considerations of relevant public law regulations which ought to apply, or the interaction between public allegations arising suspicions relating to the quality of goods sold versus their actual conformity with the contract. The Vis Moot casebook on Article 35 is a good illustration of the evolution of jurisprudence in this area, as it moves through explorations of general doctrines which have been more or less settled over time and rather markedly shifts towards specific, complex and in-depth factual scenarios designed to consider very narrow and problematic aspects of the provision's application in the current context.

\footnotetext{
${ }^{209}$ Schlechtriem, above n 197.
} 
(a) Introduction

Avoidance is a remedy for breach of contract which terminates the contract and releases the parties from their obligations under the contract. Avoidance under article 49 is possible either where a fundamental breach occurs (in accordance with Article 25) or where the seller does not deliver the goods within additional period of time fixed by the buyer (in accordance with Article $47(1)$ ), subject to the seller's right to cure defects in performance in accordance with Articles 37 and $48^{210}$. Avoidance is only valid if "made by notice to the other party" in accordance with Article 26. One of the general principles of the CISG is that the contract preservation is preferred over contract avoidance and that prevention of a "particularly severe" remedy of contract avoidance should be prevented wherever possible ${ }^{211}$. Avoidance is considered as a remedy of last resort "that is available when the buyer can no longer be expected to continue the contract" ${ }^{212}$. The thresholds rendering a breach fundamental are consequently rather high. As may be expected in sales transaction, a party may prefer to cancel (avoid) the contract where things go wrong, however, whether it is entitled to do so will be a question of fact to be determined in reference to the tests in Article 25. Article 25 is of key importance in the CISG as it provides the tests for a breach of contract which allows for the termination of the duties and rights of both parties to "proceed further with performance, subject to a claim for damages for breach" ${ }^{213}$. It is this issue of the ability to avoid the contract where a fundamental breach has occurred that has received much attention over the years both from CISG scholars and through reported decisions. It is therefore this particular limb that will be explored in this chapter. As will

\footnotetext{
${ }^{210}$ Honnold, above $n 39,326$.

${ }^{211}$ Franco Ferrari "Fundamental Breach of Contract Under the UN Sales Convention - 25 Years of Article 25 CISG" 25 JL \& Com (Spring 2006) 489-508, 501; Joseph Lookofsky "1980 United Nations Convention on Contracts for the International Sale of Goods"; published in International Encyclopaedia of Laws - Contracts, Suppl. 29 December 2000, 1-192, 122; Peter Schlechtriem "Subsequent Performance and Delivery Deadlines - Avoidance of CISG Sales Contracts Due to Non-conformity of the Goods" 18 Pace Int'l L Rev, Issue No. 1 (Spring 2006) 83-98, 95.

${ }^{212}$ UNCITRAL Digest of case law on the United Nations Convention on the International Sale of Goods, Digest of Article 49 case law, para 2, available at: http:/www.cisg.law.pace.edu/cisg/text/digest-art-49.html (last updated on June 15, 2009). See also Bundesgerichtshof 3 April 1996, Germany; Oberster Gerichtshof 7 September 2000, Austria; Tribunale di Busto Arsizio 13 December 2001, Italy.

${ }^{213}$ Honnold, above $39,205$.
} 
be discussed further below, the Vis Moot scenarios are ripe with issues of fundamental breach as a precondition of avoidance.

There are two key elements to Article 25, the detriment to the party not in breach, and the test of foreseeability. For a breach to be considered "fundamental" with in the meaning of Article 25 it primarily must "result in such detriment to the other party as substantially to deprive him of what he is entitled to expect under the contract". This "substantial deprivation" is subject to the, both objective and subjective, tests of foreseeability, meaning it will apply where the party in breach did foresee, or a reasonable person of the same kind in the same circumstances would have foreseen such a result ${ }^{214}$.

The definition of fundamental breach is focussed on the detriment of the other party ${ }^{215}$. The first element of the fundamental breach test is therefore the "substantial deprivation" of what the party not in breach "was entitled to expect under the contract". Given the manner in which this test is framed, quantification or creation of specific parameters will not be relevant, rather the application of this test must be weighed as against the relevant facts in each case. An example used by Schlechtriem in the Commentary is that, where a fixed date for delivery is required by the buyer, "the contractually-based interest in taking delivery on that date is so fundamental" that the buyer may avoid the contract irrespective of the actual damage it suffered due to delayed delivery ${ }^{216}$.

The application of the foreseeability test has raised various issues over the years and has resulted in multiple opinions as to its application. Schlechtriem distinguished three basic scenarios in determining whether the foreseeability test will apply ${ }^{217}$. Firstly, in situations where the parties have clearly agreed in the contract that its particular term or aspect is of key importance the foreseeability test will be of no relevance if such an obligation is breached ${ }^{218}$. Similarly, where a particular obligation was discussed during negotiations and has been clearly identified as having a great importance, but has not been clearly incorporated into the contract,

\footnotetext{
${ }^{214}$ In Article 25 this is expressed in the negative, namely: "unless the party in breach did not foresee and a reasonable person of the same kind in the same circumstances would not have foreseen such a result". The full text of the CISG is set out in Appendix II.

${ }^{215}$ Honnold, above n39, 207.

${ }^{216}$ Schlechtriem and Schwenzer, above n38, 287.

${ }^{217}$ Ibid, 288-289.

218 Ibid, 288.
} 
subject to proof as to agreement on its importance, it will also render the foreseeability test irrelevant ${ }^{219}$. It is in those circumstances where ${ }^{220}$ :

the particular importance of the obligation breached has not been established in the contract itself, or not clearly put beyond doubt during the contract negotiations, can 'foreseeability' be relevant.

It is precisely in the cases that come within this third scenario that most problems of interpretation arise. In general, the parties will have to rely on interpretation aids in Article 8 to determine whether an obligation was established, or whether, in terms of Article 8(2) a reasonable person in the same type of business would have foreseen that a particular obligation carried a special importance given the relevant circumstances.

The test has been left deliberately ambiguous in terms of specifying the time at which the party should have foreseen the breach ${ }^{221}$. In contrast, Article 74 which contains the general rule for measuring damages quite explicitly provides "... which the party in breach foresaw or ought to have foreseen at the time of the conclusion of the contract..." (emphasis added) ${ }^{222}$. One reported decision does hold that the relevant time when the breach must be foreseeable is the time of the conclusion of the contract ${ }^{223}$. However, it has been observed that, whether this is the case or whether the relevant time is subsequent to the conclusion to the contract "so that the contract can be 'upgraded' is a matter of controversy among legal writers" 224 , although Schlechtriem agrees with the above decision that the relevant time is that of the conclusion of the contract $^{225}$ :

\footnotetext{
...by subsequently sending information (e.g. that he has agreed a penalty with his sub-buyers in the event of his late delivery), the promisee cannot pave the way to avoiding the contract should a breach occur which would not have been fundamental in the absence of such information
}

A consideration of the two tests of fundamental breach demonstrates that their application will be entirely dependent on the consideration of distinct factual scenarios. Over the years that the CISG has been in operation, various courts have developed rules in reference to general

\footnotetext{
219 Ibid.

${ }^{220}$ Ibid, 289.

${ }^{221}$ Honnold discusses this issue at length, above n39, 207.

${ }^{222}$ Article 74 CISG, full text of the CISG is set out in Appendix II.

${ }^{223}$ Oberlandesgericht Düsseldorf 24 April 1997, Germany.

${ }^{224}$ Schlechtriem and Schwenzer, above n38, 290.

${ }^{225}$ Schlechtriem and Schwenzer, above n38, 290.
} 
recurring scenarios ${ }^{226}$. The two main areas within which application of the fundamental breach tests has been contentious are cases of breach where the goods delivered are not in conformity with the contract and cases where the delivery of the goods is either partial, delayed or does not occur at all ${ }^{227}$. These two areas are clearly mirrored in the issues presented throughout the Vis Moot problems and will be explored in this chapter. Article 25 has been the subject of a vast amount of commentary, and has featured in the fifth, seventh, eight, tenth, eleventh, twelfth, and sixteenth years of the Vis Moot. The key question which arises in broad factual scenarios and overlaps with other aspects of the Convention is: what amounts to a fundamental breach, or, what renders a breach "fundamental" in terms of satisfying the test in Article 25? How the tests of Article 25 are applied to various situations arising under different aspects of the CISG will be explored below in reference to different Vis Moot scenarios and arguments, helping to illustrate the ambiguities and strengths of the fundamental breach provision.

(b) Fundamental breach due to non-conformity of goods - general issues

The ability for a buyer to avoid the contract due to delivery by the seller of nonconforming goods is an important feature of the CISG. However, in order to avoid the contract in such circumstances, the non-conformity of the goods must amount to a fundamental breach under Article 25. Various general rules in respect of common fact scenarios have been developed by the courts as guiding principles on instances in which the delivery of nonconforming goods may amount to a fundamental breach. Two basic rules have been established. The first is that delivery of non-conforming goods will not amount to a fundamental breach in circumstances where "the buyer, without unreasonable inconvenience can use the goods or resell them even at a discount" ${ }^{\prime 228}$. The second consequence of this principle is that the delivery of non-

\footnotetext{
${ }^{226}$ UNCITRAL Digest of Article 25 case law on the United Nations Convention on the International Sale of Goods provides a concise summary of some key 33 decisions on Article 25 , it is available at: http://www.cisg.law.pace.edu/cisg/text/digest-art-25.html (last updated on June 30, 2009).

${ }^{227}$ See both UNCITRAL Digest of Article 25 case law on the United Nations Convention on the International Sale of Goods, available at: http://www.cisg.law.pace.edu/cisg/text/digest-art-25.html (last updated on June 30, 2009); and Schlechtriem and Schwenzer, above n38, 293-297.

${ }^{228}$ UNCITRAL Digest of Article 25 case law on the United Nations Convention on the International Sale of Goods, para 7, available at: http://www.cisg.law.pace.edu/cisg/text/digest-art-25.html; Bundesgerichtshof 3 April 1996, Germany; Bundesgericht 28 October 1998, Switzerland.
} 
conforming goods that "cannot be used or resold with reasonable effort" 229 will amount to a fundamental breach even where the goods are still able to be used to some extent having suffered from an irreparable defect ${ }^{230}$. The criteria under Article 35(2) are relevant when assessing whether a breach is fundamental, Schlechtreim discussed this point ${ }^{231}$ :

\begin{abstract}
The criteria for implied agreements under Article 35(2), in particular features required to meet the 'fitness for a particular purpose', test under Article 35(2)(b), may also influence the weight of a non-conformity, e.g. where a machine, manufactured to the specifications of the buyer, does not function, but can also not be used otherwise, because no one would take it (not even as scrap because of the costs of transportation to a scrap yard).
\end{abstract}

The difficulty with the application of the above tests, and the scenario identified by Schlechtriem, are reflected in the eleventh Vis Moot. The facts of this problem, like most reallife factual scenarios, do not fit neatly within an identified category. Claimant and Respondent concluded a contract for sale of six Model 14 auger-feeder packaging machines (from here referred to as "machines" or "packaging machines"). Upon delivery, Claimant placed the machines into operation, using four to package salts as well as other products, and two remaining ones to package all products other than salt. Shortly after having been put into operation, the machines used for packaging salt corroded and were damaged beyond repair ${ }^{232}$. The dispute primarily concerned issues of conformity, namely whether the packaging machines delivered were in conformity with the contract and whether the contract required them to be capable of packaging corrosive goods (in particular, salt). There was no explicit reference to the requirement of the machines to package salt, or any other corrosive goods. It was alleged that salt was mentioned in a conversation between the parties following the conclusion of the contract. The contract explicitly called for the machines to be capable of packaging "a wide range of dry bulk commodities" 233 . Claimant argued that Respondent breached the contract in two ways - by delivering the machines that were not in conformity with the contract in general, and by

\footnotetext{
${ }^{229}$ UNCITRAL Digest of Article 25 case law on the United Nations Convention on the International Sale of Goods, para 7, available at: http://www.cisg.law.pace.edu/cisg/text/digest-art-25.html

${ }^{230}$ UNCITRAL Digest of Article 25 case law on the United Nations Convention on the International Sale of Goods, para 7, available at: http://www.cisg.law.pace.edu/cisg/text/digest-art-25.html; Cour de cassation 23 January 1996, France; Oberlandesgericht Frankfurt a.M. 18 January 1994, Germany; Landgericht Landshut 5 April 1995, Germany; Oberlandesgericht Innsbruck 1 July 1994, Austria.

${ }^{231}$ Schlechtriem and Schwenzer, above n38, 296.

${ }^{232}$ Eleventh Vis Moot Problem, Statement of Case, para 8.

${ }^{233}$ Eleventh Vis Moot Problem, Claimant Exhibit no. 1. See the discussion in Chapter 1 - Interpreting parties' intentions - Article 8 on the interpretation of the contract in this problem.
} 
delivering the machines that were not fit for a particular purpose of packaging salt. Claimant avoided the contract on the basis of fundamental breach. Of course this problem demonstrates the difficulty in applying Schlechtriem's example above to an imperfect set of facts, namely where the existence of the agreed particular purpose is itself in dispute. The machines that were delivered, at the time they were delivered, were still capable of packaging a "wide range of dry bulk commodities". They were not, however, capable of packaging corrosive commodities. Had they not been used to package corrosive commodities, they would not have deteriorated into a state beyond repair, where they can no longer be used or resold. In support of its arguments that it was substantially deprived of what it was entitled to expect under the contract, Claimant argued that its expectation was discernible from the contract ${ }^{234}$ and that Respondent could have derived from the contract and from the relevant surrounding circumstances that the machines will need to be suitable for packaging a wide range of products without restrictions ${ }^{235}$. Claimant followed the line of argument that, given the machines were not suitable for packaging salt at the time of delivery, and therefore not in conformity with the contract, the detriments arising out of this fact would have to be both, foreseeable to the buyer - in reference to the Article 8(2) test of a reasonable buyer in the same position and type of business - and were also likely to be substantial, as they eventually turned out to $\mathrm{be}^{236}$. Respondent argued, in terms of foreseeability, that it must be assessed as at the time of the conclusion of the contract ${ }^{237}$. Claimant, however, relied on the unsettled views in respect of the timing at which foreseeability is to be measured and argued that the subsequent circumstances, that is the telephone conversation between the parties during which salt was allegedly mentioned, must also be taken into account ${ }^{238}$. This problem demonstrates rather clearly various issues with the application of Article 25. Firstly, the difficulty in applying the fundamental breach tests to the issue of delivery of non-conforming goods where the lack of conformity is itself in dispute. Secondly, it opens up a new area for consideration - the cases which do not fit neatly into the general categories of goods either being used for other, or lesser purposes or where the goods are in such a state so as not to be useable or

\footnotetext{
${ }^{234}$ See Enderlein and Maskow, above n70, Art. 25, para 3.3: "the expectation of a party must have been discernible from the contract". Claimant's arguments are in: Univeristy of Heidelberg, Memorandum for Claimant, Eleventh Vis Moot, 23.

${ }^{235}$ Univeristy of Heidelberg, Memorandum for Claimant, Eleventh Vis Moot, 23.

${ }^{236}$ Ibid, 23-27.

${ }^{237}$ National University of Singapore, Memorandum for Respondent, Eleventh Vis Moot, 15.

${ }^{238}$ University of Heidelberg, Memorandum for Claimant, Eleventh Vis Moot, 27.
} 
resalable. This problem presents the issue of goods which, upon delivery, were in a good working condition and could have been used for various purposes, including those required under the contract, and which also could have been resold at that time. The desperate state of the goods only occurred due to the buyer's misguided misuse of those goods. There are also various questions of degree that this problem introduces. For example, at which point should the buyer have ceased using the machines for packaging a corrosive good that was clearly damaging them? Should this have occurred prior to these machines being rendered entirely inoperable? Is the breach indeed fundamental where the buyer still has two fully functioning machines it can continue to use or sell? Finally, the problem, through the participants' memoranda and arguments, demonstrated the difficulty in applying standards that have not been applied in a uniform way across the board, in particular the tests concerning the timing at which foreseeability is to be ascertained.

(c) Fundamental breach due to defective goods \& seller's right to cure - interplay between Articles 25, 49 and 48

A specific issue which arises in terms of assessing whether a breach is fundamental occurs in circumstances where the goods delivered are defective but can be repaired. Pursuant to Article 48, the seller has the right to cure in the event it fails to perform its obligations where such cure can be accomplished "without unreasonable delay and without causing the buyer unreasonable inconvenience". There are diverging opinions on the application of the fundamental breach provision in such situations. The CISG Advisory Council in its opinion stated that ${ }^{239}$ :

There is no fundamental breach where the non-conformity can be remedied either by the seller or the buyer without unreasonable inconvenience to the buyer or delay inconsistent with the weight accorded to the time of performance (emphasis added)

Most courts have been of the similar view, namely that the circumstances in which the seller may repair the goods easily, in a fast and efficient manner and "without any inconvenience to the

\footnotetext{
${ }^{239}$ CISG Advisory Council Opinion No. 5 "The buyer's right to avoid the contract in case of non-conforming goods or documents" 7 May 2005, Badenweiler (Germany). Rapporteur: Professor Dr. Ingeborg Schwenzer, LLM, Professor of Private Law, University of Basel, available at: http:/ www.cisgac.com/default.php?ipkCat $=128$ \&ifkCat $=147 \&$ sid $=147 \# 2$
} 
buyer", non-conformity will not amount to a fundamental breach ${ }^{240}$. Schlechtriem in the Commentary provides a more elaborate view on such situations ${ }^{241}$ :

\begin{abstract}
...there is initially no fundamental breach of contract in cases in which it can be expected of the seller to repair the gods, deliver substitutes, or remove a defect in title within a time which is reasonable and which takes account of the buyer's plans for the goods, and it is possible for the seller to do so......A mere offer from the seller to that effect cannot, however, prevent a breach of contract being fundamental...And the lapse of an additional period of time for cure also does not change ('upgrade') any non-conformity into a fundamental breach.
\end{abstract}

In the sixteenth Vis Moot there was no dispute as to the existence of non-conformity, but only as to whether the breach arising out of the delivery of non-conforming goods was fundamental, in light of the actual defects and the seller's offer of repair. The problem therefore addressed precisely this specific issue identified throughout the CISG community in recent years. Claimant and Respondent concluded a contract for the sale of one hundred "Tera" cars. Upon delivery to Claimant, the cars were driven from the port to the showroom and the storage area. The engines did not run properly and had severe misfiring which almost made the cars completely undriveable ${ }^{242}$. Claimant submitted that the delivery of the Tera cars in an unfit and undriveable state amounted to a fundamental breach of the contract by Respondent, and that such fundamental breach is not precluded by an offer to cure nor does it mitigate Claimant's right to avoid the contract ${ }^{243}$. The initial premise was that the delivery of cars which were close to "undriveable" due to a failure of the 'engine control unit' rendered them unfit both for ordinary use, and for resale. As such Claimant argued it was substantially deprived of its expectation under the contract ${ }^{244}$. Moreover, Claimant argued that both subjectively Respondent, and objectively a reasonable person in the same type of business, would have foreseen that a delivery of "defective cars would deprive Claimant of his expectation of resale and profits" 245 . Arguing, and proving, fundamental breach where the breach itself is not in dispute is significantly easier than where it is. This problem, therefore, centred on the question of what impact the seller's offer

\footnotetext{
${ }^{240}$ Handelsgericht des Kantons Zürich 26 April 1995, Switzerland; Cour d'appel, Grenoble 26 April 1995, France; Oberlandesgericht Koblenz 31 January 1997, Germany.

${ }^{241}$ Schlechtriem and Schwenzer, above $\mathrm{n38}, 295$. This view is also expressed in Oberlandesgericht Koblenz, 31 January 1997, Germany.

242 Sixteenth Vis Moot, Statement of Case, para 11, 5 .

${ }^{243}$ University of Sydney School of Law, Memorandum for Claimant, Sixteenth Vis Moot, 3.

${ }^{244}$ Ibid, 28 .

${ }^{245}$ Ibid, 30.
} 
to repair the defect had on the fundamentality of the breach ${ }^{246}$. The offer of repair was subject to considerable discussion between the parties as to the timeframes within which the cars will be repaired. The seller expressed its confidence that the repairs would be carried out within a week or ten days from the day of the parties' conversation. However, he could not provide any guarantees as to the actual timeframe required for the repair of all of the cars for the minimum of three subsequent days, or possibly an even longer period, since its actual estimation of the time required for repair was entirely subject to its staff first travelling to Claimant's country, examining the cars on site, establishing for certain what the defect was and successfully repairing the first $\operatorname{car}^{247}$. Claimant therefore argued that the lack of a guarantee from the seller as to the actual period of time it would take for the repairs to be completed caused it significant uncertainty, such uncertainty making it face the likelihood of loss of potential sales, customers and profit ${ }^{248}$. Respondent relied on the general principles of the CISG, namely that the contract preservation is preferred over contract avoidance and that prevention of a "particularly severe" remedy of contract avoidance should be prevented wherever possible ${ }^{249}$. Respondent argued that the fundamental breach is precluded by its offer to repair the cars, since it "would have made the cars ready for resale without unreasonable delay or inconvenience" ${ }^{250}$. It relied on the seller's right to cure contained in Article 48 and Lookofsky's opinion that "even serious defects should not be regarded as fundamental when a seller invokes its right to cure under Article $48^{, 251}$, and that once such an offer is made the buyer is obliged to accept it "unless he can prove that there are delays and inconveniences associated with the proposed cure that are unreasonable" ${ }^{252}$. Respondent was thus left to show that its offer did not constitue an unreasonable delay. It argued that the arrival of its personnel in Claimant's country within three days in order to inspect and (hopefully) repair the cars was in no way an unreasonable delay, and that no "unreasonable inconvenience" could have been caused because Claimant was not

\footnotetext{
${ }^{246}$ The offer to repair the good was in fact made by the manufacturer via the seller which in itself raised several issues in this problem. However, since this question is not relevant for the discussion of the particular point in this chapter, the author will only refer to "the seller" so as not to distract the reader from the essential point discussed.

${ }^{247}$ See Sixteenth Vis Moot Problem, Statement of Case.

${ }^{248}$ University of Sydney School of Law, Memorandum for Claimant, Sixteenth Vis Moot, 30.

${ }^{249}$ Stockholms Universitet, Memorandum for Respondent, Sixteenth Vis Moot, 25.

${ }^{250}$ Ibid, 25.

${ }^{251}$ Joseph Lookofsky, above n210, 121.

${ }^{252}$ Stockholms Universitet, Memorandum for Respondent, above $\mathrm{n} 247,25$; in reliance on Schwenzer in Schlechtriem and Schwenzer, above n38, 565-567.
} 
required to take any action itself ${ }^{253}$. It then turned to the interpretation of the actual contract between the parties in an attempt to assert what importance was placed on the timing of delivery. It concluded that, since the contract allowed for shipment "as space is available", time was clearly not of the essence, and therefore the delays required for the repair of the cars could not have been unreasonable in the circumstances ${ }^{254}$. It concluded that, given the cars were eventually repaired within five working days, delays could not have been deemed unreasonable. It relied on the CISG Advisory Opinion no. 5 discussed above and the decisions which uphold the similar view that defects which can be easily remedied by the seller do not amount to a fundamental breach of contract, and therefore avoidance is not an available remedy to the buyer $^{255}$. The parties in this fact scenario relied on all the available opinions as to the impact an offer to cure has on the fundamentality of the breach. The ultimate question becomes one of fact and degree. The essential issue this problem sought to resolve is: what constitutes an unreasonable delay or inconvenience? And on that basis, did the present circumstances justify the buyer's avoidance in terms of such delay and/or inconvenience? Should the element of uncertainty, which was at the crux of the buyer's "inconvenience", be relevant in assessing whether the buyer was justified in refusing the offer to cure? These questions are only raised, although not resolved by this problem. Schlechtriem's reasoning that the offer to cure does in no way "upgrade" or "downgrade" a fundamental breach is interesting in this context. Perhaps a different way to approach this problem is by suggesting that for an offer to cure to apply in a situation of a fundamental breach, it will involve an "option" to cure offered to the buyer. Such an option is to be taken up or refused at the buyer's discretion, given the buyer is the party severely inconvenienced by the fundamental breach and as such should be the party in the position to ascertain whether the seller's offer truly is "without any inconvenience to the buyer". Where the offer genuinely doesn't cause any inconvenience to the buyer, any reasonable buyer would not have a motive to refuse it. Therefore, and following this line of reasoning, whether an offer to cure is made or not should in no way affect the existence of a fundamental breach, but may be a way to mitigate it in certain circumstances. Whether this interpretation is in fact the one that should be applied is not entirely clear. Such interpretation may go against the general principles of the CISG, namely the preference for contract continuation over avoidance wherever

\footnotetext{
${ }^{253}$ Stockholms Universitet, Memorandum for Respondent, above n247, 25.

${ }^{254}$ Ibid.

255 Ibid.
} 
possible ${ }^{256}$. The rules around offer to cure are therefore still somewhat unsettled, as illustrated in the above example, and would benefit from further academic and judicial guidance in the coming years. In particular, more guidance could be provided on the question of whether, and to what degree, certainty is required as to the timeframes with in which the seller offers to cure a defect.

(d) Fundamental beach as a result of non-delivery, delays in, or partial delivery of goods

Whether a breach resulting from non-delivery, partial delivery or a delayed delivery amounts to a fundamental breach is another issue that has caused widespread debate among the CISG experts. As a starting rule, it has been held that the final non-delivery of goods by the seller amounts to a fundamental breach, although this will not be the case where the seller has a justifiable reason for such non-delivery ${ }^{257}$. However, in cases of partial delivery, for example where goods are to be delivered in instalments and one of such instalments is not delivered, as a rule of thumb such non-performance will not amount to a fundamental breach, although it will be a breach of contract nonetheless ${ }^{258}$. Likewise, as a general rule late delivery will not in itself constitute a fundamental breach, unless the time for delivery is of the essence ${ }^{259}$. Whether the time is of the essence is to be determined either through the explicit terms of the contract, or impliedly from "evident" circumstances ${ }^{260}$. Where a party makes a "final and unjustified" announcement that it will not fulfil its contractual obligations, such an announcement is generally held to constitute a fundamental breach ${ }^{261}$.

The issues of partial and late delivery is particularly interesting, as it tends to arise in cases where a force majeure event has lead to an impediment making it difficult, if not impossible, for the seller to make full delivery, on time, as required under the contract. The

\footnotetext{
${ }^{256}$ Franco Ferrari, above n210, 501; Joseph Lookofsky, above n210, 122.

${ }^{257}$ Pretura circondariale de Parma 24 November 1989, Italy; Oberlandesgericht Celle 24 May 1995; Germany.

${ }^{258}$ Oberlandesgericht Düsseldorf 24 April 1997, Germany.

${ }^{259}$ Corte di Appello di Milano 20 March 1998, Italy; Oberlandesgericht Düsseldorf 24 April 1997 Germany; ICC International Court of Arbitration, Award 7585 of 1992.

${ }^{260}$ Oberlandesgericht Hamburg 28 February 1997, Germany; Corte di Appello di Milano 20 March 1998, Italy; ICC International Court of Arbitration, Award 8786 of January 1997.

${ }^{261}$ Oberlandesgericht Celle 24 May 1995, Germany; Oberlandesgericht München 15 September 2004, Germany; Tribunal of International Commercial Arbitration at the Russian Federation Chamber of Commerce, Award $387 / 1995$ of 4 April 1997, Russia.
} 
interest in such cases concerns the remedies that will be available to the buyer in the circumstances. Where an Article 79 impediment is found to exist, it will preclude the buyer's right to claim damages. However, where a partial, and potentially also late delivery is made, the question emerges whether the buyer will be stripped of its ability to avoid the contract, or whether such partial or late delivery can amount to a fundamental breach. In general whether such breach is fundamental will be a question of degree. Both the seventh and the twelfth Vis Moots involved such scenarios.

The seventh Vis Moot concerned an issue of partial delivery. An export prohibition due to flooding prevented Respondent from making a full delivery. Since the contract called for "no partial delivery", Respondent sought to amend the contract on various occasions so as to extend the letter of credit, given the circumstances. Such an amendment was not agreed and Respondent wrote to Claimant informing it that it will not be supplying it with the goods due to failure to agree the amendment. Respondent argued that a partial delivery would not have constituted a fundamental breach of the contract ${ }^{262}$. Respondent relied on the high threshold that must be reached for a fundamental breach to be established, and argued that in the present case, Claimant would have used the goods delivered "regardless of the amount delivered in the first shipment" ${ }^{263}$. The essential premise of the argument was that a partial delivery of goods which Claimant could have used could not satisfy the high threshold test of a fundamental breach. On the other hand, Claimant argued that Respondent's "final and unjustified" announcement that it will not deliver the goods as required under the contract constituted a fundamental breach. This problem therefore applied the general principles of rules that have developed over the years in relation to particular instances that amount to fundamental breach. The twelfth Vis Moot, however, took considerations to a slightly higher level. The twelfth Vis Moot concerned a factual scenario involving both a delayed and partial delivery. A storm hit the cocoa producing area in Respondent's country, leading to an export ban. These events precluded Respondent from honouring its obligations under the contract to deliver a certain amount of cocoa within specified timeframes. Respondent informed Claimant of the delays involved resulting from these events, and the parties maintained ongoing correspondence during the waiting period. Respondent managed to make a partial delivery, which Claimant accepted. However, the remainder of the

\footnotetext{
${ }^{262}$ University of Heidelberg, Memorandum for Respondent, Seventh Vis Moot, IV, A, 1(a).

${ }^{263}$ Ibid.
} 
delivery was four and a half months late ${ }^{264}$. Within these facts, the parties could explore the thresholds of the fundamentality of a breach. On the one hand, Claimant argued that various breaches occurred - Respondent failed to deliver within the specified timeframe, it failed to deliver within the additional timeframe and that such breaches, irrespective of partial delivery, amounted to a fundamental breach. It argued that such a breach was foreseeable to Respondent on the basis of their communications throughout the waiting period, in particular as Claimant grew impatient and stressed the importance of a timely delivery ${ }^{265}$. Both parties relied on the decision in Foliopack v. Daniplast ${ }^{266}$. Claimant relied on this decision by drawing out the analogy of a particularly late and partial delivery which amounted to a fundamental breach, while Respondent relied on it in stating that, while non-delivery constitutes a fundamental breach....late delivery as such does not ${ }^{267}$. This is a very good demonstration of the difficulties arising from application of the fundamental breach test. The test whether a breach is fundamental is necessarily one of fact and degree. Thus, applying analogous fact scenarios is only useful to a certain extent; determinations must be made on the specific facts of each case. Conducting an assessment of whether a breach is fundamental must be done in reference to all relevant circumstances and terms of the contract, interpreted in a conceptual, rather than overly technical manner.

(e) Legal analysis

Fundamental breach as a precondition of contract avoidance is a reasonably settled area of the CISG. There is a comprehensive amount of scholarly commentary and reported decisions available to aid in its interpretation. The difficulty with assessing whether a breach is fundamental arises primarily out of the nature of this exercise - that is, one of fact. Relying on decisions which were based on similar, although not identical, fact scenarios has the risk of proving inadequate and possibly vague. Nonetheless, general categories of common factual

\footnotetext{
${ }^{264}$ Twelfth Vis Moot Problem, for a factual summary please refer to Appendix 1 .

${ }^{265}$ University of Copenhagen, Memorandum for Claimant, Twelfth Vis Moot, 8.

${ }^{266}$ Foliopack v. Daniplast, Pretura Circodariale di Fidenza, Italy, 24 November 1989.

${ }^{267}$ Humboldt Universität zu Berlin, Memorandum for Respondent, Twelfth Vis Moot, 17.
} 
scenarios have been reasonably well established through reported decisions and are a convenient starting point for any factual determination.

5 Exemptions - Article 79 "Force Majeure"

(a) Introduction

Inability to perform the contract due to circumstances outside of one's control is, not surprisingly, a common issue in both domestic and international sale of goods contracts. There is a variety of labels that are used in domestic laws for this doctrine such as "impossibility, Act of God, frustration, force majeure, failure of presupposed conditions"268. Article 79 exempts the promisor, or a third person engaged by the promisor to perform all or a part of the relevant contract, from the liability to pay damages where the elements of article 79(1) are satisfied. These elements are the existence of an impediment beyond the promisor's control; that such an impediment was not reasonably foreseeable at the time of the conclusion of the contract; and that it was, or its consequences were, unavoidable. Article 79 confines the exemption to a party's right to claim damages, and leaves any other right under the CISG open. Article 79(3) provides that the exemption will have the effect "for the period during which the impediment exists", and article 79(4) requires the party who fails to perform to give the other party notice of such inability, to be received "within a reasonable time". Honnold suggests that it is not practical to enumerate all the circumstances that excuse a failure to perform, and as such: ${ }^{269}$

\footnotetext{
Instead, words must try to express a dividing point on a continuum between "difficult" and "impossible". Even domestic rules cast in terms of "impossibility" conceal questions of degree...the [CISG] stands somewhere between the most strict and the most liberal of the domestic systems."
}

According to Stoll and Gruber, the exemption in article 79 will, however, come into consideration only in very narrow conditions ${ }^{270}$. This view is supported by the conclusions of

\footnotetext{
${ }^{268}$ Honnold, above n39, 472 .

${ }^{269}$ Honnold, above $n 39,483$.

${ }^{270}$ Stoll and Gruber in Schlechtriem and Schwenzer, above n38, 807.
} 
the CISG Advisory Council in its opinion on article 79, namely that the exemption in article 79 has been invoked in litigation and arbitration to-date "with limited success" 271 . The lack of trends to be drawn out of the reported decisions, as discussed by the CISG Advisory Council in its opinion may reinforce the view that uniform interpretation of article 79 is still in the making. In 1999 Honnold concluded that ${ }^{272}$ :

\begin{abstract}
In spite of strenuous efforts of legislators and scholars we face the likelihood that Article 79 may be the [CISG's] least successful part of the half-century of work towards international uniformity... Those who are not able to solve the problem by contract must await the process of mutual criticism and adjustment by tribunals and scholars in the various jurisdictions.
\end{abstract}

Despite the increase in academic writing on article 79, as well as the increased amount of reported decisions involving article 79 issues, the "process of mutual criticism and adjustment by tribunals and scholars" discussed by Honnold still continues ten years on. The article 79 chapter of the second English edition of the Schlechtriem/Schwenzer Commentary has been rewritten to a large extent and, aside from its different structure, contains much additional content compared to its parallel chapter in the first edition. The CISG Advisory Council's opinion identifies key areas of controversy in applying article 79 , namely delivery of non-conforming goods, failure to perform due to third persons (application of article 79(2)), and the issue of "hardship". The second English edition of the Schlechtriem/Schwenzer Commentary raises another key issue, namely the contrast between the unique CISG mechanisms which takes the claim to damages as its starting point rather than the claim to performance in the exemption provision as is the case with most domestic laws ${ }^{273}$. The CISG premise that the contract should be kept alive, and that avoidance of the contract should be the last resort for the parties is possibly relevant to this formulation of article 79. However, as pointed out by Stoll and Gruber ${ }^{274}$ :

It seems reasonable to assume that the right to performance is lost or at least no longer enforceable when a legal or factual impediment to performance exists,

\footnotetext{
${ }^{271}$ CISG-AC Opinion No. 7 "Exemption of Liability for Damages under Article 79 of the CISG", Rapporteur: Professor Alejandro M. Garro, Columbia University School of Law, New York, N.Y., USA, para 2, available at: http://www.cisg.law.pace.edu/cisg/CISG-AC-op7.html

${ }^{272}$ Honnold, above n39, 483-484.

${ }^{273}$ Stoll and Gruber in Schlechtriem and Schwenzer, above n38, 808.

${ }^{274}$ Ibid.
} 
because the promisor's primary interest in exoneration form his obligation to perform is satisfied.

These issues with the interpretation of article 79 are reflected in the sixteen years of the Vis Moot. Article 79 problems have featured prominently throughout the years of the competition, on a par only with article 35 . Article 79 was an issue at regular intervals, namely in the first, sixth, seventh and twelfth problems. The seventeenth Vis Moot which is due to be discussed next year also features an article 79 issue. The factual frameworks of the problems are broad and diverse raising multiple article 79 issues. The first problem concerned a factory fire destroying most of the rather unique goods; the sixth a plane crash, leaving no survivors, where the plane was carrying staff of the seller's contractor bound to complete performance of the contract at buyer's premises; the seventh involved floods in the wheat producing areas of the seller's country leading to export bans imposed by the seller's government; the twelfth problem, similarly to the seventh, involved a storm hitting the cocoa producing area in the seller's country leading to export bans by the seller's government, and the seventeenth (the current) problem contains a sophisticated factual matrix involving several events affecting performance such as a shipping accident, riots in the buyer's country and a military takeover. All of these problems have concerned those key issues of uniform application raised in scholarly writing, the CISG Advisory Council opinion discussed above, and illustrated through the reported decisions. They are further discussed in the context of key issue below.

(b) Elements of Article 79 - Foreseeability and Ability to overcome the impediement

The main element that needs to be satisfied when applying the test in Article 79(1) is foreseeability - namely whether the impediment was foreseeable. A body of opinion exists which holds that where an impediment lies within the supplier's sphere of risk, an exemption under Article 79(1) will not apply ${ }^{275}$. The second and consequential element concerns the ability by the party in breach to avoid and overcome the impediment.

\footnotetext{
${ }^{275}$ Tribunal of International Commercial Arbitration at the Russian Federation Chamber of Commerce and Industry, Arbitration proceeding 155/1994 (Metallic sodium case), 16 March 1995, Russia; Schiedsgericht der Handelskammer Hamburg, 21 March 1996, Germany; FCF v Adriafil, Bundesgericht, Switzerland, 15 September 2000 .
} 
In general the promisor is responsible for those circumstances that lie within its own sphere of risk, such as "personal inadequacy or momentary failings ${ }^{276}$. The broad responsibilities identified as existing within the promisor's sphere of risk include "impediments attributable to the nature and organisation of his sphere of control" 277 and "the correct organisation and trouble-free passage of the steps necessary to prepare for and perform the contract" ${ }^{278}$. An arbitration case in 1998 also established that the promisor will be responsible for providing adequate storage facilities for the goods ${ }^{279}$.

The very first Vis Moot concerned an Article 79 issue, and was a classic example on the questions of the sphere of risk. Claimant and Respondent entered into a contract for the sale of computer chips to Claimant. Respondent kept the first lot of manufactured new chips in its warehouse awaiting shipment. While the goods where still in the warehouse a fire broke out and damaged most of the computer chips. The fire also resulted in damage to Respondent's factory, causing delays to its continuation of production. The fire department issued a report which found that the cause of fire was not something for which Respondent could be blamed. However, an interesting aspect to the facts was that Respondent was in the process of installing a new fire alarm and sprinkler system, and installation not having been complete, both the old and the new systems were turned off at the time the fire broke out. It was found that, had either of these been active, the fire probably could have been prevented ${ }^{280}$. This is an excellent example of the issues concerning the promisor's sphere of risk - the fact that Respondent was installing a new fire alarm system may go some way in showing it was proactively seeking to minimise risks that may occur to the storage facilities. However, it is likely that Respondent will not be excused under Article 79 given it could have prevented the damage by activating the old fire alarm. The fact that Respondent knew that the goods were being stored in the warehouse should have sufficiently alarmed it to ensure they were stored safely. However, it was not only Respondent's storage facilities, but also its factory, which suffered damage. The facts are not sufficiently detailed o this point, but it would be interesting to ascertain whether there was any manner in which Respondent could have ensured a fire alarm was in place while the new system was being

\footnotetext{
${ }^{276}$ Stoll and Gruber in Schlechtriem, above n38, 815 .

${ }^{277}$ Ibid.

278 Ibid.

${ }^{279}$ Ibid., Bulgarian CCI Ct Arb, 12 February 1998.

${ }^{280}$ First Vis Moot Problem.
} 
installed. Unfortunately, memoranda are not available from this year of the competition. It is worthwhile noting, however, that this problem was presented in 1993, five years prior to the Bulgarian arbitral decision requiring the promisor to procure adequate storage facilities ${ }^{281}$.

In the twelfth Vis Moot Claimant argued that the storm which hit Respondent's country and impacted the cocoa plants could reasonably have been foreseen by Respondent, because Respondent was "expected to take weather conditions such as storms into account at the time of contracting"282. Claimant argued that a common fact is that weather impacts harvests of crops such as cocoa beans, and that various weather factors can have devastating impacts on agricultural products, such as storms, heavy rain or drought. Respondent is very experienced in the business of dealing cocoa and, arguably, could not have been unaware of the potential impacts of weather. Claimant argued that Respondent accepted all risks associated with weather conditions that could impact its cocoa beans when it entered into the contract for the sale of cocoa. On this premise Claimant argued that weather conditions impacting the agricultural crops were within Respondent's sphere of risk ${ }^{283}$. Interestingly, the facts are framed in such a way that both parties argued opposite points in reliance on the same fact. According to the Twelfth Vis Moot problem, once on a previous occasion, some twenty years prior to the time of the dispute, another storm hit the cocoa plantation in Respondent's country damaging the crop, although not as severely as the one in the dispute at hand ${ }^{284}$. As may be guessed, Respondent relied on its fact to demonstrate that storms which have a devastating impact on its cocoa plants are such a rare occurrence, that in its forty years in operation it has only experienced one similar event, although of a lesser impact. Claimant, on the other hand, would use this to demonstrate that that one prior storm is sufficient to alert Respondent to the possibility of such events occurring and having a substantial impact on its crop and its business. On that basis, Claimant would argue, Respondent undertook that risk when entering into the contract. In terms of Article 79, Claimant would argue that this was therefore foreseeable and within the Respondent's sphere of risk. Claimant argued that Schlechtriem's commentary to the Vine Wax case supports the view that ${ }^{285}$ :

\footnotetext{
${ }_{281}^{281}$ Bulgarian CCI Ct Arb, 12 February 1998.

${ }^{282}$ University of Copenhagen, Memorandum for Claimant, Twelfth Vis Moot, 21.

${ }^{283}$ University of Copenhagen, Memorandum for Claimant, Twelfth Vis Moot, 22.

${ }^{284}$ Twlefth Vis Moot, Procedural Order No2, question 8).

${ }^{285}$ University of Copenhagen, Memorandum for Claimant, Twelfth Vis Moot, 22.
} 
Respondent chose to enter into this business and thereby accepted that delivery problems might occur. If the Respondent could not bear the risk, or did not want to, it should have contractually limited it or excluded it

According to Claimant, therefore, Respondent took on all risks related to "its sphere of application", which in this case includes storms. If it wanted to prevent consequences of hardship, it should have included a specific clause in the contract which would have limited its liability in strenuous circumstances ${ }^{286}$. Whether "hardship" as a category may be caught by the definition of "impediment" in Article 79 is not an entirely settled question although general opinion indicates that it may apply to a certain extent. Hardship may be considered to arise where unforseeable circumstances outside of one's control render performance excessively onerous $^{287}$.

The language of Article 79 does not expressly equate the term "impediment" with an event that makes performance absolutely impossible. Therefore, a party that finds itself in a situation of hardship may invoke hardship as an exemption from liability under Article 79... In a situation of hardship under Article 79, the court or arbitral tribunal may provide further relief consistent with the CISG and the general principles on which it is based. ${ }^{288}$

Claimant's interpretation in this instance may seem overly onerous on Respondent. However, placing such risk on Respondent and an expectation that events which are not entirely improbable are within its sphere of risk, is not a surprising outcome given the fact that most courts are reluctant to bring a party under the Article 79 exemption.

(c) Temporary \& Partial Impediments

Where the seller has suffered an impediment which causes it to be unable to deliver the full amount contracted for, but instead, only deliver a part of the goods, the buyer may resort to remedies for breach contained in Articles 46-50 in respect of that part of the goods which is

\footnotetext{
${ }^{286}$ Ibid.

${ }^{287}$ Ibid.

${ }^{288} \mathrm{Ibid}$; Other authors have recommended including a specific force majeure clause in international sales contracts, see: Bianca and Bonnell, above $\mathrm{n} 75,576$; Joseph Lookofsky Understanding the CISG in Europe, ( ${ }^{\text {nd }}$ ed), (Kluwer Law International, 2004), 128; Jennifer Bund "Force majeure Clauses: Drafting Advice for the CISG" J L \& Com (1998), 381-413,391.
} 
missing ${ }^{289}$. Where a party fails to perform due to an impediment as envisaged under Article $79(1)$, it is required under Article 79(4) to provide a "timely notice" to the other party of that impediment and the effect of the impediment on that party's ability to perform the contract. Article 79(3) limits the duration of the exemption to the period of time during which the relevant impediment subsists. ${ }^{290}$ In considering the application of Article 79 to temporary impediments Honnold considered an example where the seller was contracted to deliver goods to the buyer by a particular date (in the example June 1), however due to an impediment (a government embargo "or a similar impediment" as used in the example) prevented the delivery by that date. The embargo resulted in one month's delay of the delivery ${ }^{291}$. Honnold examines this example by concluding that Article 79, although excusing the seller from delivering for the duration of the impediment and exonerating it from liability to pay damages, does not preclude the buyer from avoiding the contract - of course only where the delay constitutes a fundamental breach under Article $25^{292}$. The idea behind the operation of Article 79 is that, since the test for avoidance under the CISG is reasonably strict, Article 79 should not preclude the party from avoiding the contract despite an impediment as envisaged by Article 79 being the cause of the breach.

The twelfth Vis Moot contained a similar example to that discussed by Honnold. In its Memorandum Respondent argued that "If the parties contract for a certain good originating from a single country where an export restriction is imposed after the conclusion of the contract, the situation is a text book definition of an excuse under Art 79(1) CISG,293. Interestingly enough, however, problems involving "text book definitions" of Article 79 issues still contain sufficient factual ambiguity to call for extensive and robust arguments for both sides. A so called "text book" definition does not appear to automatically merit a "text book response". Quite the contrary, as discussed above, the decisions reported to-date appear to indicate that application of Article 79 is strict and rare. As such, the threshold for an exemption under this provision is arguably very high. The rarity and strictness with which the test is applied is demonstrated by Claimant's arguments in the twelfth Vis Moot, where it contended that "it is a strict and close to

\footnotetext{
${ }^{289}$ Honnold, above n39, 491 .

290 Ibid.

${ }^{291}$ Honnold, above n39, 490.

${ }^{292}$ Ibid.

${ }^{293}$ Humboldt-Universität zu Berlin, Memorandum for Respondent, Twelfth Vis Moot, 11.
} 
objective standard for excusing the promisor" and in so arguing it relied on several decisions $\mathrm{s}^{294}$ confirmed by scholarly opinion ${ }^{295}$ that "both national courts and arbitral tribunals adopt a rather restrictive attitude towards permitting any exemptions under Article 79"296. This strict application has resulted in the view that the parties should include specific clauses in their contracts limiting their risks, thus ensuring that they have a more robust protection should unforeseeable circumstances occur ${ }^{297}$, as mentioned in the preceding section.

(d) Non conforming goods

Exemption under article 79 for delivery by the seller of non conforming goods is generally viewed as a rare occurrence and a very narrow category ${ }^{298}$. An example used by the CISG Advisory Council in its opinion on Article 79 is that of a seller required to deliver frozen goods which arrive decomposed due to a power failure occurring after the seller has dispatched them, but prior to risk passing to the buyer ${ }^{299}$. Relying on Article 79 in such a scenario would require the usual Article 79 tests to be applied. The seller will bear the burden of proof and satisfy the elements of Article 79(1), namely that the power failure was beyond his control, that it was not foreseeable and that he was not able to avoid it. This issue was not raised in the Vis Moot problems, which is in accordance with its rare occurrence in general.

\footnotetext{
294 Tribunale Civile di Monza 14 January 1993. (Nuova Fucinati S.p.A. v. Fondmetal International A.B.), Italy; ICC Arbitration Case No. 6281 of 1989.

${ }^{295}$ Petar Šarčević and Paul Volken (ed) The International Sale of Goods Revisited (Kluwer Law International, 2001), 32.

${ }^{296}$ University of Copenhagen, Memorandum for the Claimant, Twelfth Vis Moot, 21.

${ }^{297}$ Ibid, 22. The Memorandum for Claimant relies on Schlechtriem's commentary on the Vine Wax case, Schlechtriem, Comment on BGH of 24 March 1999, JZ 1999, 794, 795 sub 1. d).

${ }^{298}$ CISG-AC Opinion No. 7 "Exemption of Liability for Damages under Article 79 of the CISG", Rapporteur: Professor Alejandro M. Garro, Columbia University School of Law, New York, N.Y., USA, available at: http://www.cisg.law.pace.edu/cisg/CISG-AC-op7.html. At para 8: "Cases in which a seller may be exempted of liability for delivering non-conforming goods are extremely rare. For example, goods that are unique and the subject of the contract may have already perished at the time of the conclusion of the contract and before the risk of loss passed to the buyer. In this exceptional case, Article 79 may apply as long as the seller had no knowledge of the prior destruction and could not reasonably have been expected to take the destruction of the goods into account at the time of the conclusion of the contract." The cases which have discussed this point are: Bundesgerichtshof, Civil Panel VIII, Germany, 24 March 1999, CLOUT Case No.271, (also referred to as the "Vine wax case"); and Bundesgerichtshof, Germany, 9 January 2002 (hereinafter the "Powder milk case").

${ }^{299}$ Ibid, para 12.
} 


\section{(e) Legal analysis}

As illustrated above, interpretation and application of article 79 is still a contentious matter. The view that the inclusion of a specific force majeure clause in contract is recommended in order to provide more robust protections to the parties and minimise the potential uncertainty with interpretation and limited application of article 79 has been expressed by authors. ${ }^{300}$ This recommendation confirms the view that, while article 79 provides some comfort to the parties in "force majeure" type events, it's application remains limited and to a degree uncertain. It is therefore prudent for the parties to include a robust force majeure clause catering for their circumstances in addition to reliance on article 79.

The exemption in Article 79 is extremely limited in its practicality, only excusing the defaulting party from paying damages, with particularly high thresholds that are seldom attained. As such it appears to provide little comfort and protection to those who have suffered from "unforeseeable impediments beyond their control". Nonetheless, the importance it plays should not be underestimated, and the amount of Vis Moot problems that have raised it, and continue to raise it in the case of the current Vis Moot problem, testifies to this fact. This is certainly an area that requires, and is likely to receive, more attention from the leading authorities on the CISG in the coming years.

\section{CONCLUSION}

A Promoting Uniformity \& Article 7(1)

It has been widely recognised by scholars and practitioners worldwide that a convention on international sales is only the beginning step in striving towards true uniformity of

\footnotetext{
${ }^{300}$ Stoll in Schlechtriem, above $\mathrm{n37}, 624$; Schlechtriem in the commentary to the Vine Wax case, BGH, Germany, 24 March 1999, section 1d.
} 
international trade law. Uniform application of the convention worldwide is equally important, or as quite eloquently stated by Ferrari ${ }^{301}$ :

In order to achieve uniformity in international trade law, however, it is not sufficient to enact uniform law conventions... It is equally important that its provisions... be interpreted the same way in various countries...

Promoting a uniform application may seem difficult given the lack of an overarching, central and international CISG court. Various authors have expressed doubt over the achievement of true uniformity of application of CISG provisions worldwide, as well as concern that obstacles on the path to uniformity such as homeward trends may hinder the approach of this ultimate goal. In the early years of the Convention, Honnold has captured similar concern in the context of seeking interpretive solutions for gap-filling ${ }^{302}$ :

\begin{abstract}
Admittedly, it would be wrong to give weight to domestic legal rules on points where the words of the Convention (in their full legislative context) speak with sufficient clarity to dislodge the natural predilection for familiar domestic law. However, this writer...confesses to despair over the power of words to communicate answers to the questions of degree that are intrinsic to our current problem. In this situation we need all the help we can get!
\end{abstract}

Nonetheless, a widely held and prevailing view among the CISG scholars and throughout reported CISG decisions is that the CISG should be applied autonomously, in its own right ${ }^{303}$. Bridge has argued that the drawbacks of uniform substantive law are possibly greater than may be appreciated, and that the value in application of domestic laws lies in its experience and highly developed and predictable principles ${ }^{304}$. It follows that uniform law, especially "young" documents such as the CISG, are unpredictable due to their novelty and only afford "second-

\footnotetext{
${ }^{301}$ Franco Ferrari "Uniform Application and Interest Rates under the 1980 Vienna Sales Convention" 24 GA J Int"1 \& Comp Law, 467.

${ }^{302}$ Honnold, above 39,480 .

${ }^{303}$ This view is widely held, in particular it has been reiterated by Schlechtriem in Schlechtriem and Schwenzer, above n38, 96; Bonell in Bianca and Bonell, above n75, Art 7, para 2.2.2; and numerous reported decisions, including MCC-Marble Ceramic Center v. Ceramica Nuova Dágostino 144 F.3d 1384 (11 th Cir. 1998);

Medical Marketing v Internazionale Medico Scientifica. S.r.l. No. Civ. A. 99-0380, 1999 WL 311945 (E.D. La. May 17, 1999); Richteramt Laufen des Kantons Berne, 7 May 1993.

${ }^{304}$ Michael Bridge The International Sale of Goods Law and Practice (2nd ed) (Oxford University Press, Oxford/New York, 2007), 507, Bridge comments: "Uniform substantive law is seen by some as superior to uniform choice of law, as constituting the next step on the road to a world legal order of private law that will eliminate barriers to trade posed by national legal difference. It comes, nevertheless, at a price. Contracting parties often choose certain countries' laws to govern their contracts because those laws are grounded in and are sympathetic to a broad experience of commercial matters, and have accumulated a body of principles worked out to a degree of predictability affording a measure of certainty to those who subject their dealings to them."
} 
best" solutions ${ }^{305}$. Bridge has precisely commented that the uniform application may not be achieved in the absence of a central "judicial machinery" which will provide uniform interpretation, and that the threat of homeward trends would therefore greatly jeopardise any success of uniform interpretation ${ }^{306}$ :

The CISG is less burdensome to master, however, than the several laws that have to be borne in mind by merchants trading on a diverse geographical plane. Unless it comes with the judicial machinery that aids the process of uniform interpretation in regional organizations like the European Union, however, uniform law like the CISG is threatened from its inception by the centrifugal forces that lead to national courts absorbing international instruments into the fabric of their national legal culture. This is particularly dangerous where a body of uniform special law, like sale, has no body of uniform general contract law on which to drop anchor. The widespread adoption of the CISG is only the beginning.

Whether these concerns reflect the actual state of CISG application is highly questionable. The modern international and commercial reality requires a unique framework which will evolve and adapt alongside the changes facing international trade. Stepping away from (archaic) domestic doctrines and adopting a modern document which takes into account the current global context $\mathrm{t}^{307}$, is a preferable approach, and one embraced by the CISG. Certain CISG jurists, such as Nottage, offer arguments contrary to those set out by Bridge above $\mathrm{e}^{308}$ :

The CISG offers a logical, coherent and comprehensive framework for working through quite complex legal issues that can develop in negotiating and implementing cross-border sales. One key advantage is therefore the accessibility of the Convention... The layout of the CISG is also logical, generally tracking the issues as they arise in actual commercial transactions...If the dispute does come before a court, and especially if it comes before an arbitral tribunal, CISG offers much more chance of consistency in interpretation... Familiarity with its rules can provide more meaningful and generalisable checklists and guidance on matters to be addressed and negotiated when planning cross-border deals

Zeller has considered in detail the degree of unification that has been achieved through the application of the CISG. Zeller concludes that "The CISG is as close to a uniform instrument as

\footnotetext{
${ }^{305}$ Ibid, Bridge also goes on to argue: "Uniform law, on the other hand, is new and therefore unpredictable. Archaic law may be dispensed with along the way but the abbreviated nature of the diplomatic process leading to instruments like the CISG often compels the acceptance of what some would consider to be second-best in pursuit of the higher goal that something of value come out of the process. Furthermore, the reduction of transaction costs as parties no longer negotiate over the applicable law is more apparent than real if they negotiate instead over whether to exclude the CISG from their contractual dealings. The development of uniform law comes at a cost to litigants; the law created by the resolution of their disputes subsidizes those who come after them."

306 Ibid, 508.

${ }^{307}$ Petra Butler, above n80, 64-65: "The CISG is the more modern document taking into account today's international (and it would seem, domestic) commercial reality".

${ }^{308}$ Luke Nottage, above n4, 69-70.
} 
it possibly can be ${ }^{, 309}$. He argues that the CISG is supported by an "institutional system" which is "backed by the publication of decided international cases" and "its own community of interpreters, who bases their decisions on a real world of international trade" ${ }^{\text {310 }}$. This view accords with the conclusions reached as a consequence of the present analysis. The analysis of the Vis Moot case studies, and the vast amount of CISG-specific jurisprudence the memoranda rely on, demonstrate that in general the reported decisions, scholarly opinion and the manner in which the emerging young lawyers are applying these sources, follow a uniform approach and very seldom rely on domestic laws. The CISG has developed a substantive body of distinct precedent. The Vis Moot is certainly an important part of the "institutional system" referred to by Zeller as being the pillar which supports the CISG. One tangible jurisprudential outcome of the Vis Moot is the Vindobona Journal of International Commercial Law and Arbitration, published bi-annually by the Moot Alumni Association of the Vis Moot, which publishes articles on current CISG and international arbitration issues.

\section{B Mapping Major Trends \& Jurisprudential Outcomes}

The analysis conducted in this dissertation draws out several substantive conclusions. In the first instance, a survey of the leading academic writing on the CISG, together with that of the issues raised in the seventeen Vis Moot problems sets certain provisions quite clearly apart in terms of their importance and contentiousness. Secondly, the consideration of the interpretative problems arising in relation to each such provision provides some clarity on the aspects of its application which have become well established as well as those areas where gaps still exist. Finally, the analysis illuminates what the current "hot topics" are. These three outcomes are discussed in turn below.

\footnotetext{
${ }^{309}$ Bruno Zeller CISG and the Unification of International Trade Law (Routledge-Cavendish, Oxford/New York, 2007), 107.

${ }^{310} \mathrm{Ibid}$.
} 
$1 \quad$ Key Issues debated \& reconsidered

The Vis Moot casebook mirrors the development of CISG jurisprudence. Over the past seventeen years clear trends have emerged indicating the most contentious issues arising out of international sale of goods contracts, and consequently the areas of the CISG that are most commonly applied in disputes between the parties to such contracts. Several reasons emerge for the repetition and common occurrence of certain issues, and a revisiting of particular provisions over the years. Primarily, certain issues lie at the heart of sale of goods contracts, for example whether the goods are in conformity with the contract, and as such are bound to arise regularly. Secondly, particular provisions are key mechanisms in the application of the Convention. For example, Article 8 is bound to be applied in most CISG disputes due to its all encompassing reach across all areas of the Convention. The dispute is likely to require interpretation of the contract, the parties' conduct and their intentions on some level and Article 8 will play a key role in providing the parties with interpretative guidance. Another example of a key mechanism is Article 25. More often then not one party will want to avoid the contract altogether, rather than rely on other remedies under the CISG. The fundamental breach test plays a major role in such situations, and as such is bound to be used on a regular basis in contractual disputes. Thirdly, certain aspects of the Convention remain unsettled, yet occur regularly. This is the case with Article 79. Force majeure-type impediments precluding performance arise regularly in international sale of goods transactions, yet the application of Article 79 still appears to be in its inception. As such, issues of unforeseeable impediments beyond one's control recur in regular intervals in the Vis Moot, and are in fact at the forefront in the current, seventeenth, Vis Moot problem. Even those provisions whose application has been explored in-depth over the years and where vast amounts of precedent and opinion exist will, from time to time, re-emerge with unexpected gaps in interpretation. One such example analysed in the current paper concerns the recent developments in interpretation of Article 35, in particular around specific issues of applicability of different standards and conformity of goods in light of public allegations as to their quality and safety. The final aspect influencing recurrence of key themes is the Vis Moot's educational role. This event introduces thousands of up-and-coming CISG practitioners and scholars to the operation of the Convention annually. As such, recurrence of key issues and provisions is of great educational importance. 
The key contentious areas of the CISG identified in this dissertation concern interpretation under Article 8, formation of contract, conformity of goods, fundamental breach as a precondition of avoidance and exemptions from liability for damages due to force majeure type events.

Article 8 is a common feature of any CISG dispute. It touches on most aspects of the interpretation of the Convention, and is an indispensible guide on contract interpretation. Uniform application of the principles it introduces is therefore of major importance for the CISG evolution. It introduces new concepts for both common and civil lawyers. For example, the fact that both pre-contractual negotiations and subsequent conduct may be taken into account when interpreting the contract and the parties' intentions requires a substantial shift in thinking for common lawyers. The specific test under Article 8(2) of a "reasonable person in the same type of business" is also a new concept for practitioners from both legal traditions. It is a CISG specific interpretation mechanism. However, as may be deduced from the above discussion, CISG jurisprudence on the application of Article 8 has matured considerably over the years, and the impression one gets from the more recent memoranda is that the newly emerging CISG lawyers are applying this article with confidence and skill. A great testament to the development of Article 8 is its mention and support in a couple of New Zealand cases ${ }^{311}$, particularly given the scarcity of CISG-related case law in New Zealand ${ }^{312}$.

Issues of contract formation have arisen regularly, although scarcely. Formation of contract provisions, namely Articles 14-24 have two key features in common. The first one being that formation doctrines vary widely between different jurisdictions, and the CISG provisions on

\footnotetext{
${ }^{311}$ Yoshimoto v Canterbury Golf International Ltd [2001] 1 NZLR 523 (CA), per Thomas J, para 88: "It would, of course, be open to this Court to seek to depart from the law as applied in England on the basis of this country's implementation in 1995 of the United Nations Convention on Contracts for the International Sale of Goods. Liberal provisions for the interpretation of international sales contracts are included in this Convention." and AttorneyGeneral v Dreux Holdings Ltd (1996) 7 TCLR 617.

312 There are only six reported cases in New Zealand which mention the CISG: Attorney-General v Dreux Holdings Ltd (1996) 7 TCLR 617; Tri-Star Customs and Forwarding Ltd v Denning [1999] 1 NZLR 33; Integrity Cars (Wholesale) Ltd v Chief Executive of New Zealand \& anor [2001] NZCA 86 (2 April 2001); Yoshimoto $v$ Canterbury Golf International Ltd [2001] 1 NZLR 523 (CA); Thompson v Cameron HC Auckland (27 March 2002) AP117/SW99 (Chambers J); KA (Newmarket) Ltd v Hart HC Auckland (4 July 2002) CP 467-SD01 (Heath J); International Housewares (New Zealand) Ltd v SEB SA HC Auckland (31 March 2003) CP 395-SD01 (Master Lang).
} 
formation have generally been created as a result of compromises reached during the drafting process. The second feature is a general lack of reported decisions on these provisions, and consequently a much lesser amount of scholarly opinion on their interpretation in comparison to other areas of the $\mathrm{CISG}^{313}$. Considering the issues of interpretation of these provisions to various factual scenarios over the years of the Vis Moot, whether the lack of reported decisions in this area illustrates their success or not is not entirely clear. The Vis Moot problems have at least highlighted several interpretative issues, such as the relationship between Articles 14 and 55 and the issues of their application. A review of the reported decisions on the application of Articles 14 and 55, it is evident that the intended "gap filler" Article 55 does not achieve its purpose, since the factual scenarios where these two provisions co-exist as they may have been intended to are extremely rare. This is an area that could certainly benefit from further jurisprudential development. Another issue with the scarcity of developed principles in the area of contract formation is the danger of the so-called "homeward trend", namely that the courts will be inclined to resort to domestic doctrines in an attempt to interpret these provisions where CISGspecific interpretative aids are unavailable. This was clearly the case in certain Vis Moot submissions ${ }^{314}$ and is not an ideal position.

Conformity of goods with the contract is possibly the most fundamental CISG provision. Whether the goods conform to the contract will be at the forefront of each seller's and buyer's mind when concluding a contract for sale and purchase of goods. Not surprisingly, the rules on conformity have been interpreted through numerous reported decisions and scholarly commentaries. These questions have featured prominently throughout the years of the Vis Moot, and the manner in which the issues in the competition have evolved is a testament to the highly developed jurisprudence in this area. The general principles of the rules contained in Article 35 are, by now, well established. The CISG community has moved towards the exploration of very specific, very high-level, sophisticated issues arising in relation to the provisions on conformity, and this focus has clearly been demonstrated in the recent years of the Vis Moot. Article 35 may be deemed a success of the CISG, and perhaps due to its core importance to this document, illustrates the Convention's wider success in the past couple of decades.

\footnotetext{
${ }^{313}$ Please refer to Part III, B, Chapter 2 above.

${ }^{314}$ For example in the University of California, Berkley School of Law Memorandum for Claimant in the Fifteenth Vis Moot.
} 
Fundamental breach as a precondition of contract avoidance has also seen a vast amount of reported decisions and commentary develop over the years. Much like issues of conformity, it has evolved towards a more focussed, sophisticated interpretation problematic. The question whether a breach is fundamental is ultimately one of fact, and the general categories of common factual scenarios have been reasonably well established through reported decisions. Certain specific issues remain open, such as the impact of the offer to cure on the existence of a fundamental breach, although overall this provision is another example of a successful development of CISG-specific jurisprudence.

The final issue that has been subject of analysis is that of so-called force majeure, or, more precisely the provision dealing with the exemption of the defaulting party from liability to pay damages where it has failed to perform due to an unforeseen impediment beyond its control. This has been, and remains, one of the least successful provisions of the CISG ${ }^{315}$. This exemption has been an area of continuous controversy over the years, since the parties often wish to rely on it, but the courts have seldom found that a party in default will be exempted under it. The thresholds applied are very high, and it appears that the prevailing opinion remains that, where the parties are concerned about impediments that may preclude performance, they ought to provide specific force majeure provisions in their contracts to that effect. Relying solely on Article 79 is unlikely to have a satisfactory effect in case of unforeseen impediments. Another question remains open in relation to the main premise of Article 79, namely that even where a party is excused under it; it is only excused from paying damages. The practical difficulties of being required to perform in situations where (full) performance is not possible have been debated continuously. Article 79 is certainly one area of the CISG which could only benefit from further jurisprudential development. This is also demonstrated by the fact it is to be the topic of debate in Vienna once again in the current Vis Moot.

\footnotetext{
${ }^{315}$ Honnold, above n39, 483-484.
} 
The current, seventeenth Vis Moot problem very clearly encapsulates the conclusions drawn out above. In involves a wide array of existing issues which have been identified as ongoing and builds on the key themes, particularly issues of compliance with particular standards in a jurisdiction that is not the seller's (nor the buyers in this instance), and the issues with application of Article 79. This problem concerns an order by Claimant from Respondent of various water pumps for an irrigation project in a third jurisdiction. The parties had an established relationship as they worked on a similar project previously. The contract was concluded, following which all manner of complications arose. A change in regulations occurred in the jurisdiction where the water pumps would ultimately be used, and Claimant had to procure some new goods in order to satisfy them. This lead to a delay in shipment, which was subject to further substantial delays due to collision of other ships en route and closure of the main waterway, during which delays a military takeover took place in the country for which the goods were destined, the new government implemented new regulations rendering the goods illegal for their purpose and cancelling its contract with Respondent for which purpose the goods were purchased. Respondent sought to avoid the contract. This problem touches on all key issues identified and canvassed in this dissertation. Was Claimant in breach of contract due to late delivery? Was the late delivery excused under Article 79? Was Claimant in breach for delivering goods which were not in conformity with the contract as a result of new regulations rendering them illegal for use? If there was a breach, was it fundamental so as to justify avoidance? The arguments in response to such questions which will be presented next year in Vienna are awaited with anticipation, and the outcomes of the debate will likely result in new academic opinions paving the way for further development of CISG principles. 
The Vis Moot has played a key role in the promotion of the CISG, and there is little doubt that it has achieved its initial purpose ${ }^{316}$. It has been an important tool in the promotion of a uniform application of the CISG and an indoctrination of young, soon-to-be lawyers into the conceptual framework of the Convention. A survey of the memoranda submitted over the sixteen years of the competition demonstrates that the new generations of CISG scholars are emerging at an ever growing rate and that these new generations are putting aside the homeward trends and moving away from relying on domestic doctrines in the interpretation of the CISG provisions. They are approaching the Convention with a fresh perspective and adopting its spirit by relying primarily on the document itself together with the vast amount of scholarly material and reported decisions which are easily available. The Vis Moot problems, memoranda and the publications emerging from this event are a great tribute to Article 7(1) of the CISG and the overall spirit of the Convention.

The Vis Moot has produced, and keeps producing, generations of CISG and international arbitration lawyers. The students participating in the Vis Moot gain a thorough understanding of the operability of the CISG and its relation to international arbitration. Once the students leave university, they take this knowledge with them to their working lives, whether as practitioners, judges, arbitrators or academics. The Vis Moot therefore achieves its objective of promoting the CISG and raising awareness of its applicability, by creating a worldwide legal community with deep and thorough knowledge of this document, and a host of young lawyers willing and proactive in applying it to future international transactions in which they may get involved. Schlechtriem wrote in $2005^{317}$ :

The United Nations Convention on Contracts for the International Sale of Goods (CISG) has become a tremendous success story, unexpected even by its staunchest supporters... Tens of thousands of law students all around the world are instructed in international sales law, and many become experts on the CISG by participating in the annual Willem $\mathrm{C}$ V is moot competition

\footnotetext{
${ }^{316}$ Eric E. Bergsten, above $\mathrm{n} 1,481$, the initial purpose having been promotion of, and education on, the CISG.

${ }^{317}$ Peter Schlechtriem "Basic Structures and General Concepts of the CISG as Models for a Harmonisation of the Law of Obligations" (2005) 10 Juridica International 27-34, 27.
} 
In addition to promoting the CISG and educating young lawyers, the Vis Moot is of great importance to the wider CISG community as the central global forum where new ideas are tested, where academic discussion and exchange regularly occurs and the flow of information in the global context is enhanced. No doubt, as the Vis Moot continues to grow and expand in the coming years, its impact will grow and expand accordingly while an ever increasing number of academics and practitioners continue to engage in this annual event to further explore the captivating aspects of the continuously evolving CISG jurisprudence. 


\section{BIBLIOGRAPHY}

\section{A Court Decisions}

$1 \quad$ Austria

Oberster Gerichtshof 20 March 1997 (Mono ammonium phosphate case)

Oberster Gerichtshof 2 Ob 163/97b, 11 March, 1999 (Frames for mountain bikes case)

Oberster Gerichtshof $10 \mathrm{Ob} 344 / 99 \mathrm{~g}, 21$ March 2000 (Wood case)

Oberster Gerichtshof 7 September 2000 (Tombstones case)

2 France

Cour d'appel, Grenoble 13 September 1995

Cour d'appel, Grenoble 26 April 1995

Cour de Cassation 23 January 1996

$3 \quad$ Germany

Amtsgericht Duisburg 13 April 2000 (Pizza cartons case)

Bundesgerichtshof 8 March 1995 [VIII ZR 159/94] (The Mussels case)

Bundesgerichtshof 3 April 1996 [VIII ZR 51/95] (Cobalt sulphate case) 
Bundesgerichtshof 24 March 1999 (Vine wax case)

Bundesgerichtshof 31 October 2001 [VIII ZR 60/01] (Machinery case)

Bundesgerichtshof Germany, 9 January 2002 (Powder milk case)

Bundesgerichtshof 2 March 2005 [VIII ZR 67/04] (Frozen pork case)

Landgericht Berlin 15 September 1994 (Shoes case)

Landgericht München 8 February 1995 (Standard software case)

Landgericht Landshut 5 April 1995

Landgericht Darmstadt, 9 May 2000 (Video recorders case)

Landgericht München [5HK O 3936/00], 27 February 2002 (Globes case)

Oberlandesgericht Innsbruck 1 July 1994

Oberlandesgericht Frankfurt a.M. 18 January 1994

Oberlandesgericht Düsseldorf 24 April 1997 (Shoes case)

Oberlandesgericht Celle 24 May 1995 (Used printing press case)

Oberlandesgericht Koblenz 31 January 1997 (Acrylic blankets case)

Oberlandesgericht Hamburg 28 February 1997 (Iron molybdenum case)

Oberlandesgericht München 15 September 2004 (Furniture leather case) 
Pretura circondariale de Parma 24 November 1989

Pretura Circodariale di Fidenza, (Foliopack v. Daniplast), 24 November 1989

Corte di Appello di Milano 20 March 1998

Tribunale di Busto Arsizio 13 December 2001

$5 \quad$ New Zealand

Attorney-General v Dreux Holdings Ltd (1996) 7 TCLR 617.

Tri-Star Customs and Forwarding Ltd v Denning [1999] 1 NZLR 33.

Integrity Cars (Wholesale) Ltd $v$ Chief Executive of New Zealand \& anor [2001] NZCA 86 (2 April 2001).

Yoshimoto v Canterbury Golf International Ltd [2001] 1 NZLR 523 (CA).

Thompson v Cameron HC Auckland (27 March 2002) AP117/SW99 (Chambers J).

KA (Newmarket) Ltd v Hart HC Auckland (4 July 2002) CP 467-SD01 (Heath J).

International Housewares (New Zealand) Ltd vSEB SA HC Auckland (31 March 2003) CP 395-SD01 (Master Lang).

$6 \quad$ Switzerland

Appellationsgericht Basel-Stadt, 22 August 2003 (Soyprotein products case), 
Bundesgericht 28 October 1998 (Meat case)

Bundesgericht 22 December 2000, 4C.296/2000 (Roland Schmidt GmbH v. TextilWerke Blumenegg AG)

Bundesgericht 15 September 2000 (FCF v Adriafil)

Handelsgericht des Kantons St. Gallen 5 December 1995 (Computer hardware devices case)

Handelsgericht des Kantons Zürich 10 July 1996 (Plastic chips case)

Handelsgericht des Kantons Zürich 30 November 1998 (Lambskin coat case)

Handelsgericht des Kantons Zürich 26 April 1995 (Saltwater isolation tank case)

Bezirgericht St. Gallen, 3 July 1997 (Fabrics case)

Richteramt Laufen des Kantons Berne, 7 May 1993 (Automatic storage system case)

Richteramt Laufen des Kantons Berne, 7 May 1993

$7 \quad$ United Kingdom

Bank of Australasia v Palmer [1987] AC 540.

$8 \quad$ United States

Filanto S.p.A. v. Chilewich Int'l Corp. 91 Civ. 3253 (CLB) 1992 
Magellan International v. Salzgitter Handel GmbH, No. 99 C 5153 United States District Court for the Northern District of Illinois, Eastern Division December 7, 1999

MCC-Marble Ceramic Center v. Ceramica Nuova Dágostino 144 F.3d 1384 (11th Cir. 1998)

Medical Marketing v Internazionale Medico Scientifica. S.r.l.; No. Civ. A. 990380, 1999 WL 311945 (E.D. La. May 17, 1999)

\section{B Arbitral Awards}

$1 \quad$ Austria

Schiedsgericht der Börse für landwirtschaftliche Produkte in Wien Arbitration, 10Dec-1997, CISG-online 351, S 2/97

2 Bulgaria

Bulgarian CCI Ct Arb, 12 February 1998

3 Germany

Schiedsgericht der Handelskammer Hamburg, Germany, Arbitral Award, 21 March 1996

$4 \quad$ International Chamber of Commerce

ICC Court of Arbitration, Arbitration Case No. 6281 of 1989 (Steel bars case) 
ICC Court of Arbitration, Award 7585 of 1992 (Foamed board machinery)

ICC Court of Arbitration, Award No. 8213, March 1995 (Steel billets case)

ICC Court of Arbitration, Award 8786 of January 1997 (Clothing case)

$5 \quad$ Russia

Tribunal of International Commercial Arbitration at the Russian Federation Chamber of Commerce, Award 387/1995, 4 April 1997

Tribunal of International Commercial Arbitration at the Russian Federation Chamber of Commerce and Industry, Arbitration proceeding 155/1994 (Metallic sodium case), 16 March 1995

6 The Netherlands

Netherlands Arbitration Institute, Award 2319 of 15 October 2002

\section{Legal Texts}

$1 \quad$ European Union

Principles of European Contract Law (PECL), prepared by the Commission on European Contract Law, Parts I and II revised 1998, Part II 2002.

Directive 1999/44/EC of the European Parliament and of the Council of 25 May 1999 on certain aspects of the sale of consumer goods and associated guarantees

Directive 2001/95/EC of the European Parliament and of the Council of 3 December 2001 on general product safety 
2 International Chamber of Commerce

International Commercial Terms of the ICC revised in 2000 (Incoterms 2000)

$3 \quad$ New Zealand

Sale of Goods (United Nations Convention) Act 1994.

$4 \quad$ United Kingdom

Sale of Goods Act 1979 (UK).

$5 \quad$ United Nations

United Nations Convention on Contracts for the International Sale of Goods (11 April 1980) 1489 UNTS 3.

UNIDROIT Principles of International Commercial Contracts

$6 \quad$ United States

Uniform Commercial Code

D Secondary sources

$1 \quad$ Texts

Bianca, Cesare Massimo and Bonell, Michael Joachim (eds) Commentary on the International Sales Law: The 1980 Vienna Sales Convention (Giuffré, Milan 1987). 
Bridge, Michael The International Sale of Goods Law and Practice (2 ${ }^{\text {nd }}$ ed) (Oxford University Press, Oxford/New York, 2007).

Enderlein, Fritz and Maskow Dietrich International Sales Law: United Nations Convention on Contracts for the International Sale of Goods, Convention on the Limitation Period in the International Sale of Goods (Oceana, New York, 1992).

Ferrari, Franco (ed.) The CISG and its Impact on National Legal Systems (Sellier, 2008).

Honnold, John O. Uniform Law for International Sales under the 1980 United Nations Convention ( $3^{\text {rd }}$ ed) (Kluwer Law International, The Hague, The Netherlands, 1999).

Lookofsky, Joseph Understanding the CISG in Europe, (2 ${ }^{\text {nd }}$ ed), (Kluwer Law International, 2004).

Neumayer, Karl and Ming, Catherine Convention de Vienne sur les Contracts de Vente Internationale de Merchandise (CEDIDAC, Lausanne 1993).

Saidov, Djakhongir The Law of Damages in International Sales, the CISG and other international documents (Hart Publishing, Portland, USA, 2008).

Schlechtriem, Peter (ed) Commentary on the UN Convention on the International Sale of Goods (CISG) ( $2^{\text {nd }}$ ed (in translation)) (Clarendon Press, Oxford, 1998).

Schlechtriem, Peter and Schwenzer, Ingeborg (eds) Commentary on the UN Convention on the International Sale of Goods (CISG) ( $2^{\text {nd }}$ (English) ed) (Oxford University Press, Oxford/New York, 2005). 
Schlechtriem, Peter and Butler, Petra UN Law on International Sales, the UN Convention on the International Sale of Goods (Springer-Verlag, Berlin, Heidelberg, 2009).

Šarčević, Petar and Volken, Paul (ed) The International Sale of Goods Revisited (Kluwer Law International, 2001).

Zeller, Bruno CISG and the Unification of International Trade Law (RoutledgeCavendish, Oxford/New York, 2007).

Journals

Andersen, Camilla "The Global Jurisconsultorium of the CISG Revisited" (2009) 13 VJ 43.

Andersen, Camilla Baasch "Exceptions to the Notification Rule - Are They Uniformly Interpreted?" (2005) 9 VJ 17.

Bainbridge, Stephen "Trade Usages in International Sales of Goods: An Analysis of the 1964 and 1980 Sales Conventions" (1984) 24 Va J Int'I L 619.

Basedow, Jürgen "Towards a Universal Doctrine of Breach of Contract: The Impact of the CISG" (2005) 25 Int'l Rev L \& Econ 487.

Behr, Volker "The Sales Convention in Europe: From Problems in Drafting to Problems in Practice" (1998) 17 J L \& Com 263.

Bergsten, Eric E "Teaching about International Commercial Law and Arbitration: the Eight Annual Willem C. Vis International Commercial Arbitration Moot" (2001) $18 \mathrm{~J}$ Int Arbitrat No. 4, 481. 
Bund, Jennifer "Force majeure Clauses: Drafting Advice for the CISG" J L \& Com (1998), 381.

Butler, Petra "Celebrating Anniversaries" (2005) 36 VUWLR 775.

Butler, Petra "The Doctrines of Parol Evidence Rule and Consideration - A Deterrence to the Common Law Lawyer" in "Celebrating Success: 25 Years United Nations Convention on Contracts for the International Sale of Goods" (SIAC, Singapore, 2006).

Ferrari, Franco "Homeward Trend and Lex Forism Despite Uniform Sales Law" (2009) 13 VJ 15.

Ferrari, Franco "Uniform Application and Interest Rates under the 1980 Vienna Sales Convention" 24 GA J Int'l \& Comp Law, 467.

Franco Ferrari "Fundamental Breach of Contract Under the UN Sales Convention - 25 Years of Article 25 CISG" 25 JL \& Com (Spring 2006) 489-508.

Ferreri, Silvia "Remarks Concerning the Implementation of the CISG by the Courts (the Seller's Performance and Article 35)" (2005-06) 25 J L \& Com 223.

Graves, Jack M and Vaughan, Stephanie A "The Willem C Vis International Commercial Arbitration Moot: Making the Most of an Extraordinary Educational Opportunity" (2006) 10 VJ 173.

Hahnkamper, Wolfgang "Acceptance of an offer in light of electronic communications" (2005-06) $25 \mathrm{~J}$ L \& Com 147. 
Joseph Lookofsky "1980 United Nations Convention on Contracts for the International Sale of Goods" published in International Encyclopaedia of Laws Contracts, Suppl. 29 December 2000, 1.

Nottage, Luke "Who's Afraid of the Vienna Sales Convention (CISG)? A New Zealander's View from Australia and Japan" (2005) VUWLR 39.

Schlechtriem, Peter "Legal Costs as Damages in the Application of UN Sales Law" (2006-7) 26 J L \& Com 71.

Schlechtriem, Peter "Basic Structures and General Concepts of the CISG as Models for a Harmonisation of the Law of Obligations" (2005) 10 Juridica International 27.

Schlechtriem, Peter "Requirement of Application and Sphere of Applicability of the CISG" (2005) 4 VUWLR 781.

Schlechtriem, Peter "Subsequent Performance and Delivery Deadlines Avoidance of CISG Sales Contracts Due to Non-conformity of Goods" (Spring 2006) 18 Pace Int'l L Rev, Issue No. 1, 83.

Schwenzer, Ingeborg "The Danger of Domestic Pre-Conceived Views with Respect to the Uniform Interpretation of the CISG: The Question of Avoidance in the Case of Non-Conforming Goods and Documents" (2005) 36 VUWLR 795.

Schwenzer, Ingeborg "Avoidance of the contract in case of non-conforming goods (Article 49(1)(a) CISG)" (2005-06) 25 J L \& Com 437. 
Andersen, Camilla Baasch "Reasonable Time in Article 39(1) of the CISG - Is Article 39(1) Truly a Uniform Provision?" available at: http://www.cisg.law.pace.edu/cisg/biblio/andersen.html

CISG-AC Opinion No.1 "Electronic Communications under CISG", 15 August 2003. Rapporteur: Professor Christina Ramberg, Gothenburg, Sweden, available at: http://www . cisgac.com/default.php?ipkCat $=128 \&$ ifkCat $=143 \&$ sid $=143$

CISG-AC Opinion No.2 "Examination of the Goods and Notice of NonConformity: Articles 38 and 39, 7 June 2004". Rapporteur: Professor Eric E. Bergsten, Emeritus, Pace University School of Law, New York., available at: http://www.cisgac.com/default.php?ipkCat $=128 \&$ ifkCat $=144 \&$ sid $=144$

CISG-AC Opinion No.3 "Parol Evidence Rule, Plain Meaning Rule, Contractual Merger Clause and the CISG, 23 October 2004. Rapporteur: Professor Richard Hyland, Rutgers Law School, Camden, NJ, USA, available at: http:/www.cisgac.com/default.php?ipkCat $=128 \&$ ifkCat $=145 \&$ sid $=145$

CISG-AC Opinion No. 4 "Contracts for the Sale of Goods to Be Manufactured or Produced and Mixed Contracts (Article 3 CISG)", 24 October 2004. Rapporteur: Professor Pilar Perales Viscasillas, Universidad Carlos III de Madrid, available at: http://www.cisgac.com/default.php?ipkCat $=128 \&$ ifkCat $=146 \&$ sid $=146$

CISG-AC Opinion No. 5 "The buyer's right to avoid the contract in case of nonconforming goods or documents", 7 May 2005, Badenweiler (Germany).

Rapporteur: Professor Dr. Ingeborg Schwenzer, LL.M., Professor of Private Law, University of Basel, available at:

http://www.cisgac.com/default.php?ipkCat $=128 \&$ ifkCat $=147 \&$ sid $=147$ 
CISG-AC Opinion No. 6 "Calculation of Damages under CISG Article 74", Rapporteur: Professor John Y. Gotanda, Villanova University School of Law, Villanova, Pennsylvania, USA, available at: http://www.cisgac.com/default.php?ipkCat $=128 \&$ ifkCat $=148 \&$ sid $=148$

CISG-AC Opinion No. 7 "Exemption of Liability for Damages under Article 79 of the CISG", Rapporteur: Professor Alejand ro M. Garro, Columbia University School of Law, New York, N.Y., USA, available at:

http:/www.cisg.law.pace.edu/cisg/CISG-AC-op7.html

CISG-AC Opinion No. 8 "Calculation of Damages under CISG Articles 75 and 76", Rapporteur: Professor John Y. Gotanda, Villanova University School of Law, Villanova, Pennsylvania, USA. Adopted by the CISG-AC following its 12th meeting in Tokyo, Japan, on 15 November 2008, available at: http: $/ /$ www.cisgac.com/default.php?ipkCat $=128 \&$ ifkCat $=148 \&$ sid $=184$

CISG-AC Opinion No. 9 "Consequences of Avoidance of the Contract", Rapporteur: Professor Michael Bridge, London School of Economics, London, United Kingdom. Adopted by the CISG-AC following its 12 th meeting in Tokyo, Japan on 15 November 2008, available at:

http://www.cisgac.com/default.php?ipkCat $=128 \&$ ifkCat $=148 \&$ sid $=185$

Henschel, René Franz "Interpreting or supplementing Article 35 of the CISG by using the UNIDROIT Principles of International Commercial Contracts and the Principles of European Contract Law", available at: http:/www.cisg.law.pace.edu/cisg/biblio/henschel.html

Caruba, Sandra L "Globalisation as a nexus between the historical narratives of international law and commercial law" (2006) 3 NZPGLEJ, available at: http:/www.nzpostgraduatelawejournal.auckland.ac.nz/Back\%20Issues/Issue $\% 203$ $\% 20 \% 282006 \% 29 /$ Article $3 \% 20$ Issue $3 . h t m$ 
Institute of Foreign and International Private Law (Dept. 1) at the University of Freiburg, Germany, CISG-online database, available at:

http://www.globalsaleslaw.org/index.cfm?pagelD $=28$

Liu, Chengwei "Effects of Avoidance: Perspectives from the CISG, UNIDROIT Principles and PECL and case law" available at:

http://www.cisg.law.pace.edu/cisg/biblio/liu12.html

Mistelis, Loukas "CISG-AC Publishes First Opinion", available at: http://www.cisg-online.ch/cisg/docs/CISG-\%20AC_Mistelis intro.pdf

Pace Law School, Institute of International Commercial Law, CISG Database, available at: http://www.cisg.law.pace.edu/

Schlechtriem, Peter and Viscasillas, Pilar PErales "Case note on decision of Court of First Instance of Tudela (Spain)" 2005, available at:

http://www.cisg.law.pace.edu/cisg/biblio/perales4.html

Schlechtriem, Peter "Commentary - Compliance with local law; seller's obligations and liability, Annotation to German Supreme Court decision of 2 March 2005 [VIII ZR 67/04]", available at: http://www.cisg.law.pace.edu/cisg/biblio/schlechtriem7.html (a translation of a German case note in Juristenzeitung 2005, 846-848).

Schlechtriem, Peter "Interpretation, gap-filling and further development of the UN Sales Convention", available at:

http://www.cisg.law.pace.edu/cisg/biblio/schlechtriem6.html 
Schlechtriem, Peter "From the Hague to Vienna: Progress in Unification of the Law of International Sales Contracts?" available at:

http://www.cisg.pace.edu/cisg/biblio/schlechtriem13.html

Schlechtriem, Peter "The Seller's Obligations Under the United Nations Convention on Contracts for the International Sale of Goods", available at: http://cisgw3.law.pace.edu/cisg/biblio/schlechtriem 10. html

Sukhbaatar, Sumiya ""Missing Information":Inquiry into the CISG" available at: http://www.cisg.law.pace.edu/cisg/biblio/sukhbaatar.html

UNCITRAL Home Page on the CISG, available at:

http:/www.uncitral.org/uncitral/en/uncitral texts/sale_goods/1980CISG.html

UNCITRAL Digest of case law on the United Nations Convention on the International Sale of Goods, available at:

http://www.cisg.law.pace.edu/cisg/text/digest-toc.html

$4 \quad$ Vis Moot Materials

1 - 17 Vis Moot Problems and Winning Memoranda are available at: http://www.cisg.law.pace.edu/vis.html 


\section{APPENDIX I - FACT SUMMARIES}

This appendix contains fact summaries of the seventeen Vis Moot problems. The problems are named based on goods in dispute for ease of reference.

\section{A FIRST VIS MOOT-Super Sexto Computer Chips}

- Claimant, Quinto Computer Company is incorporated in Equatoria, and is a manufacturer of personal computers.

- Respondent, Sexto Chip Company is incorporated in Mediterraneo and is a manufacturer of computer chips.

- Early 1992 - January 1993: Respondent was developing a new computer chip the "SuperSexto" and shared development information with its major customers so as to allow them to design new computers that would take advantage of the features of the new chip.

- 15 January 1993: Respondent entered into a contract with Claimant (and other of its seven major customers) for sale of a minimum of 2,500 SuperSexto chips per month during the introductory period being 15 January 1993 - 1 July 1994 (and a total of 25,000 chips) at a factory price of US\$525 per chip. Across all eight contracts Respondent agreed to deliver a total of 175,000 SuperSexto chips during the introductory period.

- 15 August: Respondent had manufactured and placed in its warehouse 220,000 chips ready for shipment, but a fire broke out in its factory and warehouse and only 80,000 chips survived. The factory was damaged and Respondent did not expect to resume production until 1 July 1994.

- 17 August: Respondent wrote Claimant (and other seven customers) informing them it intends to delay shipping of the chips until its factory is back in production and that it will notify it when the new introductory period will begin.

- 20 August: Claimant wrote Respondent stating it cannot wait for the delayed shipping as it has developed a computer for the particular purpose of using the new chip and that any 
delays would lead to intolerable losses. It demanded that Respondent deliver the chips it had in stock within the time period that was initially agreed.

- 28 August: Respondent wrote Claimant informing it that it cannot give it a competitive advantage by sending it the chips in stock until it has a sufficient amount for all of its eight customers with whom it has contracted.

- 6 September: A report was issued by the fire department stating the cause of the fire was a short circuit for which Respondent could not be blamed. Respondent was at the time in the process of installing a new alarm and sprinkler system, meaning that both the old and the new system were turned off at the time of the fire.

- 1 October: Claimant sent Respondent its notice of arbitration.

\section{SECOND VIS MOOT - X-23 mobile telecommunications base stations}

- Claimant, Communications Corporation is incorporated in Equatoriana and is a relatively small manufacturer of specialised telecommunications equipment which it sells in twenty different countries.

- Respondent, Specialty Electornics Corporation is incorporated in Mediterraneo and is a manufacturer of electronic components, which it sells to a number of manufacturers of various types of electronic equipment.

- 26 August 1991: Claimant and Respondent entered into an agreement for the sale of electronic components, and also for the use of electronic data interchange (EDI) for sending of purchase orders, invoices and similar routine business communications.

- 3 March 1994: Claimant telephoned Respondent to order 120 A-14 resonators by air. Claimant informed Respondent that it has entered into a contract to sell to another company, World Wide Telecommunications ("WWT") its X-23 mobile communications base stations, by providing 50 units within two months for testing, subject to success of which, it would provide an additional 10,000 units within the next two years. Claimant further stated that it would require 120 A14 resonators, which it purchased regularly in the past, to manufacture the $50 \mathrm{X}-23$ base stations. Respondent confirmed it will send the 120 A-14 resonators that same day.

- 9 March: Claimant receives 120 A-14 resonators. 
- 12 April: 50 X-23 mobile base stations delivered to WWT after routine testing on A-14 resonators by Claimant and assembly.

- 5 May: WWT notified Claimant that it found upon testing that the X-23 mobile base stations did not work properly in certain rare, but important, situations and that therefore it will not take the 10,000 additional units.

- 24 May: President of Claimant's company telephoned president of Respondent to inform them that, upon investigation it was found that the issue with the $X-23$ mobile base stations was found to lie with the A-14 resonators which were modified by Respondent without having informed Claimant of such modifications. The modifications did not change any of the published technical specifications, but they did make them incompatible with other components of $\mathrm{X}-23$ in certain performance situations. The two presidents reached an impasse during the telephone conversation.

- 3 October 1994: Claimant sent Respondent its notice of arbitration.

\section{THIRD VIS MOOT - 14C Air Conditioning Units}

- Claimant, Quality Manufacturing Ltd, an Equatorianan company, is a manufacturer of central heating and air conditioning equipment for use in commercial and multi-unit residential buildings with approximately $40 \%$ of its production being exported.

- Respondent, Carlson Heating \& Air Conditioning Co., a Mediterranean company, specialises in the sale, installation and servicing of heating and air conditioning equipment in offices, stores, factories and multiple residence buildings.

- 15 January 1993: Claimant and Respondent concluded the contract for sale of six model $14 \mathrm{C}$ combination heating and air conditioning units at a price of $\$ 50,000$ per unit (total $\$ 300,000)$.

- 15 June: The first unit shipped to Claimant.

- 16 June: Notice of shipment sent by Respondent to Claimant by telex.

- 27 June: The first unit arrives in Mediterraneo and is received by Respondent and transported to the building site at which it is to be installed. 
- 14 July: Claimant received a telex from Respondent in which Respondent confirmed the arrival of the shipment, stated that it was having difficulty getting the unit to work and will provide further details soon.

- 15, 17 and 23 July: Claimant wrote Respondent asking for further details as to the reported malfunction.

- 25 July: Respondent wrote Claimant the control system did not function properly and requested Claimant to repair it. Claimant wrote Respondent that it was shipping by air a replacement system for Respondent to install, as this was significantly cheaper than sending staff to carry out repairs.

- 26 July: Respondent wrote Claimant threatening to go to another supplier if Claimant did not send its personnel to repair the system.

- 27 July: Claimant wrote Respondent stating it had shipped the replacement unit on the previous day and demanding payment for the first unit, less cost to Respondent of installing the replacement parts.

- 30 July: Claimant sent a further telex to Respondent demanding payment of the outstanding balance prior to shipping the next two $14 \mathrm{C}$ units.

- 2 August: Respondent wrote to Claimant purporting to cancel the contract and stated it was holding the unit for Claimant to collect. Claimant replied protesting the cancellation and reiterating it was withholding the second shipment.

- 1 September: Respondent wrote to claimant requesting Claimant to remove the stored unit.

- 1 September 1993 - 10 April 1994: Series of unsuccessful negotiations between the parties.

- 10 April 1994: Respondent sent a telex to Claimant stating it had found a buyer for the unit at the price after repair of $\$ 40,000$ and would sell for the account of Claimant if no reply was received by 17 April.

- 20 April: Respondent sent a further telex stating it was repairing the unit and would sell it once repairs were completed.

- 2 May: Respondent wrote Claimant confirming it had sold the unit for $\$ 40,000$ and would remit to Claimant $\$ 20,900$, being, as it claimed, the difference between the sale price and its alleged costs and damages. 
- 3 May: Claimant wrote Respondent stating it continued to consider Respondent in breach of contract but would settle if Respondent paid the $\$ 50,000$ for the first unit.

- 5 May 1995: Claimant submitted its Request for Arbitration.

\section{FOURTH VIS MOOT-Men's Suits}

- Claimant, Textile Export-Import Co, is incorporated in Mediterraneo, it carries on the business of importing textiles into Mediterraneo for sale to manufacturers of clothing and other finished products, and also sells for export textiles, finished clothing and other finished products made from textiles and manufactured in Mediterraneo. It has no office or agency in Equatoriana.

- Respondent, High Quality Clothes Co, is incorporated in Equatoriana, and owns and operates a chain of 25 retail clothing stores at the high-middle level of price and quality in Equatoriana.

- 1 March 1994: Respondent sent a letter to Men's Suits Manufacturing Co, a company incorporated in Mediterraneo and manufacturing and selling men's outer clothing including suits and pants, ordering 5,000 men's suits of specified models and prices. Men's Suits Manufacturing Co. forwarded the order to Claimant as all of its export sales were handled by Claimant as of 15 February 1994.

- 10 March: Claimant sent to Respondent a confirmation of the order, quoting a price of $\$ 130$ CIP Handelshafen, Equatoriana (Incoterms 1990) per piece for a total of $\$ 650,000$ payable 30 days after shipment. The confirmation also indicated the goods would be shipped directly from Men's Suits Manufacturing Co. on or before 15 August.

1 August: The goods were shipped to Respondent.

- 31 August: Last day by which payment due by Respondent - Respondent didn't make the payment.

- 9 Septem ber: Claimant sent a routine reminder to Respondent regarding payment.

- 10 October: Claimant sent a second reminder to Respondent.

- 14 October: Respondent wrote to Claimant stating the goods were not the same as those ordered by it. 
- 20 October: Claimant wrote to Respondent offering an adjustment to the price and bringing the price down to $\$ 625,000$.

- 27 October: Respondent transferred to Claimant $\$ 390,000$ and wrote to Claimant confirming this was the net sum it obtained when it resold the goods, made up of the resale price of $\$ 500,000$ minus $\$ 110,000$ in costs.

- 4 November: Claimant wrote Repsondent accepting the sum of $\$ 390,000$ as partial payment of $\$ 625,000$ and demanding the payment of the outstanding $\$ 260,000$. Respondent did not make any further payment.

- 5 May 1996: Claimant submits its Request for Arbitration.

\section{E $\quad$ FIFTH VIS MOOT - Drilling rig \#23}

- Claimant, Speculative Drilling Co. is incorporated in the country of Mediterraneo and is engaged in the business of exploring for oil in a number of countries.

- Respondent, Deep Well Drilling Inc. is incorporated in the country of Equatoriana and is also engaged in the business of exploring for oil in a number of countries.

- 15 March - 9 May 1997: Parties carried out negotiations for the sale of rig \#23 by Respondent to Claimant.

- 13 May: Respondent offered to sell to Claimant its drilling rig \#23 for 30,000,000 Equatoriana dollars. Other terms included that price was payable in two amounts, E3,000,000 due to be paid to Respondent within ten days of acceptance of the offer and the balance within five working days prior to delivery of the rig in September 1998. Claimant was required to have a bank guarantee issued by a first class bank in Equatoriana in the sum of E33,000,000 as a payment guarantee within ten days of acceptance of the offer. Claimant had the right to decide whether or not to take the drilling rig until 30 September 1998, and if it decided not to take the rig prior to 15 May it must pay Respondent E3,000,000, and if it decides not to take the rig between 16 May and 30 September it must pay Respondent E4,500,000. Finally, if the drilling rig is resold by Claimant prior to 15 July 2000 it must pay Respondent any profit that might be realised on the sale plus $10 \%$. The offer was open for Respondent to accept or reject by 10 June. 
- 21 May: Claimant wrote Respondent and stated the price of $30,000,000$ was already rejected by it during the negotiations and asked the Respondent to reconsider it.

- 28 May: A large oil field is discovered in Oceania causing the price of rigs to increase immediately by $15 \%$, and by 6 August rose by about $25 \%$.

- 3 June: Respondent sent a fax to Claimant stating that "in light of Claimant's rejection" of its offer of 13 May, Respondent has decided to withdraw the offer. It also stated it would be happy to continue prior negotiations but that in light of changes in the market the rig may not be available for very long.

- 5 June: Claimant replied by fax and accepted the offer of 13 May and stated its letter of 21 May did not constitute a rejection of the offer.

- 6 June: Respondent wrote Claimant that the 5 June telefax was too late as the offer had already been withdrawn.

- 13 June: Claimants payment of E3,000,000 is deposited with Respondent's bank, however this happens after the cut-off time for the bank to credit customers accounts.

- 17 June: Claimants payment of E3,000,000 credited to Respondent's account, after a further delay due to a public holiday in Equatoriana on 16 June. Respondent refused to accept the credit, and Respondent's bank re-transferred the money to Claimant's account where it was deposited on 19 June and where it remained at Respondent's disposal.

- 18 June: The bank guarantee for E33,000,000 issued by the General Credit Bank of Equatoriana.

- 6 August: Claimant submits its Request for Arbitration.

\section{F SIXTH VIS MOOT-Paper making control system}

- Claimant, Superb Paper, Plc is a company organised under the laws of the country of Mediterraneo and is a producer of paper and paper products.

- Respondent, Essential Controls, S.A. is a company organised under the laws of the country of Equatoriana and produces control systems for various manufacturing processes, including production of paper and paper products. 
- 10 June 1996: Claimant and Respondent entered into a contract for Respondent to sell and install in the Claimant's facilities a new system for control of the paper making process for a cost of $\$ 500,000$. Respondent was to complete installation and final testing on or before 16 September 1996. Claimant was to pay $\$ 400,000$ upon delivery of the control system, $\$ 50,000$ within ten days and $\$ 50,000$ within six months of completion of the final testing.

- 20 August: The control system delivered to Claimant.

- 22 August: Payment of $\$ 400,000$ made by Claimant to Respondent.

- 27 August: Respondent telephoned Claimant to inform Claimant that the charter airplane carrying Respondent's team bound for Mediterraneo to install the system has crashed with no survivors.

- 30 August, 4, 9 and 12 September: Claimant telephoned Respondent to inquire when the new installation team may be expected.

- 13 September: Claimant informed Respondent that the contract date for completion of installation and testing was 14 September 1996.

- 18 September: Claimant wrote to Respondent and stated that should the work not be complete by 9 October it will be free to exercise its legal rights.

- 19 September: Respondent replied that it has given its contractor responsible for sending the installation team three weeks to complete the work, or it will seek a new firm to do the work. Respondent inquired whether Claimant would be satisfied to extend the period until 30 October.

- 9 October: Claimant sends Respondent notice avoiding the contract, demanding reimbursement of the $\$ 400,000$ already paid and stating it is storing the computers delivered for Respondent's account.

- 10 October: Claimant concluded a contract with a third party for an installed price of $\$ 550,000$, with installation to be complete within 30 days of contract. Respondent telephoned Claimant to assure it that it had insisted with its contractor that installation will be complete prior to 30 October and the contractor has confirmed it will do so. Respondent confirmed this in a letter the same day. Claimant told Respondent it was too late and the contract was already avoided, and confirmed this in its letter of response the 
same day, reiterating it was holding the computer system as security for repayment of $\$ 400,000$.

- 10 October 1996 - 13 March 1997: Various negotiations over the consequences of the above events.

- 13 March: Claimant wrote to Respondent stating it will sell the computers should it not receive the payment of $\$ 400,000$ within ten days.

- 4 April: Claimant sold the computers for $\$ 250,000$, with costs of storing and preserving the systems prior to sale plus sales costs amounting to $\$ 3,000$, leaving the net receipts of $\$ 247,000$.

- 6 July 1998: Claimant submits its Request for Arbitration.

\section{G SEVENTH VIS MOOT-Standard feed wheat}

- Claimant, Feed Processing Corp. is a company organised under the laws of the country of Mediterraneo.

- Respondent, Grain Dealers PLC. is a company organised under the laws of the country of Danubia.

- 19 February 1998: $\mathrm{Mr}$ Harold Dean, purchasing agent of Claimant, telephoned Respondent to request a quotation for 6,000 tons of standard feed wheat for July delivery. Respondent quoted it at $\$ 60$ per ton FOB Danubian port, which was acceptable to Claimant. The parties agreed to an order of 6,000 tons of standard feed wheat, with the price payable by a letter of credit expiring on 30 August 1998 which provided for no partial shipments.

- 20 February: Mr Harold Stern confirms the terms of agreement reached in the telephone conversation by letter in writing.

- 24 February: Respondent replies to Mr Harold Dean at Food Imports Co ("Imports"), Mr Dean's previous employer, with copy to Claimant confirming the terms of agreement for sale and purchase of standard feed wheat and inquires as to why Mr Dean's letter came from Claimant rather than Imports. 
- 17 April: Government of Danubia mandated an export prohibition due to flooding in the standard feed what producing region of Danubia. Respondent wrote to Mr Dean at both Imports and Claimant to inform him of this.

- 5 May: Respondent wrote to Claimant to inform that the export prohibition in Danubia was replaced with a system of export licences and that Respondent has applied for an export licence accordingly.

- 21 May: Respondent notified by the Ministry of Commerce that it would be permitted to export $80 \%$ of the amount requested. Respondent wrote to Claimant notifying of this outcome and informing Claimant it can only ship out 4,800 tons out of 6,000 agreed. It further noted that it may be able to ship the remaining 1,200 later in the year, in light of which it requested that the agreement is varied by allowing partial shipments in the letter of credit, and extending the letter of credit until 30 November 1998. Claimant responded confirming it will not vary the contract as proposed by Respondent.

- 22 May: Respondent wrote to Claimant confirming its request for amendment and reiterating reasons behind the request.

- 29 May: Respondent received Claimant's letter of credit as per the original agreement. Respondent wrote to Claimant requesting the amendment of terms.

- 16 June: Respondent wrote to Claimant to inform Claimant it will not be supplying it with any standard feed wheat as a result of failure to agree on amendment of terms.

- 27 May: Claimant submits its Request for Arbitration.

\section{H EIGHTH VIS MOOT - Vis water sports equipment}

- Claimant, Sports and More Sports, Inc., is the largest retail seller of athletic equipment of all types in the country of Danubia.

- Respondent, Vis Water Sports Co., is a manufacturer of equipment for water sports.

- 31 March 1999: Claimant received an announcement from Respondent in the mail regarding Respondent's new web site. The parties entered into a negotiation via email and concluded a contract for the purchase of water sports equipment. The purchase was for a list price of $\$ 100,000 \mathrm{FOB}$, with a $5 \%$ discount on the price plus $\$ 7,000$ for transportation, the total price being $\$ 102,000$. 
- 19 May: Goods delivered to Claimant.

- 27 May: Claimant places a second order for more equipment for a list price of $\$ 500,000$.

- 28 May: Respondent accepts Claimant's order and includes an 8\% discount plus transportation costs of $\$ 26,000$, the total price being $\$ 483,000$.

- 19 May - 20 September: Claimant places equipment purchased from Respondent on sale in various of its stores and undertakes a significant marketing campaign using Respondent's slogan "Like a fish in water".

- 20 September: Claimant received a letter from the Vis Fish Company stating that the trademark "Vis" was registered in Danubia by them and that the registration covered all water-related goods and claimed that Claimant was violating their trademark by advertising and selling goods under the name "Vis" and by using the slogan "like a fish in water".

- 4 October: Claimant replied to the Vis Fish Company that it was not violating the trademark since the goods it was selling (sports equipment) could in no way be confused with the Vis Fish Company fish products.

- 15 October: The Vis Fish Company wrote back to Claimant requesting Claimant to stop all sales of "Vis" goods and threatens legal proceedings.

- 28 October: Claimant receives legal advice concerning the likelihood of litigation and potential outcomes of such a dispute.

- 3 November: Claimant informed Respondent of the claim by the Vis Fish Company and avoids the contract, as well as stating it will propose how to make restitution of the unsold goods.

- 10 November: Respondent replied to Claimant stating there is no basis for the avoidance of the contract and refusing to take back unsold goods. It further stated that it would provide assistance with any claim and that it will reimburse Claimant for any legal costs incurred should it suffer an adverse outcome.

- 16 November: Claimant replied to Respondent stating that it will not avoid the contract if Respondent can show that continued sale of its goods in Danubia will not lead to litigation arising out of claims of trademark infringement. No such

- 6 June 2000: Claimant submits its Request for Arbitration. 


\section{I $\quad$ NINTH VIS MOOT - Polyester yarn manufacturing line}

- Claimant, Futura Investment Bank, is an investment bank with interests in numerous countries.

- Respondent, West Equatoriana Bobbins S.A. is a producer of textiles for use in clothing and table linens from natural and synthetic fibres.

- Tailtwist Corp ("Tailtwist") is a non-party entity, a manufacturer of machinery and production processes for the textile trade, some of which were of a type used by Respondent. Tailtwist is currently in insolvency proceedings.

- 1 September 1999: Tailtwist concluded a contract with Respondent for Tailtwist to manufacture and install at Respondent's facilities in Equatoriana a manufacturing line for spinning polyester yarn for the total price of $\$ 9,300,000$ which was to be paid in five instalments. Respondent paid the first instalment on conclusion of contract on 1 September 1999, the second on 6 January 2000 and the third on 20 February 2000. The contract also contains a waiver precluding Respondent from asserting any defences against a future assignee if it did not attempt in good faith to remedy any defective performance.

- 29 March 2000: Tailtwist assigned to Claimant the right to receive fourth and fifth instalments.

- 10 April: A German notification of such assignment is delivered to Respondent with return receipt.

- 15 April: Respondent requested an English translation of the German notification of assignment.

- 19 April: The Vice-President of the Respondent receives English translation of the notification of assignment in the morning. The Vice-President of the Respondent sends a memorandum to its accounts department instructing it not to make any payments to Tailtwist until further notice. Accounts department has already proceeded to make payment to Tailtwist in the afternoon prior to receipt of the memo.

- 20 April: Insolvency proceedings commenced against Tailtwist.

- 16 June: Tailtwist terminates all business activities. 
- 10 January 2001: Respondent claims a reduction in price of $10 \%$ amounting to the fifth instalment on the ground of defective performance.

- 5 June 2001: Claimant submits its Notice of Arbitration to the American Arbitration Association.

\section{J TENTH VIS MOOT-Oriented Polypropylene film}

- Claimant, Equafilm Co., is a producer of polypropylene film used for packaging food products.

- Respondent, Medipack S.A. is a printer and manufacturer of flexible packaging products such as large and small sachets of foodstuffs and the like.

- November 2000: Claimant telephones Respondent and parties enter into discussions about Claimant supplying Respondent with Oriented Polypropylene ("OPP") film used to manufacture packaging products.

- 7 December: Claimant telephones respondent and parties agree on the delivery of 200 tons of opaque white OPP film. Claimant gave Respondent a discount of $8 \%$ from the list price of $\$ 1,800$ per ton on the first order, a substantial discount based on Claimant's expectations of future sales to Respondent. Claimant followed up the telephone conversation by sending Respondent a letter setting out the terms of purchase, including the $8 \%$ discount and a statement that Respondent will "always receive Claimant's best price".

- 15 December: Claimant and Respondent sign the contract for sale and purchase of 200 tons of OPP, being the first order.

- 3 April 2001: Respondent telephones Claimant to place a further order of 1.350 tons of OPP on the terms similar to those as agreed in the first order. Respondent followed up the telephone conversation with a fax setting out the terms of agreement. Claimant, independently from Respondent's fax, sent to Respondent a confirmation form, setting the purchase price at $\$ 2,615,809$.

- 6 April: Respondent sends a fax to Claimant stating the confirmation form contains an error as to price, and the price should include the $8 \%$ discount. 
- 9 April: Claimant replies to Respondent by fax stating it is not offering an $8 \%$ discount on the second order.

- 10 April: Respondent replies to Claimant by fax stating it made the second order in reliance on receiving an $8 \%$ discount.

- 12 April: Claimant replies to Respondent by fax stating the $8 \%$ discount in the first order was only a one-off.

- 27 April: Claimant sends a further fax to Respondent in order to clarify Respondent's intentions.

- 2 May: Respondent replies stating it had returned to Polyfilm GmbH as its supplier for OPP.

- 23 May 2002: Claimant submits its Notice of Arbitration to German Institution of Arbitration.

- Claimant, Equapack Inc., is a corporation in the business of packaging many different types of goods for other companies. A small part of the business has been re-packaging bulk commodities into retail packs for chains of stores who wish to market "own brand" products.

- Respondent, Medi-Machines, S.A. is a manufacturer of machinery, including dry foods packaging equipment.

- 24 June 2002: Claimant writes to Respondent to enquire into the purchase of six machines capable of packaging dry bulk commodities.

- 3 July: Respondent offers six Model 14 auger-feeder dry commodity packaging machines at US\$65,000 per machine.

- 12 July: Claimant accepts Respondent's offer and requests that Respondent arrange shipment of machines to Claimant.

- 23 July: Claimant telephones Respondent to inquire into the status of the order.

- 24 July: Respondent confirms with Claimant via telefax that machines are ready for shipment and will be shipped out later that week. 
- 2 August: Claimant's account debited for the purchase price.

- 21 August: Machines are delivered to Claimant.

- 30 August: Claimant installs the machines and puts them into operation.

- End of September: Four machines used to pack salt show serious signs of corrosion.

- 18 October: Claimant telephones and informs Respondent of the corrosion.

- 19 October: Claimant writes to Respondent to confirm telephone conversation, to confirm the corrosion, to request that Respondent reimburse it the full purchase price plus other related expenses and offers to have the Respondent collect and remove the machines.

- 27 October: Respondent writes to Claimant to offer to sell its Model 17 auger feeders at a substantially reduced price.

- 10 February 2003: Claimant submits its Notice of Arbitration to SIAC.

\section{TWELFTH VIS MOOT-COcoa beans}

- Claimant, Mediterraneo Confectionary Associates, Inc., is a producer of various confectionary items. Claimant uses large quantities of cocoa in the production of its confectionary items, which it then sells throughout Mediterraneo and neighbouring countries.

- Respondent, Equatoriana Commodity Exporters, S.A., is a trader in commodities, including cocoa. It trades in commodities produced both in Equatoriana and other countries.

- 19 November 2001: Respondent telephones Claimant and offers to sell it cocoa. The parties have done business together on a number of occasions and have a longstanding relationship. Claimant and Respondent agree for Respondent to sell and Claimant to buy 400 metric tons of cocoa beans. The parties agreed that, during January-February 2002 Respondent was to set a delivery date, for delivery of cocoa in the months between March - May 2002. The price was set at the current market price and amounted to USD $496,299.55$ for the 400 metric tons. The cocoa contract 1045 was confirmed \& concluded via fax that same day. 
- 24 February 2002: Respondent writes to Claimant to inform it of a storm that hit the cocoa producing area in Equatoriana and of the subsequent ban by the Equatoriana Government Marketing Organization on any export of cocoa at least through the month of March.

- 28 February: The time period for Respondent to fix a delivery date expires.

- 5 March: Claimant writes back to Respondent to inform it still expects Respondent to deliver the cocoa, the source of such cocoa being irrelevant to Claimant.

- 20 March: Equatoriana Government Marketing Organization extends its ban on cocoa exports indefinitely.

- 10 April: Several telephone calls from Claimant are followed by letter requiring that Respondent deliver the cocoa by the end of May 2002.

- 7 May: Respondent informs Claimant by telefax that it will export 100 tons of cocoa to it later that month.

- 18 May: 100 tons of cocoa shipped by Respondent, received and paid for at the contract rate of USD 1.240.75 per metric ton, for a total of USD 124,075.

- 31 May: Delivery period required under the contract expires.

- June-July: Claimant telephones Respondent several times to inquire as to the delivery date of the remaining 300 tons of cocoa.

- 15 August: Claimant wrote to Respondent reiterating that it requires the remaining 300 tons of cocoa to be delivered soon, failing to receive such delivery, Claimant will have to purchase the 300 tons of cocoa from elsewhere and will hold Respondent liable for any extra expenses incurred.

- 29 September: Respondent telephones Claimant and states that there is no indication as to when the Equatoriana Government Marketing Organization may lift the ban on cocoa exports.

- 24 October: Claimant purchased 300 tons of cocoa from Oceania Produce Ltd at the then current market price of USD 2,205.26.

- 25 October: Claimant writes Respondent and notifies it of its purchase from Oceania Produce Ltd. Claimant also notifies Respondent that its claim for excess amount it had to pay will be made subsequently by its legal counsel.

- 11 November: Counsel for Claimant writes to Respondent claiming the excess amount. 
- 12 November: Equatoriana Government Marketing Organization ban on cocoa is rescinded.

13 November: Respondent writes to Claimant stating it would have been prepared to deliver the remaining 300 tons of cocoa. Respondent also asserts that the contract was never terminated by Claimant, and that Claimant's substitute purchase therefore constituted a breach. Respondent asserted it will not pay the excess amount claimed by Claimant of USD $289,353$.

- 15 November: Counsel for Claimant formally avoids the contract.

- 15 November 2002 - July 2004: Parties have entered negotiations in an attempt to reach a settlement but no agreement has been reached.

- 2 July 2004: Claimant submits its request for arbitration to Geneva Chamber of Commerce and Industry.

\section{THIRTEENTH VIS MOOT-Flexoprint machine}

- Claimant, Oceania Printers S.A., is a printing firm.

- Respondent, McHinery Equipment Suppliers Pty, is a seller of new and used industrial equipment.

- 17 April 2002: Claimant inquired with Respondent into the possibility of purchasing a flexoprint machine as advertised on Respondent's website, for printing coated and uncoated papers for wrapping, polyester and also metallic foils for use in the confectionery market and similar fields, with foils of 8 micrometer thickness. Claimant emphasised the urgency with which they would require such a machine.

- 25 April: Respondent replied to Claimant's inquiry and offered a second hand 7 stand Magiprint Flexometix Mark 8 "for your task" and invited Claimant to inspect the machine.

- 6/7 May: Claimant and Respondent met in Athens, Greece, where the machine was situated at the time, to inspect the machine together.

- 10 May: Claimant wrote to Respondent to confirm that the machine was suitable and inform Respondent of its contractual obligations and to emphasise the urgency with which the machine was required. 
- 16 May: Respondent wrote to Claimant to offer to ship the machine directly from Athens and refurbish it at Claimant's premises, in order to accommodate Claimant's request for urgency.

- 21 May: Claimant ordered the machine "as discussed".

- 27 May: Respondent wrote to claimant enclosing the maker's manual for the machine and the contract.

- 30 May: Claimant signed and returned the contract.

- 1 July: The machine arrived, was installed and refurbished. The Respondent's personnel conducted test runs in the following few days.

- 1 August: Claimant wrote to Respondent to indicate its concerns that the machine was creasing and tearing the foil, and the multiple colour runs on the foil were badly out of register, and that despite Respondent's personnel trying to fix the problems, they were unsuccessful. Claimant further pointed out the issues it was having in honouring its contractual obligations to a third party as a result of the machine malfunction, and that the third party was threatening to cancel the contract, which would lead Claimant to suffer significant losses.

- 15 August: Claimant informed Respondent of cancellation of its contract with the third party and requested damages.

- 10 September 2002 - 14 October 2004: Various negotiation attempts between Claimant and Respondent failed.

- 27 June 2005: Claimant submitted its Notice of Arbitration to CIDRA.

- Claimant, Equatoriana Office Space Limited, is a developer of residential and business properties.

- Respondent, Mediterraneo Electrodynamics S.A., is a fabricator and distributor of electrical equipment to the trade.

- 4 May 2005: Claimant sent Respondent a purchase order for five distribution fuse boards to be installed at a new development. Respondent sent a complete but unsigned contract 
to Claimant, specifying that any amendments shall be in writing. The contract enclosed engineering drawings with descriptive notes: "Fuses to be Chat Electronics JP type in accordance with BS88" and "to be lockable to Equalec requirements".

- 12 May: Claimant substituted the arbitration clause in the contract provided and returned it to Respondent, who then signed it.

- 14 July: Respondent's sales manager informed an employee in Claimant's purchasing department that Respondent was at that time unable to deliver JP type fuses, and the parties orally agreed for respondent to deliver JS type fuses.

- 22 August: Respondent delivered JS type fuses to Claimant's building site.

- 24 August: Claimant paid the purchase price.

- 8 September: The local electrical supply distribution company refused to connect the delivered fuse boards to the electrical grid because the fuse boards containing JS type fuses did not meet its standards.

- 9 September: Claimant informed Respondent of the electrical company's refusal to connect the JS type fuses, however respondent was temporarily unable to deliver JP type fuses. Claimant had to make a substitute purchase, the price of which included additional costs.

- 15 August: Claimant submitted a request for arbitration.

\section{O FIFTEENTH VIS MOOT-Blue Hills 2005 wine}

- Claimant, Mediterraneo Wine Cooperative, produces and markets wine from grapes grown by its members. It sells wine both domestically (within Mediterraneo) and for export.

- Respondent, Equatoriana Super Markets S.A., is the largest operator of supermarkets in the country of Equatoriana with about 2,000 outlets. It is also the largest retailer of wine in Equatoriana.

- May 2006: Claimant participated in a trade fair, came across a particular brand of wine named "Blue Hills 2005", and obtained a quote for 20,000 cases from Respondent. 
- 10 June 2006: Respondent sent a purchase order via email and courier corresponding to the quote, which consisted of four shipments, and requested that contract be concluded by a specific date, namely 21 June 2006 .

- 19 June: Respondent sent the signed purchase order by courier to Claimant which arrived on June 21. However, in the afternoon on June 19, claimant received an email from respondent purporting to withdraw the purchase order. This withdrawal was justified by reference to a newspaper article reporting that "anti-freeze" had been added to certain wines from the region in which Blue Hills 2005 was produced. Claimant informed Respondent that these claims were not true, that the wine was safe for consumption and that, given the contract had been concluded, they were ready to make the first shipment. Respondent however refused to honour the contract.

- 18 June 2007: Claimant submitted a request for arbitration.

- CISG Issues: The main and overarching issue in this fact scenario was the validity of the revocation of the offer. The related issue concerned whether the goods were fit for a particular purpose in accordance with article 35.

\section{P SIXTEENTH VIS MOOT-Tera cars}

- Claimant, Mr Joseph Tisk, doing business under the trade name of Reliable Auto Imports is a sole trader car dealer in Mediterraneo. Claimant purchases consignments of new and used cars in foreign countries and imports them for sale in Mediterraneo.

- First Respondent, UAM Distributors Oceania Limited, is a corporation in Oceania and was, until 9 April 2008 when insolvency proceedings were commenced against it, the non-exclusive authorised importer into Oceania of automotive products manufactured by Universal.

- Second Respondent, Universal Auto Manufacturers, S.A. is a corporation in Equatoriana and a major manufacturer of automotive products.

- 18 January 2008: Claimant concluded a contract with First Respondent for sale and purchase of 100 of its new model Tera cars.

- 6 February: First consignment of 25 cars were shipped to Claimant. 
- 18 February: The cars, upon arriving on 11 February, cleared customs and were available to Claimant for collection. As the cars were driven from the port to the showroom they had severe misfiring and were almost undriveable.

- 21 February: Claimant's mechanic inspected ten of the cars and, although he was unable to determine the exact issue, suggested it may be an Engine Control Unit ("ECU") problem.

- 22 February: Claimant telephoned First Respondent to report the issues and followed this up with an email.

- 27 February: First Respondent telephoned and informed Claimant that its personnel could not identify the problem, but considered the ECU was a strong possibility. Second Respondent's chief engineer also telephoned Claimant to confirm this view and was unable to tell Claimant how long the repair or replacement would take, as an examination of the cars would be required first.

- 28 February: Second Respondent telephoned Claimant to confirm it will undertake the repair of the cars. Second Respondent confirmed its personnel can arrive within three days, although some delays may occur if a threatened airport strike in Mediterraneo goes ahead. Second Respondent could not confirm how long it would take for the repairs to be completed.

- 29 February: Claimant notified First and Second Respondents that it was cancelling the contract and requested that First Respondent cancel further shipments and for Second Respondent to cancel sending its personnel to inspect and repair the cars and requested return of the down payment of USD380,000.

- 9 April: First Respondent entered into insolvency proceedings in Oceania.

- 7 May: Claimant shipped the defective cars to Second Respondent.

- 19 June: Second Respondent wrote Claimant stating the retumed cars were repaired.

- 20 June: Claimant wrote to Second Respondent reiterating its request for the return of USD 380,000 and stated that it was unfortunate a guarantee as to repair of the cars could have been provided at the time it was sought as the tone of the previous exchange convinced him he could not count on the cars being repaired in time.

- 15 August 2008: Claimant submits its Request for Arbitration. 
- Claimant, Mediterraneo Engineering Co. provides planning services for urban and rural development and implements those plans as well as those of other companies. It has carried out irrigation projects in Mediterraneo and six other countries.

- Respondent, Equatoriana Super Pumps S.A. is a manufacturer of pumps for agricultural, municipal and industrial water and irrigation systems. It sells to over 50 countries, including Mediterraneo.

- 4 May 2008: Claimant telephoned Respondent to discuss a potential irrigation project it may undertake in Oceania, and that it was considering purchasing water pumps from Respondent as well as collaborating with Respondent on the project in the similar manner as they have done in the past.

- 1 July 2008: Parties concluded a contract for sale by Respondent to Claimant of various water pumps. Contract required the pumps to be delivered to Claimant by 15 December 2008.

- 1 August 2008: Oceania Office of Environmental Health issued a regulation restricting use of beryllium in certain goods, and Claimant notified Respondent of this new regulation immediately.

- 30 October 2008 was the anticipated date of completion of all pumps by Respondent. However, due to the change in regulation in Oceania and subsequent need to procure new steel for some of the pumps ordered, production was completed on 15 November 2008.

- 22 Novem ber 2008: The ship carrying the water pumps to be delivered to Claimant left port for Mediterraneo. 22 December 2008 was the expected arrival date of the ship. Claimant agreed to this as the new delivery date. Claimant paid Respondent in full for the pumps prior to delivery being made.

- 28 November 2008: one day prior to the scheduled date for the ship's crossing of the Isthmus canal on which an accident occurred causing delays in the crossing.

- 1 November - 1 December 2008: Extensive riots in Oceania ending by the government resigning and the military taking over on 1 December.

- 12 December 2008: The ship crossed the canal. 
- 28 December 2008: The military regime in Oceania passed a decree prohibiting import or manufacture of products containing, among other elements, beryllium, with effect from 1 January 2009.

- 5 January 2009: Water Services cancelled the irrigation contract with Claimant on the basis that the water pumps had not been delivered to Oceania as required by the contract. Claimant immediately notified Respondent of this and allegedly avoided the contract for the pumps, requesting the reimbursement of the purchase price and indicating a claim for damages may follow.

- 6 January 2009: The ship arrived in Mediterraneo.

- 15 January 2009: Counsel for Claimant wrote to Respondent avoiding the contract, claiming reimbursement of the purchase price and damages resulting from the cancellation of the contract with Water Services.

- 18 March 2009: Respondent suggested conciliation, which subsequently failed and the arbitration was commenced. 


\section{APPENDIX II}

\section{UNITED NATIONS CONVENTION ON THE INTERNATIONAL SALE OF GOODS 1980}

THE STATES PARTIES TO THIS CONVENTION,

BEARING IN MIND the broad objectives in the resolutions adopted by the sixth special session of the General Assembly of the United Nations on the establishment of a New International Economic Order,

CONSIDERING that the development of international trade on the basis of equality and mutual benefit is an important element in promoting friendly relations among States,

BEING OF THE OPINION that the adoption of uniform rules which govern contracts for the international sale of goods and take into account the different social, economic and legal systems would contribute to the removal of legal barriers in international trade and promote the development of international trade,

HAVE AGREED as follows:

\section{PART I}

\section{SPHERE OF APPLICATION AND GENERAL PROVISIONS}

\section{Chapter I}

\section{SPHERE OF APPLICATION}

\section{A rticle 1}

(1) This Convention applies to contracts of sale of goods between parties whose places of business are in different States:

(a) when the States are Contracting States; or

(b) when the rules of private international law lead to the application of the law of a Contracting State.

(2) The fact that the parties have their places of business in different States is to be disregarded whenever this fact does not appear either from the contract or from any dealings between, or from information disclosed by, the parties at any time before or at the conclusion of the contract. 
(3) Neither the nationality of the parties nor the civil or commercial character of the parties or of the contract is to be taken into consideration in determining the application of this Convention.

\section{Article 2}

This Convention does not apply to sales:

(a) of goods bought for personal, family or household use, unless the seller, at any time before or at the conclusion of the contract, neither knew nor ought to have known that the goods were bought for any such use;

(b) by auction;

(c) on execution or otherwise by authority of law;

(d) of stocks, shares, investment securities, negotiable instruments or money;

(e) of ships, vessels, hovercraft or aircraft;

(f) of electricity.

\section{Article 3}

(1) Contracts for the supply of goods to be manufactured or produced are to be considered sales unless the party who orders the goods undertakes to supply a substantial part of the materials necessary for such manufacture or production.

(2) This Convention does not apply to contracts in which the preponderant part of the obligations of the party who furnishes the goods consists in the supply of labour or other services.

\section{Article 4}

This Convention governs only the formation of the contract of sale and the rights and obligations of the seller and the buyer arising from such a contract. In particular, except as otherwise expressly provided in this Convention, it is not concerned with:

(a) the validity of the contract or of any of its provisions or of any usage;

(b) the effect which the contract may have on the property in the goods sold.

\section{Article 5}


This Convention does not apply to the liability of the seller for death or personal injury caused by the goods to any person.

\section{Article 6}

The parties may exclude the application of this Convention or, subject to article 12 , derogate from or vary the effect of any of its provisions.

\section{Chapter II}

\section{GENERAL PROVISIONS}

\section{Article 7}

(1) In the interpretation of this Convention, regard is to be had to its international character and to the need to promote uniformity in its application and the observance of good faith in international trade.

(2) Questions concerning matters governed by this Convention which are not expressly settled in it are to be settled in conformity with the general principles on which it is based or, in the absence of such principles, in conformity with the law applicable by virtue of the rules of private international law.

\section{A rticle 8}

(1) For the purposes of this Convention statements made by and other conduct of a party are to be interpreted according to his intent where the other party knew or could not have been unaware what that intent was.

(2) If the preceding paragraph is not applicable, statements made by and other conduct of a party are to be interpreted according to the understanding that a reasonable person of the same kind as the other party would have had in the same circumstances.

(3) In determining the intent of a party or the understanding a reasonable person would have had, due consideration is to be given to all relevant circumstances of the case including the negotiations, any practices which the parties have established between themselves, usages and any subsequent conduct of the parties.

\section{Article 9}

(1) The parties are bound by any usage to which they have agreed and by any practices which they have established between themselves. 
(2) The parties are considered, unless otherwise agreed, to have impliedly made applicable to their contract or its formation a usage of which the parties knew or ought to have known and which in international trade is widely known to, and regularly observed by, parties to contracts of the type involved in the particular trade concerned.

\section{Article 10}

For the purposes of this Convention:

(a) if a party has more than one place of business, the place of business is that which has the closest relationship to the contract and its performance, having regard to the circumstances known to or contemplated by the parties at any time before or at the conclusion of the contract;

(b) if a party does not have a place of business, reference is to be made to his habitual residence.

\section{Article 11}

A contract of sale need not be concluded in or evidenced by writing and is not subject to any other requirement as to form. It may be proved by any means, including witnesses.

\section{Article 12}

Any provision of article 11, article 29 or Part II of this Convention that allows a contract of sale or its modification or termination by agreement or any offer, acceptance or other indication of intention to be made in any form other than in writing does not apply where any party has his place of business in a Contracting State which has made a declaration under article 96 of this Convention. The parties may not derogate from or vary the effect or this article.

\section{Article 13}

For the purposes of this Convention "writing" includes telegram and telex.

\section{PART II}

\section{FORMATION OF THE CONTRACT}

\section{Article 14}

(1) A proposal for concluding a contract addressed to one or more specific persons constitutes an offer if it is sufficiently definite and indicates the intention of the offeror to be bound in case of acceptance. A proposal is sufficiently definite if it indicates the goods and expressly or implicitly fixes or makes provision for determining the quantity and the price. 
(2) A proposal other than one addressed to one or more specific persons is to be considered merely as an invitation to make offers, unless the contrary is clearly indicated by the person making the proposal.

\section{Article 15}

(1) An offer becomes effective when it reaches the offeree.

(2) An offer, even if it is irrevocable, may be withdrawn if the withdrawal reaches the offeree before or at the same time as the offer.

\section{Article 16}

(1) Until a contract is concluded an offer may be revoked if the revocation reaches the offeree before he has dispatched an acceptance.

(2) However, an offer cannot be revoked:

(a) if it indicates, whether by stating a fixed time for acceptance or otherwise, that it is irrevocable; or

(b) if it was reasonable for the offeree to rely on the offer as being irrevocable and the offeree has acted in reliance on the offer.

\section{Article 17}

An offer, even if it is irrevocable, is terminated when a rejection reaches the offeror.

\section{Article 18}

(1) A statement made by or other conduct of the offeree indicating assent to an offer is an acceptance. Silence or inactivity does not in itself amount to acceptance.

(2) An acceptance of an offer becomes effective at the moment the indication of assent reaches the offeror. An acceptance is not effective if the indication of assent does not reach the offeror within the time he has fixed or, if no time is fixed, within a reasonable time, due account being taken of the circumstances of the transaction, including the rapidity of the means of communication employed by the offeror. An oral offer must be accepted immediately unless the circumstances indicate otherwise.

(3) However, if, by virtue of the offer or as a result of practices which the parties have established between themselves or of usage, the offeree may indicate assent by performing an act, such as one relating to the dispatch of 
the goods or payment of the price, without notice to the offeror, the acceptance is effective at the moment the act is performed, provided that the act is performed within the period of time laid down in the preceding paragraph.

\section{Article 19}

(1) A reply to an offer which purports to be an acceptance but contains additions, limitations or other modifications is a rejection of the offer and constitutes a counter-offer.

(2) However, a reply to an offer which purports to be an acceptance but contains additional or different terms which do not materially alter the terms of the offer constitutes an acceptance, unless the offeror, without undue delay, objects orally to the discrepancy or dispatches a notice to that effect. If he does not so object, the terms of the contract are the terms of the offer with the modifications contained in the acceptance.

(3) Additional or different terms relating, among other things, to the price, payment, quality and quantity of the goods, place and time of delivery, extent of one party's liability to the other or the settlement of disputes are considered to alter the terms of the offer materially.

\section{Article 20}

(1) A period of time for acceptance fixed by the offeror in a telegram or a letter begins to run from the moment the telegram is handed in for dispatch or from the date shown on the letter or, if no such date is shown, from the date shown on the envelope. A period of time for acceptance fixed by the offeror by telephone, telex or other means of instantaneous communication, begins to run from the moment that the offer reaches the offeree.

(2) Official holidays or non-business days occurring during the period for acceptance are included in calculating the period. However, if a notice of acceptance cannot be delivered at the address of the offeror on the last day of the period because that day falls on an official holiday or a non-business day at the place of business of the offeror, the period is extended until the first business day which follows.

Article 21

(1) A late acceptance is nevertheless effective as an acceptance if without delay the offeror orally so informs the offeree or dispatches a notice to that effect.

(2) If a letter or other writing containing a late acceptance shows that it has been sent in such circumstances that if its transmission had been normal it would have reached the offeror in due time, the late acceptance is effective as an 
acceptance unless, without delay, the offeror orally informs the offeree that he considers his offer as having lapsed or dispatches a notice to that effect.

\title{
Article 22
}

An acceptance may be withdrawn if the withdrawal reaches the offeror before or at the same time as the acceptance would have become effective.

\section{Article 23}

A contract is concluded at the moment when an acceptance of an offer becomes effective in accordance with the provisions of this Convention.

\section{Article 24}

For the purposes of this Part of the Convention, an offer, declaration of acceptance or any other indication of intention "reaches" the addressee when it is made orally to him or delivered by any other means to him personally, to his place of business or mailing address or, if he does not have a place of business or mailing address, to his habitual residence.

\section{PART III}

\section{SALE OF GOODS}

\section{Chapter I}

\section{GENERAL PROVISIONS}

\section{Article 25}

\begin{abstract}
A breach of contract committed by one of the parties is fundamental if it results in such detriment to the other party as substantially to deprive him of what he is entitled to expect under the contract, unless the party in breach did not foresee and a reasonable person of the same kind in the same circumstances would not have foreseen such a result.
\end{abstract}


A declaration of avoidance of the contract is effective only if made by notice to the other party.

\section{Article 27}

Unless otherwise expressly provided in this Part of the Convention, if any notice, request or other communication is given or made by a party in accordance with this Part and by means appropriate in the circumstances, a delay or error in the transmission of the communication or its failure to arrive does not deprive that party of the right to rely on the communication.

\section{Article 28}

If, in accordance with the provisions of this Convention, one party is entitled to require performance of any obligation by the other party, a court is not bound to enter a judgement for specific performance unless the court would do so under its own law in respect of similar contracts of sale not governed by this Convention.

\section{Article 29}

(1) A contract may be modified or terminated by the mere agreement of the parties.

(2) A contract in writing which contains a provision requiring any modification or termination by agreement to be in writing may not be otherwise modified or terminated by agreement. However, a party may be precluded by his conduct from asserting such a provision to the extent that the other party has relied on that conduct.

\section{Chapter II}

\section{OBLIGATIONS OF THE SELLER}

Article 30

The seller must deliver the goods, hand over any documents relating to them and transfer the property in the goods, as required by the contract and this Convention.

\section{Section I. Delivery of the goods and handing over of documents}

\section{Article 31}

If the seller is not bound to deliver the goods at any other particular place, his obligation to deliver consists:

(a) if the contract of sale involves carriage of the goods - in handing the goods over to the first carrier for transmission to the buyer; 
(b) if, in cases not within the preceding subparagraph, the contract relates to specific goods, or unidentified goods to be drawn from a specific stock or to be manufactured or produced, and at the time of the conclusion of the contract the parties knew that the goods were at, or were to be manufactured or produced at, a particular place - in placing the goods at the buyer's disposal at that place;

(c) in other cases - in placing the goods at the buyer's disposal at the place where the seller had his place of business at the time of the conclusion of the contract.

\section{Article 32}

(1) If the seller, in accordance with the contract or this Convention, hands the goods over to a carrier and if the goods are not clearly identified to the contract by markings on the goods, by shipping documents or otherwise, the seller must give the buyer notice of the consignment specifying the goods.

(2) If the seller is bound to arrange for carriage of the goods, he must make such contracts as are necessary for carriage to the place fixed by means of transportation appropriate in the circumstances and according to the usual terms for such transportation.

(3) If the seller is not bound to effect insurance in respect of the carriage of the goods, he must, at the buyer's request, provide him with all available information necessary to enable him to effect such insurance.

\section{Article 33}

The seller must deliver the goods:

(a) if a date is fixed by or determinable from the contract, on that date;

(b) if a period of time is fixed by or determinable from the contract, at any time within that period unless circumstances indicate that the buyer is to choose a date; or

(c) in any other case, within a reasonable time after the conclusion of the contract.

\section{Article 34}

If the seller is bound to hand over documents relating to the goods, he must hand them over at the time and place and in the form required by the contract. If the seller has handed over documents before that time, he may, up to that time, cure any lack of conformity in the documents, if the exercise of this right does not cause the buyer unreasonable inconvenience or unreasonable expense. However, the buyer retains any right to claim damages as provided for in this Convention. 


\section{Section II. Conformity of the goods and third party claims}

\section{Article 35}

(1) The seller must deliver goods which are of the quantity, quality and description required by the contract and which are contained or packaged in the manner required by the contract.

(2) Except where the parties have agreed otherwise, the goods do not conform with the contract unless they:

(a) are fit for the purposes for which goods of the same description would ordinarily be used;

(b) are fit for any particular purpose expressly or impliedly made known to the seller at the time of the conclusion of the contract, except where the circumstances show that the buyer did not rely, or that it was unreasonable for him to rely, on the seller's skill and judgement;

(c) possess the qualities of goods which the seller has held out to the buyer as a sample or model;

(d) are contained or packaged in the manner usual for such goods or, where there is no such manner, in a manner adequate to preserve and protect the goods.

(3) The seller is not liable under subparagraphs (a) to (d) of the preceding paragraph for any lack of conformity of the goods if at the time of the conclusion of the contract the buyer knew or could not have been unaware of such lack of conformity.

\section{Article 36}

(1) The seller is liable in accordance with the contract and this Convention for any lack of conformity which exists at the time when the risk passes to the buyer, even though the lack of conformity becomes apparent only after that time.

(2) The seller is also liable for any lack of conformity which occurs after the time indicated in the preceding paragraph and which is due to a breach of any of his obligations, including a breach of any guarantee that for a period of time the goods will remain fit for their ordinary purpose or for some particular purpose or will retain specified qualities or characteristics. 


\section{Article 37}

If the seller has delivered goods before the date for delivery, he may, up to that date, deliver any missing part or make up any deficiency in the quantity of the goods delivered, or deliver goods in replacement of any nonconforming goods delivered or remedy any lack of conformity in the goods delivered, provided that the exercise of this right does not cause the buyer unreasonable inconvenience or unreasonable expense. However, the buyer retains any right to claim damages as provided for in this Convention.

\section{Article 38}

(1) The buyer must examine the goods, or cause them to be examined, within as short a period as is practicable in the circumstances.

(2) If the contract involves carriage of the goods, examination may be deferred until after the goods have arrived at their destination.

(3) If the goods are redirected in transit or redispatched by the buyer without a reasonable opportunity for examination by him and at the time of the conclusion of the contract the seller knew or ought to have known of the possibility of such redirection or redispatch, examination may be deferred until after the goods have arrived at the new destination.

\section{Article 39}

(1) The buyer loses the right to rely on a lack of conformity of the goods if he does not give notice to the seller specifying the nature of the lack of conformity within a reasonable time after he has discovered it or ought to have discovered it.

(2) In any event, the buyer loses the right to rely on a lack of conformity of the goods if he does not give the seller notice thereof at the latest within a period of two years from the date on which the goods were actually handed over to the buyer, unless this time-limit is inconsistent with a contractual period of guarantee.

\section{Article 40}

The seller is not entitled to rely on the provisions of articles 38 and 39 if the lack of conformity relates to facts of which he knew or could not have been unaware and which he did not disclose to the buyer.

\section{Article 41}


The seller must deliver goods which are free from any right or claim of a third party, unless the buyer agreed to take the goods subject to that right or claim. However, if such right or claim is based on industrial property or other intellectual property, the seller's obligation is governed by article 42 .

\section{Article 42}

(1) The seller must deliver goods which are free from any right or claim of a third party based on industrial property or other intellectual property, of which at the time of the conclusion of the contract the seller knew or could not have been unaware, provided that the right or claim is based on industrial property or other intellectual property:

(a) under the law of the State where the goods will be resold or otherwise used, if it was contemplated by the parties at the time of the conclusion of the contract that the goods would be resold or otherwise used in that State; or

(b) in any other case, under the law of the State where the buyer has his place of business.

(2) The obligation of the seller under the preceding paragraph does not extend to cases where:

(a) at the time of the conclusion of the contract the buyer knew or could not have been unaware of the right or claim; or

(b) the right or claim results from the seller's compliance with technical drawings, designs, formulae or other such specifications furnished by the buyer.

\section{Article 43}

(1) The buyer loses the right to rely on the provisions of article 41 or article 42 if he does not give notice to the seller specifying the nature of the right or claim of the third party within a reasonable time after he has become aware or ought to have become aware of the right or claim.

(2) The seller is not entitled to rely on the provisions of the preceding paragraph if he knew of the right or claim of the third party and the nature of it.

\section{Article 44}


Notwithstanding the provisions of paragraph (1) of article 39 and paragraph (1) of article 43, the buyer may reduce the price in accordance with article 50 or claim damages, except for loss of profit, if he has a reasonable excuse for his failure to give the required notice.

\section{Section III. Remedies for breach of contract by the seller}

\section{Article 45}

(1) If the seller fails to perform any of his obligations under the contract or this Convention, the buyer may:

(a) exercise the rights provided in articles 46 to 52 ;

(b) claim damages as provided in articles 74 to 77 .

(2) The buyer is not deprived of any right he may have to claim damages by exercising his right to other remedies.

(3) No period of grace may be granted to the seller by a court or arbitral tribunal when the buyer resorts to a remedy for breach of contract.

\section{Article 46}

(1) The buyer may require performance by the seller of his obligations unless the buyer has resorted to a remedy which is inconsistent with this requirement.

(2) If the goods do not conform with the contract, the buyer may require delivery of substitute goods only if the lack of conformity constitutes a fundamental breach of contract and a request for substitute goods is made either in conjunction with notice given under article 39 or within a reasonable time thereafter.

(3) If the goods do not conform with the contract, the buyer may require the seller to remedy the lack of conformity by repair, unless this is unreasonable having regard to all the circumstances. A request for repair must be made either in conjunction with notice given under article 39 or within a reasonable time thereafter.

\section{Article 47}

(1) The buyer may fix an additional period of time of reasonable length for performance by the seller of his obligations.

(2) Unless the buyer has received notice from the seller that he will not perform within the period so fixed, the buyer may not, during that period, resort to any remedy for breach of contract. However, the buyer is not deprived thereby of any right he may have to claim damages for delay in performance. 


\section{Article 48}

(1) Subject to article 49, the seller may, even after the date for delivery, remedy at his own expense any failure to perform his obligations, if he can do so without unreasonable delay and without causing the buyer unreasonable inconvenience or uncertainty of reimbursement by the seller of expenses advanced by the buyer. However, the buyer retains any right to claim damages as provided for in this Convention.

(2) If the seller requests the buyer to make known whether he will accept performance and the buyer does not comply with the request within a reasonable time, the seller may perform within the time indicated in his request. The buyer may not, during that period of time, resort to any remedy which is inconsistent with performance by the seller.

(3) A notice by the seller that he will perform within a specified period of time is assumed to include a request, under the preceding paragraph, that the buyer make known his decision.

(4) A request or notice by the seller under paragraph (2) or (3) of this article is not effective unless received by the buyer.

\section{Article 49}

(1) The buyer may declare the contract avoided:

(a) if the failure by the seller to perform any of his obligations under the contract or this Convention amounts to a fundamental breach of contract; or

(b) in case of non-delivery, if the seller does not deliver the goods within the additional period of time fixed by the buyer in accordance with paragraph (1) of article 47 or declares that he will not deliver within the period so fixed.

(2) However, in cases where the seller has delivered the goods, the buyer loses the right to declare the contract avoided unless he does so:

(a) in respect of late delivery, within a reasonable time after he has become aware that delivery has been made;

(b) in respect of any breach other than late delivery, within a reasonable time:

(i) after he knew or ought to have known of the breach;

(ii) after the expiration of any additional period of time fixed by the buyer in accordance with paragraph (1) of article 47 , or after the seller has declared that he will not perform his obligations within such an additional period; or 
(iii) after the expiration of any additional period of time indicated by the seller in accordance with paragraph (2) of article 48 , or after the buyer has declared that he will not accept performance.

\section{Article 50}

If the goods do not conform with the contract and whether or not the price has already been paid, the buyer may reduce the price in the same proportion as the value that the goods actually delivered had at the time of the delivery bears to the value that conforming goods would have had at that time. However, if the seller remedies any failure to perform his obligations in accordance with article 37 or article 48 or if the buyer refuses to accept performance by the seller in accordance with those articles, the buyer may not reduce the price.

\section{Article 51}

(1) If the seller delivers only a part of the goods or if only a part of the goods delivered is in conformity with the contract, articles 46 to 50 apply in respect of the part which is missing or which does not conform.

(2) The buyer may declare the contract avoided in its entirety only if the failure to make delivery completely or in conformity with the contract amounts to a fundamental breach of the contract.

\section{Article 52}

(1) If the seller delivers the goods before the date fixed, the buyer may take delivery or refuse to take delivery.

(2) If the seller delivers a quantity of goods greater than that provided for in the contract, the buyer may take delivery or refuse to take delivery of the excess quantity. If the buyer takes delivery of all or part of the excess quantity, he must pay for it at the contract rate.

\section{Chapter III}

\section{OBLIGATIONS OF THE BUYER}

\section{Article 53}

The buyer must pay the price for the goods and take delivery of them as required by the contract and this Convention.

\section{Section I. Payment of the price}

\section{Article 54}


The buyer's obligation to pay the price includes taking such steps and complying with such formalities as may be required under the contract or any laws and regulations to enable payment to be made.

\section{Article 55}

Where a contract has been validly concluded but does not expressly or implicitly fix or make provision for determining the price, the parties are considered, in the absence of any indication to the contrary, to have impliedly made reference to the price generally charged at the time of the conclusion of the contract for such goods sold under comparable circumstances in the trade concerned.

\section{Article 56}

If the price is fixed according to the weight of the goods, in case of doubt it is to be determined by the net weight.

\section{Article 57}

(1) If the buyer is not bound to pay the price at any other particular place, he must pay it to the seller:

(a) at the seller's place of business; or

(b) if the payment is to be made against the handing over of the goods or of documents, at the place where the handing over takes place.

(2) The seller must bear any increases in the expenses incidental to payment which is caused by a change in his place of business subsequent to the conclusion of the contract.

\section{Article 58}

(1) If the buyer is not bound to pay the price at any other specific time, he must pay it when the seller places either the goods or documents controlling their disposition at the buyer's disposal in accordance with the contract and this Convention. The seller may make such payment a condition for handing over the goods or documents.

(2) If the contract involves carriage of the goods, the seller may dispatch the goods on terms whereby the goods, or documents controlling their disposition, will not be handed over to the buyer except against payment of the price.

(3) The buyer is not bound to pay the price until he has had an opportunity to examine the goods, unless the procedures for delivery or payment agreed upon by the parties are inconsistent with his having such an opportunity. 
The buyer must pay the price on the date fixed by or determinable from the contract and this Convention without the need for any request or compliance with any formality on the part of the seller.

\section{Section II. Taking delivery}

\section{Article 60}

The buyer's obligation to take delivery consists:

(a) in doing all the acts which could reasonably be expected of him in order to enable the seller to make delivery; and

(b) in taking over the goods.

\section{Section III. Remedies for breach of contract by the buyer}

\section{Article 61}

(1) If the buyer fails to perform any of his obligations under the contract or this Convention, the seller may:

(a) exercise the rights provided in articles 62 to 65 ;

(b) claim damages as provided in articles 74 to 77 .

(2) The seller is not deprived of any right he may have to claim damages by exercising his right to other remedies.

(3) No period of grace may be granted to the buyer by a court or arbitral tribunal when the seller resorts to a remedy for breach of contract.

\section{Article 62}

The seller may require the buyer to pay the price, take delivery or perform his other obligations, unless the seller has resorted to a remedy which is inconsistent with this requirement.

\section{Article 63}


(1) The seller may fix an additional period of time of reasonable length for performance by the buyer of his obligations.

(2) Unless the seller has received notice from the buyer that he will not perform within the period so fixed, the seller may not, during that period, resort to any remedy for breach of contract. However, the seller is not deprived thereby of any right he may have to claim damages for delay in performance.

\section{Article 64}

(1) The seller may declare the contract avoided:

(a) if the failure by the buyer to perform any of his obligations under the contract or this Convention amounts to a fundamental breach of contract; or

(b) if the buyer does not, within the additional period of time fixed by the seller in accordance with paragraph (1) of article 63, perform his obligation to pay the price or take delivery of the goods, or if he declares that he will not do so within the period so fixed.

(2) However, in cases where the buyer has paid the price, the seller loses the right to declare the contract avoided unless he does so:

(a) in respect of late performance by the buyer, before the seller has become aware that performance has been rendered; or

(b) in respect of any breach other than late performance by the buyer, within a reasonable time:

(i) after the seller knew or ought to have known of the breach; or

(ii) after the expiration of any additional period of time fixed by the seller in accordance with paragraph (1) of article 63 , or after the buyer has declared that he will not perform his obligations within such an additional period.

\section{Article 65}

(1) If under the contract the buyer is to specify the form, measurement or other features of the goods and he fails to make such specification either on the date agreed upon or within a reasonable time after receipt of a request from the seller, the seller may, without prejudice to any other rights he may have, make the specification himself in accordance with the requirements of the buyer that may be known to him. 
(2) If the seller makes the specification himself, he must inform the buyer of the details thereof and must fix a reasonable time within which the buyer may make a different specification. If, after receipt of such a communication, the buyer fails to do so within the time so fixed, the specification made by the seller is binding.

\section{Chapter IV}

\section{PASSING OF RISK}

\section{Article 66}

Loss of or damage to the goods after the risk has passed to the buyer does not discharge him from his obligation to pay the price, unless the loss or damage is due to an act or omission of the seller.

\section{Article 67}

(1) If the contract of sale involves carriage of the goods and the seller is not bound to hand them over at a particular place, the risk passes to the buyer when the goods are handed over to the first carrier for transmission to the buyer in accordance with the contract of sale. If the seller is bound to hand the goods over to a carrier at a particular place, the risk does not pass to the buyer until the goods are handed over to the carrier at that place. The fact that the seller is authorized to retain documents controlling the disposition of the goods does not affect the passage of the risk.

(2) Nevertheless, the risk does not pass to the buyer until the goods are clearly identified to the contract, whether by markings on the goods, by shipping documents, by notice given to the buyer or otherwise.

\section{Article 68}

The risk in respect of goods sold in transit passes to the buyer from the time of the conclusion of the contract. However, if the circumstances so indicate, the risk is assumed by the buyer from the time the goods were handed over to the carrier who issued the documents embodying the contract of carriage. Nevertheless, if at the time of the conclusion of the contract of sale the seller knew or ought to have known that the goods had been lost or damaged and did not disclose this to the buyer, the loss or damage is at the risk of the seller.

\section{Article 69}

(1) In cases not within articles 67 and 68, the risk passes to the buyer when he takes over the goods or, if he does not do so in due time, from the time when the goods are placed at his disposal and he commits a breach of contract by failing to take delivery. 
(2) However, if the buyer is bound to take over the goods at a place other than a place of business of the seller, the risk passes when delivery is due and the buyer is aware of the fact that the goods are placed at his disposal at that place.

(3) If the contract relates to goods not then identified, the goods are considered not to be placed at the disposal of the buyer until they are clearly identified to the contract.

\section{Article 70}

If the seller has committed a fundamental breach of contract, articles 67,68 and 69 do not impair the remedies available to the buyer on account of the breach.

\section{Chapter V}

\section{PROVISIONS COMMON TO THE OBLIGATIONS OF THE SELLER AND OF THE BUYER}

\section{Section I. Anticipatory breach and instalment contracts}

\section{Article 71}

(1) A party may suspend the performance of his obligations if, after the conclusion of the contract, it becomes apparent that the other party will not perform a substantial part of his obligations as a result of:

(a) a serious deficiency in his ability to perform or in his creditworthiness; or

(b) his conduct in preparing to perform or in performing the contract.

(2) If the seller has already dispatched the goods before the grounds described in the preceding paragraph become evident, he may prevent the handing over of the goods to the buyer even though the buyer holds a document which entitles him to obtain them. The present paragraph relates only to the rights in the goods as between the buyer and the seller.

(3) A party suspending performance, whether before or after dispatch of the goods, must immediately give notice of the suspension to the other party and must continue with performance if the other party provides adequate assurance of his performance.

\section{Article 72}

(1) If prior to the date for performance of the contract it is clear that one of the parties will commit a fundamental breach of contract, the other party may declare the contract avoided. 
(2) If time allows, the party intending to declare the contract avoided must give reasonable notice to the other party in order to permit him to provide adequate assurance of his performance.

(3) The requirements of the preceding paragraph do not apply if the other party has declared that he will not perform his obligations.

\section{Article 73}

(1) In the case of a contract for delivery of goods by instalments, if the failure of one party to perform any of his obligations in respect of any instalment constitutes a fundamental breach of contract with respect to that instalment, the other party may declare the contract avoided with respect to that instalment.

(2) If one party's failure to perform any of his obligations in respect of any instalment gives the other party good grounds to conclude that a fundamental breach of contract will occur with respect to future instalments, he may declare the contract avoided for the future, provided that he does so within a reasonable time.

(3) A buyer who declares the contract avoided in respect of any delivery may, at the same time, declare it avoided in respect of deliveries already made or of future deliveries if, by reason of their interdependence, those deliveries could not be used for the purpose contemplated by the parties at the time of the conclusion of the contract.

\section{Section II. Damages}

\section{Article 74}

Damages for breach of contract by one party consist of a sum equal to the loss, including loss of profit, suffered by the other party as a consequence of the breach. Such damages may not exceed the loss which the party in breach foresaw or ought to have foreseen at the time of the conclusion of the contract, in the light of the facts and matters of which he then knew or ought to have known, as a possible consequence of the breach of contract.

\section{Article 75}

If the contract is avoided and if, in a reasonable manner and within a reasonable time after avoidance, the buyer has bought goods in replacement or the seller has resold the goods, the party claiming damages may recover the difference between the contract price and the price in the substitute transaction as well as any further damages recoverable under article 74.

\section{Article 76}

(1) If the contract is avoided and there is a current price for the goods, the party claiming damages may, if he has not made a purchase or resale under article 75 , recover the difference between the price fixed by the contract and the 
current price at the time of avoidance as well as any further damages recoverable under article 74 . If, however, the party claiming damages has avoided the contract after taking over the goods, the current price at the time of such taking over shall be applied instead of the current price at the time of avoidance.

(2) For the purposes of the preceding paragraph, the current price is the price prevailing at the place where delivery of the goods should have been made or, if there is no current price at that place, the price at such other place as serves as a reasonable substitute, making due allowance for differences in the cost of transporting the goods.

\section{Article 77}

A party who relies on a breach of contract must take such measures as are reasonable in the circumstances to mitigate the loss, including loss of profit, resulting from the breach. If he fails to take such measures, the party in breach may claim a reduction in the damages in the amount by which the loss should have been mitigated.

\section{Section III. Interest}

\section{Article 78}

If a party fails to pay the price or any other sum that is in arrears, the other party is entitled to interest on it, without prejudice to any claim for damages recoverable under article 74 .

\section{Section IV. Exemptions}

\section{Article 79}

(1) A party is not liable for a failure to perform any of his obligations if he proves that the failure was due to an impediment beyond his control and that he could not reasonably be expected to have taken the impediment into account at the time of the conclusion of the contract or to have avoided or overcome it or its consequences.

(2) If the party's failure is due to the failure by a third person whom he has engaged to perform the whole or a part of the contract, that party is exempt from liability only if:

(a) he is exempt under the preceding paragraph; and

(b) the person whom he has so engaged would be so exempt if the provisions of that paragraph were applied to him. 
(3) The exemption provided by this article has effect for the period during which the impediment exists.

(4) The party who fails to perform must give notice to the other party of the impediment and its effect on his ability to perform. If the notice is not received by the other party within a reasonable time after the party who fails to perform knew or ought to have known of the impediment, he is liable for damages resulting from such non-receipt.

(5) Nothing in this article prevents either party from exercising any right other than to claim damages under this Convention.

\section{Article 80}

A party may not rely on a failure of the other party to perform, to the extent that such failure was caused by the first party's act or omission.

\section{Section V. Effects of avoidance}

\section{Article 81}

(1) Avoidance of the contract releases both parties from their obligations under it, subject to any damages which may be due. Avoidance does not affect any provision of the contract for the settlement of disputes or any other provision of the contract governing the rights and obligations of the parties consequent upon the avoidance of the contract.

(2) A party who has performed the contract either wholly or in part may claim restitution from the other party of whatever the first party has supplied or paid under the contract. If both parties are bound to make restitution, they must do so concurrently.

\section{Article 82}

(1) The buyer loses the right to declare the contract avoided or to require the seller to deliver substitute goods if it is impossible for him to make restitution of the goods substantially in the condition in which he received them.

(2) The preceding paragraph does not apply:

(a) if the impossibility of making restitution of the goods or of making restitution of the goods substantially in the condition in which the buyer received them is not due to his act or omission; 
(b) if the goods or part of the goods have perished or deteriorated as a result of the examination provided for in article 38 ; or

(c) if the goods or part of the goods have been sold in the normal course of business or have been consumed or transformed by the buyer in the course of normal use before he discovered or ought to have discovered the lack of conformity.

\section{Article 83}

A buyer who has lost the right to declare the contract avoided or to require the seller to deliver substitute goods in accordance with article 82 retains all other remedies under the contract and this Convention.

\section{Article 84}

(1) If the seller is bound to refund the price, he must also pay interest on it, from the date on which the price was paid.

(2) The buyer must account to the seller for all benefits which he has derived from the goods or part of them:

(a) if he must make restitution of the goods or part of them; or

(b) if it is impossible for him to make restitution of all or part of the goods or to make restitution of all or part of the goods substantially in the condition in which he received them, but he has nevertheless declared the contract avoided or required the seller to deliver substitute goods.

\section{Section VI. Preservation of the goods}

\section{Article 85}

If the buyer is in delay in taking delivery of the goods or, where payment of the price and delivery of the goods are to be made concurrently, if he fails to pay the price, and the seller is either in possession of the goods or otherwise able to control their disposition, the seller must take such steps as are reasonable in the circumstances to preserve them. He is entitled to retain them until he has been reimbursed his reasonable expenses by the buyer.

\section{Article 86}

(1) If the buyer has received the goods and intends to exercise any right under the contract or this Convention to reject them, he must take such steps to preserve them as are reasonable in the circumstances. He is entitled to retain them until he has been reimbursed his reasonable expenses by the seller. 
(2) If goods dispatched to the buyer have been placed at his disposal at their destination and he exercises the right to reject them, he must take possession of them on behalf of the seller, provided that this can be done without payment of the price and without unreasonable inconvenience or unreasonable expense. This provision does not apply if the seller or a person authorized to take charge of the goods on his behalf is present at the destination. If the buyer takes possession of the goods under this paragraph, his rights and obligations are governed by the preceding paragraph.

\section{Article 87}

A party who is bound to take steps to preserve the goods may deposit them in a warehouse of a third person at the expense of the other party provided that the expense incurred is not unreasonable.

\section{Article 88}

(1) A party who is bound to preserve the goods in accordance with article 85 or 86 may sell them by any appropriate means if there has been an unreasonable delay by the other party in taking possession of the goods or in taking them back or in paying the price or the cost of preservation, provided that reasonable notice of the intention to sell has been given to the other party.

(2) If the goods are subject to rapid deterioration or their preservation would involve unreasonable expense, a party who is bound to preserve the goods in accordance with article 85 or 86 must take reasonable measures to sell them. To the extent possible he must give notice to the other party of his intention to sell.

(3) A party selling the goods has the right to retain out of the proceeds of sale an amount equal to the reasonable expenses of preserving the goods and of selling them. He must account to the other party for the balance.

\section{PART IV}

\section{FINAL PROVISIONS}

\section{Article 89}

The Secretary-General of the United Nations is hereby designated as the depositary for this Convention.

\section{Article 90}

This Convention does not prevail over any international agreement which has already been or may be entered into and which contains provisions concerning the matters governed by this Convention, provided that the parties have their places of business in States parties to such agreement. 


\section{Article 91}

(1) This Convention is open for signature at the concluding meeting of the United Nations Conference on Contracts for the International Sale of Goods and will remain open for signature by all States at the Headquarters of the United Nations, New York until 30 September 1981.

(2) This Convention is subject to ratification, acceptance or approval by the signatory States.

(3) This Convention is open for accession by all States which are not signatory States as from the date it is open for signature.

(4) Instruments of ratification, acceptance, approval and accession are to be deposited with the Secretary-General of the United Nations.

\section{Article 92}

(1) A Contracting State may declare at the time of signature, ratification, acceptance, approval or accession that it will not be bound by Part II of this Convention or that it will not be bound by Part III of this Convention.

(2) A Contracting State which makes a declaration in accordance with the preceding paragraph in respect of Part II or Part III of this Convention is not to be considered a Contracting State within paragraph (1) of article 1 of this Convention in respect of matters governed by the Part to which the declaration applies.

\section{Article 93}

(1) If a Contracting State has two or more territorial units in which, according to its constitution, different systems of law are applicable in relation to the matters dealt with in this Convention, it may, at the time of signature, ratification, acceptance, approval or accession, declare that this Convention is to extend to all its territorial units or only to one or more of them, and may amend its declaration by submitting another declaration at any time.

(2) These declarations are to be notified to the depositary and are to state expressly the territorial units to which the Convention extends.

(3) If, by virtue of a declaration under this article, this Convention extends to one or more but not all of the territorial units of a Contracting State, and if the place of business of a party is located in that State, this place of business, for the purposes of this Convention, is considered not to be in a Contracting State, unless it is in a territorial unit to which the Convention extends.

(4) If a Contracting State makes no declaration under paragraph (1) of this article, the Convention is to extend to all territorial units of that State. 


\section{Article 94}

(1) Two or more Contracting States which have the same or closely related legal rules on matters governed by this Convention may at any time declare that the Convention is not to apply to contracts of sale or to their formation where the parties have their places of business in those States. Such declarations may be made jointly or by reciprocal unilateral declarations.

(2) A Contracting State which has the same or closely related legal rules on matters governed by this Convention as one or more non-Contracting States may at any time declare that the Convention is not to apply to contracts of sale or to their formation where the parties have their places of business in those States.

(3) If a State which is the object of a declaration under the preceding paragraph subsequently becomes a Contracting State, the declaration made will, as from the date on which the Convention enters into force in respect of the new Contracting State, have the effect of a declaration made under paragraph (1), provided that the new Contracting State joins in such declaration or makes a reciprocal unilateral declaration.

\section{Article 95}

Any State may declare at the time of the deposit of its instrument of ratification, acceptance, approval or accession that it will not be bound by subparagraph (1)(b) of article 1 of this Convention.

\section{Article 96}

A Contracting State whose legislation requires contracts of sale to be concluded in or evidenced by writing may at any time make a declaration in accordance with article 12 that any provision of article 11, article 29, or Part II of this Convention, that allows a contract of sale or its modification or termination by agreement or any offer, acceptance, or other indication of intention to be made in any form other than in writing, does not apply where any party has his place of business in that State.

\section{Article 97}

(1) Declarations made under this Convention at the time of signature are subject to confirmation upon ratification, acceptance or approval.

(2) Declarations and confirmations of declarations are to be in writing and be formally notified to the depositary.

(3) A declaration takes effect simultaneously with the entry into force of this Convention in respect of the State concerned. However, a declaration of which the depositary receives formal notification after such entry into force takes effect on the first day of the month following the expiration of six months after the date of its receipt by the 
depositary. Reciprocal unilateral declarations under article 94 take effect on the first day of the month following the expiration of six months after the receipt of the latest declaration by the depositary.

(4) Any State which makes a declaration under this Convention may withdraw it at any time by a formal notification in writing addressed to the depositary. Such withdrawal is to take effect on the first day of the month following the expiration of six months after the date of the receipt of the notification by the depositary.

(5) A withdrawal of a declaration made under article 94 renders inoperative, as from the date on which the withdrawal takes effect, any reciprocal declaration made by another State under that article.

\section{Article 98}

No reservations are permitted except those expressly authorized in this Convention.

\section{Article 99}

(1) This Convention enters into force, subject to the provisions of paragraph (6) of this article, on the first day of the month following the expiration of twelve months after the date of deposit of the tenth instrument of ratification, acceptance, approval or accession, including an instrument which contains a declaration made under article 92.

(2) When a State ratifies, accepts, approves or accedes to this Convention after the deposit of the tenth instrument of ratification, acceptance, approval or accession, this Convention, with the exception of the Part excluded, enters into force in respect of that State, subject to the provisions of paragraph (6) of this article, on the first day of the month following the expiration of twelve months after the date of the deposit of its instrument of ratification, acceptance, approval or accession.

(3) A State which ratifies, accepts, approves or accedes to this Convention and is a party to either or both the Convention relating to a Uniform Law on the Formation of Contracts for the International Sale of Goods done at The Hague on 1 July 1964 (1964 Hague Formation Convention) and the Convention relating to a Uniform Law on the International Sale of Goods done at The Hague on 1 July 1964 (1964 Hague Sales Convention) shall at the same time denounce, as the case may be, either or both the 1964 Hague Sales Convention and the 1964 Hague Formation Convention by notifying the Government of the Netherlands to that effect.

(4) A State party to the 1964 Hague Sales Convention which ratifies, accepts, approves or accedes to the present Convention and declares or has declared under article 52 that it will not be bound by Part II of this Convention shall at the time of ratification, acceptance, approval or accession denounce the 1964 Hague Sales Convention by notifying the Government of the Netherlands to that effect. 
(5) A State party to the 1964 Hague Formation Convention which ratifies, accepts, approves or accedes to the present Convention and declares or has declared under article 92 that it will not be bound by Part III of this Convention shall at the time of ratification, acceptance, approval or accession denounce the 1964 Hague Formation Convention by notifying the Government of the Netherlands to that effect.

(6) For the purpose of this article, ratifications, acceptances, approvals and accessions in respect of this Convention by States parties to the 1964 Hague Formation Convention or to the 1964 Hague Sales Convention shall not be effective until such denunciations as may be required on the part of those States in respect of the latter two Conventions have themselves become effective. The depositary of this Convention shall consult with the Government of the Netherlands, as the depositary of the 1964 Conventions, so as to ensure necessary co-ordination in this respect.

\section{Article 100}

(1) This Convention applies to the formation of a contract only when the proposal for concluding the contract is made on or after the date when the Convention enters into force in respect of the Contracting States referred to in subparagraph (1)(a) or the Contracting State referred to in subparagraph (1)(b) of article 1.

(2) This Convention applies only to contracts concluded on or after the date when the Convention enters into force in respect of the Contracting States referred to in subparagraph (1)(a) or the Contracting State referred to in subparagraph (1)(b) of article 1 .

\section{Article 101}

(1) A Contracting State may denounce this Convention, or Part II or Part III of the Convention, by a formal notification in writing addressed to the depositary.

(2) The denunciation takes effect on the first day of the month following the expiration of twelve months after the notification is received by the depositary. Where a longer period for the denunciation to take effect is specified in the notification, the denunciation takes effect upon the expiration of such longer period after the notification is received by the depositary.

DONE at Vienna, this day of eleventh day of April, one thousand nine hundred and eighty, in a single original, of which the Arabic, Chinese, English, French, Russian and Spanish texts are equally authentic.

IN WITNESS WHEREOF the undersigned plenipotentiaries, being duly authorized by their respective Governments, have signed this Convention. 